Asymmetries in Price-Setting Behavoir: New Microeconometric from Switzerland

Bo E. Honoré, Daniel Kaufmann and Sarah Lein

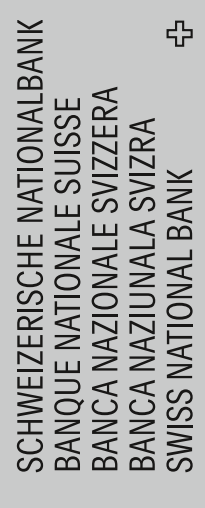


The views expressed in this paper are those of the author(s) and do not necessarily represent those of the Swiss National Bank. Working Papers describe research in progress. Their aim is to elicit comments and to further debate.

\section{Copyright $\odot$}

The Swiss National Bank (SNB) respects all third-party rights, in particular rights relating to works protected by copyright (information or data, wordings and depictions, to the extent that these are of an individual character). SNB publications containing a reference to a copyright ( $\odot$ Swiss National Bank/SNB, Zurich/year, or similar) may, under copyright law, only be used (reproduced, used via the internet, etc.) for non-commercial purposes and provided that the source is mentioned. Their use for commercial purposes is only permitted with the prior express consent of the SNB.

General information and data published without reference to a copyright may be used without mentioning the source.

To the extent that the information and data clearly derive from outside sources, the users of such information and data are obliged to respect any existing copyrights and to obtain the right of use from the relevant outside source themselves.

\section{Limitation of liability}

The SNB accepts no responsibility for any information it provides. Under no circumstances will it accept any liability for losses or damage which may result from the use of such information. This limitation of liability applies, in particular, to the topicality, accuracy, validity and availability of the information.

ISSN 1660-7716 (printed version)

ISSN 1660-7724 (online version)

๑ 2012 by Swiss National Bank, Börsenstrasse 15, P.0. Box, CH-8022 Zurich 


\title{
Asymmetries in Price-Setting Behavior: New Microeconometric Evidence from Switzerland*
}

\author{
Bo E. Honoréł Daniel Kaufmann ${ }^{\ddagger}$ and Sarah Lein ${ }^{\S}$
}

June 11, 2012

\begin{abstract}
In this paper we follow the recent empirical literature that has specified reduced-form models for price setting that are closely tied to $(S, s)$-pricing rules. Our contribution to the literature is twofold. First, we propose an estimator that relaxes distributional assumptions on the unobserved heterogeneity. Second, we use the estimator to examine asymmetries in price-setting behavior. Using micro price data underlying the Swiss CPI we find that a substantial share of asymmetries in the frequency of price changes can be traced back to a rising aggregate price level. We show that asymmetries would be reduced substantially in the absence of aggregate inflation.
\end{abstract}

JEL classification: E31, E4, E5, C3, C23

Keywords: Asymmetric price setting, downward nominal price rigidity, front loading, menu-cost model, heterogeneity, CPI micro data, panel data

\footnotetext{
${ }^{*}$ This paper was prepared for the JMCB-SNB-UniBern Conference 2011 at the Study Center Gerzensee. We would like to thank our discussant Raf Wouters, two anonymous referees and the conference participants for helpful discussions and suggestions. We are also grateful to Thomas Moser, Barbara Rudolf and seminar participants at the SNB, the Bundesbank, the University of Heidelberg, the University of Bern and the SSES annual meeting for their comments. Bo Honoré gratefully acknowledges financial support from the National Science Foundation. The views expressed in this paper are those of the authors and not necessarily those of the Swiss National Bank.

${ }^{\dagger}$ Department of Economics, Princeton University, Princeton, NJ 08544. E-mail: honore@princeton.edu

${ }^{\ddagger}$ Swiss National Bank, Börsenstrasse 15, P.O. Box, CH-8022 Zürich, Switzerland. E-mail: daniel.kaufmann@snb.ch

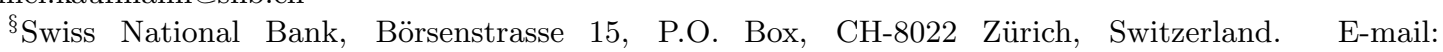
sarah.lein@snb.ch
} 


\section{Introduction}

A common pattern in micro data on consumer prices is that price increases are more frequent than price decreases. For example, in Switzerland $66.6 \%$ of all price changes are price increases. Similar asymmetries are documented for other countries (see, e.g., Álvarez et al., 2006; Klenow and Kryvtsov, 2008). One potential explanation for these asymmetries is downward nominal price rigidity. This implies that firms cannot reduce their nominal prices as often as they would like to and that some inflation may be beneficial because it "greases" the wheels of product markets by facilitating relative price cuts (see, e.g., Tobin, 1972; Akerlof et al., 1996).

However, the observation that prices increase more often than they fall is not sufficient to justify a positive inflation target. Another potential explanation of the observed asymmetry in price changes is trend inflation. Seminal contributions by Tsiddon (1993) and Ball and Mankiw (1994) show that asymmetries arise endogenously in a menu-cost model of price setting with trend inflation. This is because firms front load future inflation into the prices they currently set. It is thus an optimal choice to react less to negative shocks than to positive shocks of the same size, because inflation does part of the job of cutting relative prices without forcing firms to pay price adjustment costs. In these models, the asymmetry is endogenous and would disappear with zero trend inflation. A central bank should then optimally stabilize inflation at zero because inflation has a "sand" effect: positive inflation is inefficient because, with sticky prices, relative price variability lowers output and the distorted price signal does not allocate resources efficiently.

Thus, the policy implications depend on the source of the asymmetry. The extent to which aggregate inflation explains asymmetric price adjustments is not yet well established empirically. So far, most studies have focused on the response of output prices to changes in input prices (see Peltzman, 2000), on high-inflation environments (see Gagnon, 2009) or on downward rigidities in wages (see Fehr and Goette, 2005; ECB, 2009). One exception analyzing consumer prices is the working paper by Dhyne et al. (2007), who find that asymmetries in price-setting behavior are related to trends in marginal costs or desired markups.

In this paper we follow the recent empirical literature, that has specified reduced-form 
models for price setting that are closely tied to $(S, s)$-pricing rules, which relate the probability of observing a price adjustment to the deviation between the actual and the desired price. Our contribution to this literature is twofold. First, we propose an estimator that relaxes distributional assumptions on the price adjustment thresholds. We use a fixed effects approach, which does not make any assumptions on the relationship between the explanatory variables and the unobserved heterogeneity. Thus, the estimation of the parameters will not be contaminated by incorrect distributional assumptions concerning the unobserved heterogeneity. Second, our empirical application uses Swiss micro price data during a period of low inflation and examines how much of the asymmetry would be left over in a zero inflation environment.

Our results may be summarized as follows. A substantial share of asymmetries in the frequency of price changes can be traced back to a rising aggregate price level. Our counterfactual analysis shows that only a small share of the asymmetries would persist in the absence of aggregate inflation. According to our estimates, the share of price increases in all price changes would fall from $66.6 \%$ to $56.6 \%$ if aggregate inflation was zero. This finding is robust to different specifications of the model and covariates. It suggests that even in Switzerland, where aggregate inflation is on average below $1 \%$ over the sample period, already mild trend inflation implies that prices rise more frequently than they fall.

The remainder of this paper is structured as follows. Section 2 describes the model and Section 3 the data. Section 4 presents the results and Section 5 offers some conclusions.

\section{$2 \quad$ A model of asymmetric price adjustment}

In this paper we follow the recent empirical literature that has specified reduced-form models for price setting that are closely tied to $(S, s)$-pricing rules. The main idea of an $(S, s)$-policy is that the probability of observing an adjustment at the microeconomic level is an increasing function of the gap between the actual value of a variable and its desired target level (Caballero and Engel, 1993a). ${ }^{1}$ Such an adjustment behavior results

\footnotetext{
${ }^{1}$ Caballero and Engel (1993a) present a generalized $(S, s)$-adjustment policy and show the implications for aggregate dynamics using the example of employment adjustment. Caballero and Engel (1993b) show the aggregate implications of the adjustment policy for pricing decisions. Estimates of these rules based on microeconomic data can be found in Caballero et al. (1995) for investment decisions, in Caballero et al. (1997) for employment adjustment decisions, and in Eberly (1994) and Attanasio (2000) for households' durable purchases.
} 
from the assumption of non-convex adjustment costs. In the case of price setting, the estimated adjustment rule states that a price change occurs when the deviation between the desired price and the current one crosses an upper or lower adjustment threshold (see e.g. Fehr and Goette, 2005; Fougère et al., 2010; Dhyne et al., 2011a). ${ }^{2}$ These thresholds are motivated by assuming that firms have to pay menu costs for changing prices (see Sheshinski and Weiss, 1977) or that setting the desired price is prone to errors (see Costain and Nakov, 2011). Simple specifications of such a model can be thought of as generalizations of well-understood limited dependent variables models, such as the censored regression model. ${ }^{3}$

The empirical approach used here is to use insights from the literature concerned with estimation of limited dependent variables models to cast new light on the asymmetries in price adjustments. Since one of the primary focuses will be on unobserved heterogeneity, the literature concerned with estimation of panel data limited dependent variables models will be especially relevant. ${ }^{4}$

Let $p_{i t}^{*}$ denote the $\log$ of the unobserved desired price for a product $i$ at time $t$. We assume that this price can be modeled as a desired markup $\mu_{i}$ over nominal marginal cost $x_{i t}^{\prime} \beta$ and an idiosyncratic shock: ${ }^{5}$

$$
p_{i t}^{*}=\mu_{i}+x_{i t}^{\prime} \beta+\varepsilon_{i t}
$$

In the spirit of an $(S, s)$-pricing rule, there is an interval for the desired price change, $p_{i t}^{*}-p_{i, t-1}$, over which firms do not adjust prices. We denote this interval by $\left(\theta_{i t}^{-}, \theta_{i t}^{+}\right)$and model the thresholds as

$$
\begin{aligned}
& \theta_{i t}^{+}=z_{i t}^{\prime} \delta^{+}+u_{i}^{+} \\
& \theta_{i t}^{-}=z_{i t}^{\prime} \delta^{-}+u_{i}^{-},
\end{aligned}
$$

\footnotetext{
${ }^{2}$ See also Midrigan (2010) and Midrigan (2011) for calibration results of $(S, s)$-pricing rules.

${ }^{3}$ See, for example, Amemiya (1985) for a general discussion of limited dependent variables models, and Rosett (1959) for an early discussion of how transaction costs can lead to generalizations of the censored regression model.

${ }^{4}$ See, for example, Arellano and Honoré (2001) for an overview of that literature.

${ }^{5}$ We model the desired price - the price the firm sets once it pays the menu cost - rather than the optimal frictionless price. However, in structural models such as the one presented in Sheshinski and Weiss (1977), the desired price equals the optimal frictionless price plus a positive constant if trend inflation is positive (see Gautier and Le Bihan, 2011).
} 
where $z_{i t}$ denotes time-varying factors affecting the thresholds and $u_{i}^{+}$and $u_{i}^{-}$denote product-specific heterogeneity. Thus, the thresholds can vary over time and differ across products. It is implicit in (2)-(3) that $\theta_{i t}^{+} \geq \theta_{i t}^{-}$for all $t$ with probability 1 . This is a serious restriction on the possible values of $u_{i}^{+}$and $u_{i}^{-}$when the number of time periods for a product is large.

With this specification, the decision rule can be written as

$$
p_{i t}=\left\{\begin{array}{ccc}
p_{i t}^{*} & \text { if } & p_{i t}^{*}<p_{i t-1}+\theta_{i t}^{-} \\
p_{i t-1} & \text { if } & \text { otherwise } \\
p_{i t}^{*} & \text { if } & p_{i t}^{*}>p_{i t-1}+\theta_{i t}^{+}
\end{array}\right.
$$

In a cross-sectional model, this is the model proposed by Rosett (1959). ${ }^{6}$ In a panel data setting, it is closely related to a censored regression model with fixed effects of the form $p_{i t}=\max \left\{0, \mu_{i}+x_{i t}^{\prime} \beta+\varepsilon_{i t}\right\}$. Estimation of $\beta$ in this model was considered in Honoré (1992). The main challenge in (4) relative to the censored regression model is the presence of the fixed effect in the threshold as well as in the outcome equation. This makes a trivial extension of the ideas in Honoré (1992) impossible.

The model defined by (1)-(3) can be estimated by maximum likelihood if one is willing to make distributional assumptions on $\left(\left\{\varepsilon_{i t}\right\}, \mu_{i}, u_{i}^{+}, u_{i}^{-}\right)$. However, it is also possible to make progress without distributional assumptions. Specifically, let $y_{1 i t}$ be 1 if there is a price increase for product $i$ in time period $t$ and 0 otherwise. Then

$$
\begin{aligned}
y_{1 i t} & =1\left\{\triangle p_{i t}>0\right\}=1\left\{\mu_{i}+x_{i t}^{\prime} \beta+\varepsilon_{i t}>p_{i t-1}+z_{i t}^{\prime} \delta^{+}+u_{i}^{+}\right\} \\
& =1\left\{x_{i t}^{\prime} \beta-z_{i t}^{\prime} \delta^{+}-p_{i t-1}+\mu_{i}-u_{i}^{+}+\varepsilon_{i t}>0\right\}
\end{aligned}
$$

where $1\{A\}$ equals 1 if $A$ is true and 0 otherwise. Equation (5) has the structure of a discrete choice model with fixed effects. Manski (1987) shows how to consistently estimate the parameters $\beta$ and $\delta^{+}$of such a model with a fixed number of time periods for each $i{ }^{7}$ His approach allows $\mu_{i}-u_{i}^{+}$to be a "fixed effect" that can be arbitrarily correlated with the explanatory variables and the only real assumption is that $\left\{\varepsilon_{i t}\right\}_{t=1}$ is stationary

\footnotetext{
${ }^{6}$ See also Udry (1994).

${ }^{7}$ Formally, Manski (1987) showed how to estimate the parameters of such a model up to scale. Here, the scale is identified from the fact that the coefficient on $p_{i t-1}$ is -1 .
} 
conditional on the explanatory variables for each $i$. The weakness of this approach is that the resulting estimator is not asymptotically normal and converges to the true parameter values at a rate that is slower than the usual $\sqrt{n}$, where $n$ is the number of products. On the surface, this then seems like a poor estimator. However, Chamberlain (2010) showed that even with a parametric distributional assumption on $\varepsilon_{i t}$, it is essentially impossible to estimate the parameters of a fixed effect version of (5) at the usual $\sqrt{n}$ rate unless $\varepsilon_{i t}$ is i.i.d. logistic.

Inspired by Chamberlain's (2010) finding that root- $n$ consistent estimation of (5) is impossible unless $\varepsilon_{i t}$ is i.i.d. logistic, we proceed by specifying

$$
\begin{aligned}
y_{1 i t} & =1\left\{x_{i t}^{\prime} \beta-z_{i t}^{\prime} \delta^{+}-p_{i t-1}+\mu_{i}-u_{i}^{+}+\varepsilon_{i t}>0\right\} \\
& =1\left\{x_{i t}^{\prime} \beta / \kappa-z_{i t}^{\prime} \delta^{+} / \kappa-p_{i t-1} / \kappa+\left(\mu_{i}-u_{i}^{+}\right) / \kappa+\varepsilon_{i t} / \kappa>0\right\}
\end{aligned}
$$

where $\left\{\varepsilon_{i t} / \kappa\right\}$ is i.i.d. with a standard logistic distribution. With this assumption $\beta / \kappa, \delta^{+} / \kappa$ and $1 / \kappa$ can be estimated by the conditional maximum likelihood estimator introduced by Rasch (1960) and studied by Andersen (1970). Note that with this parameterization, $V\left[\varepsilon_{i}\right]=\frac{\pi^{2} \kappa^{2}}{3}$. For this reason, we also define $\sigma_{\varepsilon}=\frac{\pi \kappa}{\sqrt{3}}$.

Rather than focusing on price increases, we could also consider whether a price decreases in time period $t$. Let $y_{2 i t}$ be 1 if the price of product $i$ does not decrease in time period $t$ and 0 otherwise. Then

$$
\begin{aligned}
y_{2 i t} & =1\left\{\triangle p_{i t} \geq 0\right\}=\left\{\mu_{i}+x_{i t} \beta+\varepsilon_{i t} \geq p_{i t-1}+z_{i t}^{\prime} \delta^{-}+u_{i}^{-}\right\} \\
& =1\left\{x_{i t} \beta-z_{i t}^{\prime} \delta^{-}-p_{i t-1}+\mu_{i}-u_{i}^{-}+\varepsilon_{i t} \geq 0\right\} \\
& =1\left\{x_{i t} \beta / \kappa-z_{i t}^{\prime} \delta^{-} / \kappa-p_{i t-1} / \kappa+\left(\mu_{i}-u_{i}^{-}\right) / \kappa+\varepsilon_{i t} / \kappa \geq 0\right\}
\end{aligned}
$$

which can be estimated as above.

The conditional likelihood approach of Rasch (1960) and Andersen (1970) can be computationally burdensome if each product is observed over many time periods. It is therefore useful to proceed by using a slightly less efficient approach that uses all pairs of time periods $(t, s)$ for a given $i$ (rather than the whole series simultaneously). Writing (6) as $y_{i t}=1\left\{w_{i t}^{+} \gamma^{+}+\alpha_{i}^{+}+v_{i t}>0\right\}$ where $v_{i t}=\varepsilon_{i t} / \kappa$ is logistic, $w_{i t}^{+}=\left(x_{i t}, z_{i t}, p_{i t-1}\right)$, 
$\gamma^{+}=\left(\beta / \kappa, \delta^{+} / \kappa, 1 / \kappa\right)$ and $\alpha_{i}^{+}=\left(\mu_{i}-u_{i}^{+}\right) / \kappa$, we have

$$
P\left(y_{1 i t}=1 \mid w_{i t}^{+}, w_{i s}^{+}, \alpha_{i}\right)=\frac{\exp \left(w_{i t}^{+\prime} \gamma^{+}+\alpha_{i}^{+}\right)}{1+\exp \left(w_{i t}^{+\prime} \gamma^{+}+\alpha_{i}^{+}\right)}
$$

and

$$
\begin{aligned}
& P\left(y_{1 i t}=1, y_{1 i s}=0 \mid y_{1 i t}+y_{1 i s}=1, w_{i t}^{+}, w_{i s}^{+}, \alpha_{i}\right) \\
= & \frac{P\left(y_{1 i t}=1, y_{1 i s}=0 \mid w_{i t}^{+}, w_{i s}^{+}\right)}{P\left(y_{1 i t}=1, y_{1 i s}=0 \mid w_{i t}^{+}, w_{i s}^{+}\right)+P\left(y_{1 i t}=0, y_{1 i s}=1 \mid w_{i t}^{+}, w_{i s}^{+}\right)} \\
= & \frac{\frac{\exp \left(w_{i t}^{+\prime} \gamma^{+}+\alpha_{i}^{+}\right)}{1+\exp \left(w_{i t}^{+\prime} \gamma^{+}+\alpha_{i}^{+}\right)} \frac{1+\exp \left(w_{i s}^{+\prime} \gamma^{+}+\alpha_{i}^{+}\right)}{1+\exp \left(w_{i t}^{+\prime} \gamma^{+}+\alpha_{i}^{+}\right)} \frac{1}{1+\exp \left(w_{i s}^{+\prime} \gamma^{+}+\alpha_{i}^{+}\right)}+\frac{\exp \left(w_{i s}^{+} \gamma^{+}+\alpha_{i}^{+}\right)}{1+\exp \left(w_{i t}^{+\prime} \gamma^{+}+\alpha_{i}^{+}\right)} \frac{\exp \left(w_{i s}^{+\prime} \gamma^{+}+\alpha_{i}^{+}\right)}{\left.1+\alpha_{i}^{+}\right)}}{=} \\
& \frac{\exp \left(\left(w_{i t}^{+}-w_{i s}^{+}\right)^{\prime} \gamma^{+}\right)}{1+\exp \left(\left(w_{i t}^{+}-w_{i s}^{+}\right)^{\prime} \gamma^{+}\right)}
\end{aligned}
$$

Since the right-hand side does not depend on $\alpha_{i}$, this allows one to estimate $\gamma^{+}=$ $\left(\beta / \kappa, \delta^{+} / \kappa, 1 / \kappa\right)$ without assumptions on $\alpha_{i}$. In practice this is done by maximizing the pseudo log-likelihood for all pairs of observations for which $y_{1 i t}+y_{1 i s}=1$.

Likewise, $\left(\beta / \kappa, \delta^{-} / \kappa, 1 / \kappa\right)$ can be estimated by considering $y_{2 i t}$. We impose the constraint that $\beta / \kappa$ and $1 / \kappa$ should be the same when using $y_{1 i t}$ and when using $y_{2 i t}$ by maximizing the sum of the two pseudo log-likelihood functions. Specifically, we can estimate $\beta, \kappa, \delta^{+}$and $\delta^{-}$by maximizing the pseudo log-likelihod function

$$
\begin{array}{r}
\sum_{i=1}^{n} \sum_{1 \leq s \leq t \leq T_{i}} q_{i s t}^{1}\left(\beta, \delta^{+}, \delta^{-}, \kappa\right)+q_{i s t}^{2}\left(\beta, \delta^{+}, \delta^{-}, \kappa\right) \\
+q_{i s t}^{3}\left(\beta, \delta^{+}, \delta^{-}, \kappa\right)+q_{i s t}^{4}\left(\beta, \delta^{+}, \delta^{-}, \kappa\right)
\end{array}
$$


where

$$
\begin{aligned}
& q_{i s t}^{1}\left(\beta, \delta^{+}, \delta^{-}, \kappa\right)=1\left\{\triangle p_{i t} \geq 0, \triangle p_{i s}<0\right\} \\
& \log \left(\frac{\exp \left(\left(x_{i t}-x_{i s}\right)^{\prime} \beta / \kappa-\left(z_{i t}-z_{i s}\right)^{\prime} \delta^{-} / \kappa-\left(p_{i t-1}-p_{i s-1}\right) / \kappa\right)}{1+\exp \left(\left(x_{i t}-x_{i s}\right)^{\prime} \beta / \kappa-\left(z_{i t}-z_{i s}\right)^{\prime} \delta^{-} / \kappa-\left(p_{i t-1}-p_{i s-1}\right) / \kappa\right)}\right), \\
& q_{i s t}^{2}\left(\beta, \delta^{+}, \delta^{-}, \kappa\right)=1\left\{\triangle p_{i t}<0, \triangle p_{i s} \geq 0\right\} \\
& \log \left(\frac{1}{1+\exp \left(\left(x_{i t}-x_{i s}\right)^{\prime} \beta / \kappa-\left(z_{i t}-z_{i s}\right)^{\prime} \delta^{-} / \kappa-\left(p_{i t-1}-p_{i s-1}\right) / \kappa\right)}\right), \\
& q_{i s t}^{3}\left(\beta, \delta^{+}, \delta^{-}, \kappa\right)=1\left\{\triangle p_{i t}>0, \triangle p_{i s} \leq 0\right\} \\
& \log \left(\frac{\exp \left(\left(x_{i t}-x_{i s}\right)^{\prime} \beta / \kappa-\left(z_{i t}-z_{i s}\right)^{\prime} \delta^{+} / \kappa-\left(p_{i t-1}-p_{i s-1}\right) / \kappa\right)}{1+\exp \left(\left(x_{i t}-x_{i s}\right)^{\prime} \beta / \kappa-\left(z_{i t}-z_{i s}\right)^{\prime} \delta^{+} / \kappa-\left(p_{i t-1}-p_{i s-1}\right) / \kappa\right)}\right),
\end{aligned}
$$

and

$$
\begin{aligned}
q_{i s t}^{4}\left(\beta, \delta^{+}, \delta^{-}, \kappa\right) & =1\left\{\triangle p_{i t} \leq 0, \triangle p_{i s}>0\right\} \\
& \log \left(\frac{1}{1+\exp \left(\left(x_{i t}-x_{i s}\right)^{\prime} \beta / \kappa-\left(z_{i t}-z_{i s}\right)^{\prime} \delta^{+} / \kappa-\left(p_{i t-1}-p_{i s-1}\right) / \kappa\right)}\right)
\end{aligned} .
$$

Assuming random sampling across $i$, the asymptotic variance of this estimator can be derived and calculated using standard methods for extremum estimators. See, for example, Amemiya (1985).

This approach can be generalized in a number of ways. For example, Honoré and Powell (2005) use the same basic insight to estimate a partially linear logit model of the type

$$
P(y=1 \mid x, z)=\frac{\exp \left(x^{\prime} \beta+g(z)\right)}{1+\exp \left(x^{\prime} \beta+g(z)\right)}
$$

where $\beta$ is the parameter of interest, $g$ is an unknown and unspecified smooth function, and $z$ is a vector of possibly continuous explanatory variables. The approach in Honoré and Powell (2005) is to identify observations, $i$ and $j$, with similar values of $z$, and hence similar values of $g(z)$, and then treat $g(z)$ as a fixed effect for that pair. In 
practice this is done by using all pairs of observations and then weighting each pair by a kernel weight of the type $K\left(\frac{z_{i}-z_{j}}{h}\right)$ where $K$ is a kernel and $h$ is an appropriately chosen bandwidth, which in principle depends on the sample size. Inspired by this, we estimate $\beta, \kappa, \delta^{+}$and $\delta^{-}$by maximizing a modification of (7) that only uses pairs of time periods that differ by less than some number:

$$
\begin{array}{r}
\sum_{i=1}^{n} \sum_{\substack{1 \leq s \leq t \leq T_{i} \\
t-s \leq k}} q_{i s t}^{1}\left(\beta, \delta^{+}, \delta^{-}, \kappa\right)+q_{i s t}^{2}\left(\beta, \delta^{+}, \delta^{-}, \kappa\right) \\
+q_{i s t}^{3}\left(\beta, \delta^{+}, \delta^{-}, \kappa\right)+q_{i s t}^{4}\left(\beta, \delta^{+}, \delta^{-}, \kappa\right)
\end{array}
$$

If the model above is correctly specified then this estimator is still consistent and asymptotically normal, but it is likely to be less efficient than that defined by maximizing (7) ${ }^{8}$ However, the intuition is that the estimator defined by (8) is likely to be much more robust to a misspecification in which $\mu_{i}, u_{i}^{-}$and $u_{i}^{+}$change (slowly) over time.

\section{Data}

\subsection{Empirical specification}

We obtained micro price data underlying the Swiss CPI. ${ }^{9}$ The sampling decisions leave us with more than 3 million quarterly price quotes from Q1 1994 to Q4 2007 covering roughly $43 \%$ of the CPI basket at average expenditure weights (see Table 1). ${ }^{10}$

Table 1: Sample

\begin{tabular}{lrrrrr}
\hline & Weight & Sectors & Products & Individual products & Observations \\
\hline All sectors & 42.7 & 67 & 990 & 189,714 & $3,157,606$ \\
Non-durable & 22.1 & 38 & 560 & 116,969 & $2,132,911$ \\
Semi-durable & 4.5 & 11 & 181 & 32,528 & 469,635 \\
Durable & 7.9 & 10 & 179 & 32,366 & 379,605 \\
Services & 8.2 & 8 & 70 & 7,851 & 175,455 \\
\hline
\end{tabular}

The data set comprises price quotes of individual products; an individual product has

\footnotetext{
${ }^{8}$ Since both (7) and (8) are pseudo log-likelihood functions, it is not guaranteed that estimation based on (8) will lead to a less efficient estimator even though it uses stricly less information than (7)

${ }^{9}$ Source: Swiss Federal Statistical Office: data collection for the Swiss CPI 1993-2007.

${ }^{10} \mathrm{~A}$ detailed description of the data set is given in Kaufmann (2009). In what follows, we limit the discussion to the most relevant issues.
} 
a particular quality and quantity, and is on offer in a particular outlet. ${ }^{11}$ When individual products are out of stock, the statistical office collects prices for close substitutes. We call these close substitutes 'products.' The statistical office provides a variable that indicates whether the price quotes of close substitutes can be linked directly because they are of the same quality. If this is not the case, a new individual product starts.

The data set comprises less than $50 \%$ of the CPI basket because the statistical office uses other data sources to construct some of the price indices. The largest of these sectors are rents, telecommunication and books. Furthermore, some sectors drop out of the sample because they are not available over the whole sample period. We also only include products that were surveyed at least on a quarterly basis. ${ }^{12}$ Finally, we remove a few individual products with price changes larger than $200 \%$ and with missing data.

We restrict the analysis to permanent rather than temporary price changes because they are more important for aggregate predictions of menu-cost models (see Kehoe and Midrigan, 2007). A temporary price change is followed by the nominal price returning to its pre-period level. ${ }^{13}$ This definition identifies temporary price increases as well as decreases. In addition, the statistical office provides an indicator variable for sales. In periods with either temporary price changes or sales, we carry forward the pre-period price.

The micro price data give us the desired price conditional on observing a price change. For periods with no price changes, we model the desired price according to equation (1). We follow Cecchetti (1986) and use the accumulated sectoral inflation rate as a proxy for the change in nominal marginal costs. ${ }^{14}$ We match the inflation rates with the micro data at the three-digit COICOP level, which gives us 67 sectors. $^{15}$

\footnotetext{
${ }^{11} \mathrm{An}$ example is a $600 \mathrm{ml}$ family-size package of ice cream of a certain brand and flavor in a particular outlet.

${ }^{12}$ In our sample period, prices for some food items are available on a monthly basis. We use the last month of the quarter as the quarterly observation.

${ }^{13}$ For other ways of identifying temporary price changes, see Nakamura and Steinsson (2008) and Kehoe and Midrigan (2007).

${ }^{14}$ The sectoral inflation rate is not necessarily a good approximation to changes in nominal marginal costs for two reasons. First, desired prices may change because of aggregate inflation, real aggregate demand and productivity shocks (see, e.g., Nakamura and Steinsson, 2010). However, the sectoral inflation rate by itself does not allow us to disentangle the three. Fougère et al. (2010) use changes in minimum wages and producer price indices to model marginal costs for restaurants. However, we were not able to match our 67 sectors with corresponding producer price indices or wage indices. Second, the sectoral inflation rate is an average of changing prices and constant prices. An alternative would be to follow Bils et al. (2012) and calculate a measure of reset price inflation. This, however, we leave for future research.

${ }^{15}$ For a full list of these sectors, see Table 6 in the Appendix.
} 
We decompose the sectoral inflation rate into a sectoral inflation trend and sector-specific deviations from trend. On the one hand, this decomposition allows us to extract a persistent component of sectoral inflation that captures macroeconomic factors and sector-specific productivity trends. This accounts for the fact that price trends may be an important factor in explaining why price increases are more frequent than price decreases (see Tsiddon, 1993; Ball and Mankiw, 1994). On the other hand, the non-persistent component captures sector-specific productivity shocks that are unrelated to macroeconomic factors. We include these sector-specific shocks separately for positive and negative values because desired prices may react less to negative than to positive shocks of the same size if firms face an asymmetric profit function (see Ellingsen et al., 2006; Devereux and Siu, 2007). All variables are accumulated since the beginning of each individual product and therefore the empirical specification reads

$$
p_{i t}^{*}=\mu_{i}+\beta_{1} \Sigma \bar{\pi}_{j t}+\beta_{2} \Sigma \hat{\pi}_{j t}^{+}+\beta_{3} \Sigma \hat{\pi}_{j t}^{-}+\varepsilon_{i t},
$$

where $\bar{\pi}_{j t}$ denotes the sectoral inflation trend and $\hat{\pi}_{j t}^{+/-}$denote positive and negative sector-specific shocks.

To decompose the inflation rates, we follow Boivin et al. (2009) and use a principal components approach. ${ }^{16}$ We extract a vector of four factors $\left(\mathbf{C}_{t}\right)$ from a large macroeconomic data set including our sectoral inflation rates and estimate the corresponding factor loadings for each variable $\left(\lambda_{j}\right)$. Each sectoral inflation rate can be decomposed into an average $\left(\bar{\pi}_{j}\right)$, a common component $\left(\lambda_{j} \mathbf{C}_{t}\right)$ and an idiosyncratic component $\left(e_{j t}\right)$ :

$$
\pi_{j t}=\underbrace{\bar{\pi}_{j}+\lambda_{j} \mathbf{C}_{t}}_{\bar{\pi}_{j t}}+\underbrace{e_{j t}}_{\hat{\pi}_{j t}}
$$

The sectoral inflation trend for sector $j$ is then defined as the sum of the common component of the sectoral inflation rate and its mean. ${ }^{17}$ The sector-specific shocks are measured by the idiosyncratic component of the sectoral inflation rate. According to the

\footnotetext{
${ }^{16}$ The detailed approach and the macroeconomic data set are described in Kaufmann and Lein (2011).

${ }^{17}$ This differs from Dhyne et al. (2011a), who estimate a sector-specific price trend directly from micro price data.
} 
models in Tsiddon (1993) and Ball and Mankiw (1994), firms front load future inflation in the prices they currently set. Therefore, the persistent component is most likely the component on which firms front load. ${ }^{18}$

The price adjustment thresholds are modelled by including the non-accumulated rate of trend inflation $\left(\bar{\pi}_{j t}\right)$, seasonal time dummies and dummies for periods with VAT changes. This reflects the fact that menu costs may differ not only across individual products but also over time. Trend inflation is included in the threshold equation because the thresholds may vary with the level of inflation. This is because positive trend inflation makes it optimal to react more readily to positive shocks than to negative shocks of the same size, as future inflation erodes relative prices and thereby automatically leads to a relative price cut (see Ball and Mankiw, 1994). Thus, higher inflation reduces the upper threshold and raises the lower threshold (see also Gautier and Le Bihan, 2011). We include dummies for periods with VAT changes because such events give firms an opportunity to change prices as managerial and customer costs are particularly low (see Zbaracki et al., 2004; Fougère et al., 2010; Karadi and Reiff, 2010). Similarly, the seasonal dummies reflect the fact that menu costs may be low in certain months because of end-of-season sales or seasonal product replacements.

\subsection{Descriptive statistics}

The micro price data show that positive price changes are more frequent than negative price changes (see Table 2). ${ }^{19}$ On average, the relative frequency of price increases, that is, the share of price increases in all price changes, is $66.4 \% .{ }^{20}$ However, there are considerable differences across product types. For services, we find a relative frequency of price increases of $78.2 \%$. For non-durable goods, this frequency is lower, at $63.3 \%$. Price increases are even more frequent if we focus on small price changes. The average relative frequency of small price increases exceeds $70 \%$. This is consistent with the findings in Chen et al. (2008).

\footnotetext{
${ }^{18}$ In the spirit of Boivin et al. (2009), Kaufmann and Lein (2011) show that the sector-specific component is not persistent, while the common component is highly persistent.

${ }^{19}$ These statistics broadly repeat the findings in Kaufmann (2009). Some differences emerge because of different sampling decisions. In particular, the $\% \mathrm{fpc}^{+}$is higher than in the earlier study (1993-2000: $56.2 \% ; 2000-2005$ : $58.7 \%$ ).

${ }^{20}$ The descriptive statistics for all sectors can be found in Table 6 in the Appendix.
} 
Table 2: Frequency of positive and negative price changes

\begin{tabular}{lrrrrrrr}
\hline & \multicolumn{3}{c}{ All price changes } & & \multicolumn{3}{c}{ Small price changes } \\
\cline { 2 - 3 } \cline { 7 - 8 } & $\mathrm{fpc}^{+}$ & $\mathrm{fpc}^{-}$ & \%fpc $^{+}$ & & $\mathrm{fpc}^{+}$ & $\mathrm{fpc}^{-}$ & \%fpc $^{+}$ \\
\hline All sectors & 8.8 & 4.6 & 66.4 & & 3.3 & 1.3 & 71.5 \\
Non-durable & 9.2 & 5.3 & 63.3 & & 3.1 & 1.6 & 66.0 \\
Semi-durable & 6.4 & 3.6 & 64.2 & & 2.6 & 1.1 & 71.4 \\
Durable & 9.7 & 5.4 & 64.2 & & 4.1 & 1.4 & 74.5 \\
Services & 8.0 & 2.2 & 78.2 & & 3.2 & 0.6 & 83.2 \\
\hline
\end{tabular}

Note: The table gives statistics on the frequency of price changes. $\mathrm{fpc}^{+}, \mathrm{fpc}^{-}$: positive, negative frequency of price changes; $\% \mathrm{fpc}^{+}$: relative $\mathrm{fpc}^{+}=100 \times \mathrm{fpc}^{+} /\left(\mathrm{fpc}^{+}+\mathrm{fpc}^{-}\right)$. Following Midrigan (2011) a 'small' price change is smaller than half of the average absolute price change in the corresponding sector. The statistics are calculated for 67 sectors and then aggregated using average expenditure weights.

Figure 1 shows in a scatter plot the relationship between the relative frequency of price changes and the mean inflation rate for each sector. We find a significantly positive relationship (Panel a). The $R^{2}$ suggests that the sectoral inflation rate explains more than $40 \%$ of the cross-sectional variation in the $\% \mathrm{fpc}^{+}$. The relationship is weaker for small price changes. This is at odds with the prediction of the Ball and Mankiw (1994) model. Theory predicts that positive trend inflation mainly leads to more small price increases relative to small price decreases because trend inflation is most relevant in sectors with small idiosyncratic shocks and large menu costs (see, e.g., Gagnon, 2009). Therefore, positive trend inflation may not be the only reason why price increases are more frequent than decreases. ${ }^{21}$

The scatter plot is a simple way to gauge the relative frequency of positive price changes for a sector with zero mean inflation. According to the intercept of the regression line, a sector with zero inflation displays a relative frequency of positive price changes of $64.6 \%$. For small price changes, the intercept is higher, which emphasizes that small price increases would be frequently observed even in the absence of sectoral price trends. Using this cross-sectional regression to explain the prevalence of positive price changes has a major disadvantage. If we set the sectoral inflation rate to zero, we assume that both, the aggregate inflation rate and sectoral productivity growth are zero. However, the scatter plot shows that there is a large heterogeneity in the mean of the sectoral inflation rates,

\footnotetext{
${ }^{21}$ The weak relationship may also stem from sampling error and quality adjustments. Eichenbaum et al. (2012) show for US micro data that the prevalence of small price changes is largely due to sampling error and quality adjustment. They argue that the importance of small price changes for evaluating macroeconomic models is therefore overrated.
} 
Figure 1: Relative frequency and sectoral trend inflation

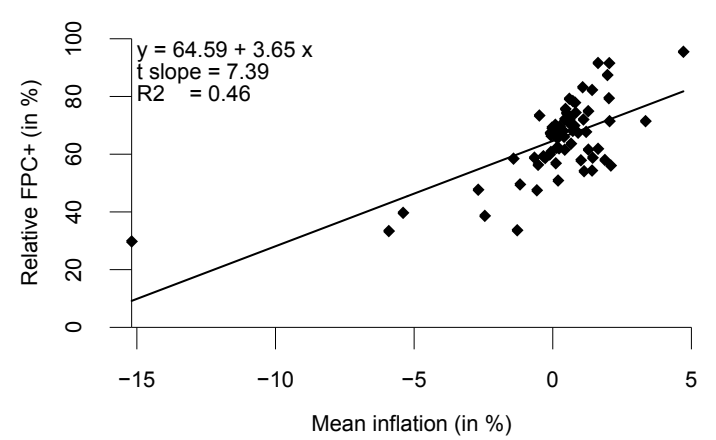

(a) All price changes

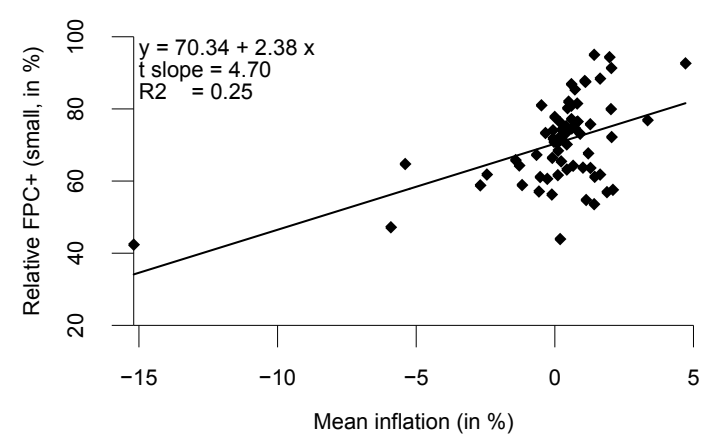

(b) Small price changes

Note: The figures give scatter plots and regressions of the relationship between the relative frequency of price changes and the sectoral trend inflation rate. Panel (a) shows the results for all price changes, panel (b) for small price changes. Following Midrigan (2011) a 'small' price change is smaller than half of the average absolute price change in the corresponding sector.

which points to different productivity trends. For policy purposes, we have to disentangle the effect of aggregate inflation from these relative price trends. We are interested in the question: would asymmetry disappear in an environment with zero aggregate inflation? Therefore, we use our model estimates and make counterfactual predictions.

\section{Results}

This section examines to what extent the relative frequency of positive price changes can be explained by trend inflation. We first discuss the estimation results and which covariates are most important to explain the frequency of positive and negative price changes. We then perform a counterfactual analysis showing by how much the relative frequency of positive price changes would fall if aggregate inflation was zero. Finally, we offer some robustness checks.

\subsection{Estimation results}

We estimate the coefficients of the desired price equation controlling for heterogeneity at the level of individual products. As discussed in Section 2, it is potentially desirable to use only pairs of time periods that are fairly close. We therefore use pairs that differ by no more than 12 quarters. This makes the results more robust to the assumption 
that the fixed effects in the thresholds and in the pricing equation are constant over the whole sample period. An alternative way would be to introduce a stochastic term in the adjustment thresholds, as, for example, in Gautier and Le Bihan (2011). They emphasize that this is necessary to allow for time-varying stochastic price adjustment thresholds because otherwise $(S, s)$-pricing rules have difficulty in matching the prevalence of small price changes. ${ }^{22}$ In particular, the price adjustment thresholds tend to be too wide and the variance of the idiosyncratic shocks tends to be too large (see Dhyne et al., 2011b).

Table 3 reports the estimation results for our 67 sectoral models. The first panel summarizes the estimates of the desired price equation. For each model and for each coefficient, we perform a one-sided test with the alternative hypothesis that the coefficient is larger than zero. The table reports the weighted average of the coefficients across all sectors conditional on this alternative hypothesis. ${ }^{23}$ As a measure of significance, we report the share of sectors for which we reject the null hypothesis at the $5 \%$ level in brackets. All statistics are weighted by the corresponding average CPI expenditure weights. The second panel tests whether the reaction to positive sector-specific shocks is significantly different from the reaction to negative sector-specific shocks. The third panel gives averages of the estimated variance and of the price adjustment thresholds.

In almost all sectors, relative price trends have a significantly positive impact on desired prices. At the $5 \%$ level, the share of sectors with a positive coefficient amounts to $94 \%$. On average, a $1 \%$ increase in the sectoral price trend raises the firm's desired price by $1.16 \%$. This suggests that, in the long run, desired prices move one-for-one with the sectoral price trend. This finding is common across product types. For three out of four product types, the share of sectors that significantly react to the sectoral price trend is larger than $90 \%$ and the average coefficient is close to 1 (non-durable goods, durable goods and services). For semi-durable goods, the share of significant coefficients amounts to only $63 \%$, because, for some semi-durable goods, the coefficient is not significantly different from zero or even negative. ${ }^{24}$

\footnotetext{
${ }^{22}$ See Dotsey et al. (1999) and Midrigan (2011) for theoretical frameworks and Fougère et al. (2010) and Dhyne et al. (2011a) for empirical applications.

${ }^{23}$ Detailed estimates for each model can be found in the Appendix in Tables $8-14$.

${ }^{24}$ See Table 7 in the Appendix for more tests of hypotheses. One problem for semi-durable goods may be that the sectoral inflation rates are not very good proxies. We use an alternative proxy as a robustness check in the last section of this chapter.
} 
Table 3: Estimates of desired price equation

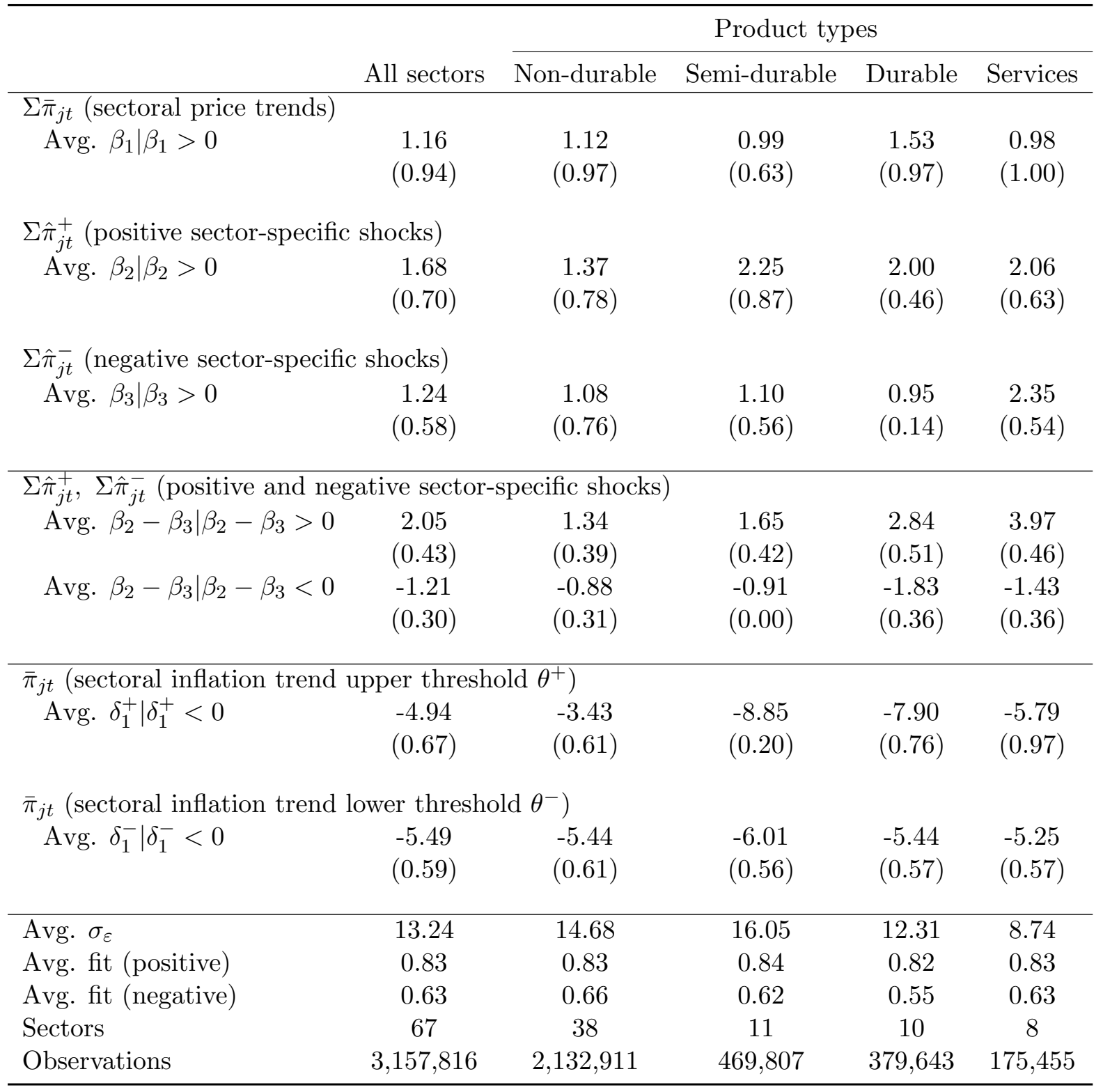

Note: The table summarizes the estimation results for 67 sectoral models. The first panel gives the estimates for the desired price equation $\left(p_{i t}^{*}=\mu_{i}+\beta_{1} \Sigma \bar{\pi}_{j t}+\beta_{2} \Sigma \hat{\pi}_{j t}^{+}+\beta_{3} \Sigma \hat{\pi}_{j t}^{-}+\varepsilon_{i t}\right)$. All explanatory variables are measured in logarithms multiplied by 100. For each model, we perform tests for which the alternative hypothesis is given in the first column. We then report averages of the coefficients, weighted by the sectoral expenditure weight, conditional on this alternative hypothesis. We report in brackets the share of sectors where we reject the null hypothesis at the $5 \%$ level. The second panel tests whether the reaction to positive sector-specific shocks is significantly different from the reaction to negative sector-specific shocks. The third panel shows the estimates of the average coefficient on the sectoral inflation trend in the threshold equation $\left(\theta_{i t}^{+/-}=\delta_{1}^{+/-} \bar{\pi}_{j t}+\ldots\right)$. The fourth panel gives averages of the estimated variance of idiosyncratic shocks and some summary statistics. The measure of fit uses pairs of time periods for a given product where there is a price change in one period but not in the other. The measure of fit for positive changes is defined as the fraction of pairs for which the model predicts a higher probability of a price increase in the period with the price increase. The measure of fit for negative price changes is defined accordingly. 
The coefficients are also mostly significant for positive and for negative sector-specific shocks. In $70 \%$ of the sectors, firms' desired prices react significantly to positive sector-specific shocks. The share of sectors with a significant reaction to negative shocks is somewhat smaller $(58 \%)$. In addition, the average coefficient on positive sector-specific shocks (1.68) is larger than the average coefficient on negative sector-specific shocks (1.24). This is a common pattern across all product types and suggests that desired prices usually react more to positive than to negative shocks. ${ }^{25}$ We therefore test whether the reaction coefficients are significantly different from each other.

The second panel shows that the share of sectors for which we find a stronger reaction to positive than to negative shocks $(43 \%)$ is somewhat higher than the share of sectors for which we find the opposite (30\%). Even though the average coefficient on positive shocks is larger, we cannot conclude that there is broad-based evidence that desired prices react more strongly to positive than to negative sector-specific shocks. Indeed, there are differences across product types. For non-durable goods and services, the share of sectors that respond more to positive shocks is only slightly higher than the share of sectors that respond more to negative shocks. Differences are more pronounced for semi-durable and durable goods.

The thresholds vary with the level of inflation. Theoretical predictions suggest that both the upper and the lower threshold shift downwards with a higher level of inflation, making the range of inaction smaller for price increases and larger for price decreases. This prediction is largely supported by our results reported in the third panel. In almost $70 \%$ of all sectors, sectoral trend inflation has a significantly negative impact on the level of the upper thresholds. Likewise, in about $60 \%$ of the sectors, inflation shifts the lower threshold downwards. The effect of inflation on the upper threshold is almost always significantly negative for services, but in $20 \%$ of the semi-durable goods sectors. Meanwhile, the effect on the lower threshold is relatively homogeneous across sectors.

\footnotetext{
${ }^{25}$ The only exception is services, where we find a slightly higher average coefficient for negative shocks than for positive shocks.
} 


\subsection{The relative importance of price trends and sector-specific shocks}

In our empirical specification, desired prices may rise more often than they fall because of sectoral price trends or because of asymmetric reactions to positive and negative shocks. We now ask which of the three components is most important for explaining the cross-sectional variation in the relative frequency of positive price changes. We calculate for each observation the probability of a price increase and decrease at actual sample values. The simulated relative frequency of positive price changes $\left(\% \widetilde{\mathrm{fpc}}^{+}\right)$is then given by the average probability of a price increase divided by the average probability of a price change.

To simulate the relative frequency of price increases, we have to obtain a value of the fixed effects. In fact, we only need to know $\left(\mu_{i}-u_{i}^{+}\right)$and $\left(\mu_{i}-u_{i}^{-}\right)$instead of all three fixed effects separately. ${ }^{26}$ We calibrate the two differences to match the frequency of positive and negative price changes. This boils down to re-estimating the model by maximum likelihood and restricting all coefficients to the values from the fixed effects estimator. Calibrating a different fixed effect for each individual product is problematic because for some individual products we observe only price increases or price decreases. We therefore calibrate the fixed effects for the aggregation level of products rather than for individual products. ${ }^{27}$

In the first column of Table 4 we regress the $\% \mathrm{fpc}^{+}$on the model predictions at actual sample values. The $R^{2}$ equals almost 1 by construction because we calibrated the fixed effects to match the positive and negative frequency of price changes. In the remaining columns we set one of the covariates to zero to simulate the relative frequency of positive price changes. The size of the drop in the $R^{2}$ gives us an idea of to what extent the corresponding covariate helps to explain the cross-sectional variation of the relative frequency of positive price changes.

Sectoral price trends explain a large share of the cross-sectional variation in the $\% \mathrm{fpc}^{+}$. If we set the sectoral price trend to zero, the remaining variables in the model explain only $48 \%$ of the cross-sectional variation $\left(\Sigma \bar{\pi}_{j t}=0\right)$. If we set the positive and negative

\footnotetext{
${ }^{26}$ Unfortunately, we cannot simulate the size of price changes without knowing $\mu_{i}$.

${ }^{27}$ The advantage of this procedure is that our estimates of the desired price equation are not contaminated by any distributional assumptions about the fixed effects.
} 
Table 4: Explanatory power of $\% \mathrm{fpc}^{+}$

\begin{tabular}{lrrrr}
\hline & Model & $\Sigma \bar{\pi}_{j t}=0$ & $\Sigma \hat{\pi}_{j t}^{+}=0$ & $\Sigma \hat{\pi}_{j t}^{-}=0$ \\
\hline Constant & -1.01 & 8.81 & 11.86 & 8.29 \\
Slope & 1.02 & 0.91 & 0.83 & 0.86 \\
$R^{2}$ & 0.99 & 0.48 & 0.96 & 0.94 \\
Sectors & 67 & 67 & 67 & 67 \\
\hline
\end{tabular}

Note: The table shows coefficients and the $R^{2}$ from a regression of the actual relative frequency of positive price changes $\left(\% \mathrm{fpc}^{+}\right)$on the simulated $\% \mathrm{fpc}^{+}\left(\% \widetilde{\mathrm{fpc}}^{+}\right)$and a constant. The first column shows the results at actual sample values. In the subsequent columns we repeat the regression with a simulated $\% \mathrm{fpc}^{+}$where the corresponding covariate shown in the first row is set to zero.

sector-specific shocks to zero, the $R^{2}$ falls only slightly, to $96 \%$ and $94 \%$, respectively $\left(\Sigma \hat{\pi}_{j t}^{+}=0\right.$ and $\left.\Sigma \hat{\pi}_{j t}^{-}=0\right)$. This suggests that the sectoral price trend is more important for fitting the cross-sectional variation in the relative frequency of positive price changes than is the asymmetric reaction to positive and negative sector-specific shocks.

\subsection{Asymmetries in the absence of aggregate inflation}

The descriptive statistics and the model estimates suggest that sectoral price trends explain a considerable share of the relative frequency of positive price changes. We now use our estimated price-setting rules to show whether the relative frequency of positive price changes is mainly driven by positive aggregate inflation. In particular, we make counterfactual predictions, which tell us by how much the asymmetry would be reduced if aggregate inflation was zero. We emphasize this counterfactual, because aggregate inflation can be influenced by monetary policy and thus bears important policy implications. In addition, we examine the counterfactual of zero sectoral inflation for all sectors.

Table 5 gives model predictions for various paths of the desired price. The first two columns give the actual $\% \mathrm{fpc}^{+}$and the model predictions at actual sample values, respectively. The third and fourth columns assume that aggregate inflation is zero. We show the counterfactuals in two steps because trend inflation has two effects on asymmetry. First, desired prices rise on average with positive aggregate inflation. We examine this first effect in the third column by subtracting the accumulated aggregate inflation rate from the sectoral inflation trend $\left(\beta_{1}\left[\Sigma \bar{\pi}_{j t}-\Sigma \pi_{t}\right]\right)$ in the desired price equation, but we leave the threshold equation unchanged. ${ }^{28}$ Second, the price adjustment thresholds become

\footnotetext{
${ }^{28}$ We assume that firms' desired price is a markup over nominal marginal costs. By subtracting accumulated aggregate inflation from the sectoral price trend we therefore evaluate the prediction of the model if firms' real marginal costs are equal to their nominal marginal costs.
} 
asymmetric with positive trend inflation because higher trend inflation continuously reduces relative prices if prices remain unchanged. Thus, the upper thresholds become smaller and the lower thresholds larger in absolute terms. We examine this second effect in the fourth column by subtracting the accumulated aggregate inflation rate from the sectoral inflation trend in the desired price equation and subtracting the level of aggregate inflation from the level of sectoral inflation in the threshold equation $\left(\delta_{1}\left[\bar{\pi}_{j t}-\pi_{t}\right]\right)$. The last two columns predict the relative frequency assuming that all sectoral inflation rates are zero. The two counterfactuals are analogous to the ones described above.

Table 5: Counterfactual predictions $\% \mathrm{fpc}^{+}$

\begin{tabular}{lrrrrrr}
\hline & Data & Model & $\pi_{t}=0^{(1)}$ & $\pi_{t}=0^{(2)}$ & $\pi_{j t}=0^{(1)}$ & $\pi_{j t}=0^{(2)}$ \\
\hline All sectors & 66.4 & 66.1 & 61.0 & 56.6 & 62.6 & 60.3 \\
Non-durable & 63.3 & 63.0 & 57.3 & 53.1 & 60.3 & 56.1 \\
Semi-durable & 64.2 & 63.5 & 61.9 & 59.2 & 63.0 & 64.1 \\
Durable & 64.2 & 64.2 & 58.4 & 49.7 & 62.9 & 64.0 \\
Services & 78.2 & 77.7 & 73.1 & 71.2 & 68.1 & 65.8 \\
\hline
\end{tabular}

Note: The table gives model predictions for various paths of the desired price. The first two columns give the actual $\% \mathrm{fpc}^{+}$and the model predictions at actual sample values, respectively. The third and fourth columns assume that aggregate inflation is zero by subtracting aggregate inflation from the sectoral inflation trend $\left(\beta_{1}\left[\Sigma \bar{\pi}_{j t}-\Sigma \pi_{t}\right]\right)$. (1) assumes that the thresholds remain fixed with zero inflation. (2) takes into account that the thresholds vary endogenously with changes in inflation by additionally setting inflation to zero in the threshold equation $\left(\delta_{1}\left[\bar{\pi}_{j t}-\pi_{t}\right]\right)$. Columns five and six replicate the previous two counterfactuals but assume that the sectoral inflation rate is zero, i.e., $\bar{\pi}_{j t}+\hat{\pi}_{j t}^{+}+\hat{\pi}_{j t}^{-}=0$ for all $j, t$.

The relative frequency of price increases would drop significantly with zero aggregate inflation. But we would still observe more price increases than decreases. The third column shows the results with zero aggregate inflation if we assume that the thresholds remain unchanged, that is, we set aggregate inflation to zero in the desired price equation but not in the threshold equation $\left(\pi_{t}=0^{(1)}\right)$. On average, over all sectors, we find that the $\% \mathrm{fpc}^{+}$drops by almost $5.5 \mathrm{pp}$, to $61.0 \%$, if we set aggregate inflation to zero. Thus, the fact that desired prices rise on average with positive trend inflation already explains a substantial part of the observed asymmetries. The effect is somewhat smaller for semi-durable goods and about equally large for non-durable goods, durable goods and services.

It is important to take into account that the thresholds also vary with inflation. In the fourth column, we set aggregate inflation to zero in the threshold equation. ${ }^{29}$ The

\footnotetext{
${ }^{29}$ The threshold equation contains the sectoral inflation trend. Thus, we subtract the aggregate inflation rate from the sectoral inflation rate for both the desired price equation and the threshold equation.
} 
asymmetry reduces by another $4.4 \mathrm{pp}$ to $56.6 \%$. Thus, in the absence of aggregate inflation, the asymmetries would be significantly reduced. This result also shows that the endogeneity in the estimated thresholds is non-negligible.

The counterfactuals derived from our estimated models differ from the predictions of the scatter plot in Figure 1. The fifth column in Table 5 shows why. If we set all sectoral inflation rates to zero for calculating the desired price, we assume not only that aggregate inflation is zero but also that productivity remains constant in all sectors, or in other words, the desired price remains on average unchanged. Price changes are then triggered exclusively by idiosyncratic shocks that are on average zero and have an estimated variance $\sigma_{\varepsilon}$. Consistent with the scatter plot, our models predict the relative frequency of positive price changes at $62.6 \%$ if sectoral inflation is set to zero. Taking the endogeneity of the thresholds into account would reduce the asymmetry to $60.3 \%$, again suggesting that the endogeneity of the threshold matters. This, however, can also not be captured by the simple intercept prediction in Figure 1.

Even though asymmetries are substantially reduced in a zero inflation environment, we still find somewhat more price increases than decreases. This remaining asymmetry may reflect deep downward rigidity, which may be a result of asymmetric price adjustment thresholds. A theoretical explanation for asymmetric adjustment thresholds can also be found in Golosov and Lucas (2007). They show that the region of inaction is cone-shaped as a function of productivity. For low levels of productivity, the band of inaction is wider than it is for high levels of productivity because high-productivity firms have low prices and sell high quantities, while the opposite is the case for low-productivity firms. Klenow and Kryvtsov (2008) show that the $(S, s)$-band becomes increasingly asymmetric with higher elasticity of demand, which implies that the profit function is more asymmetric. Thus, price decreases become less frequent and larger in absolute terms than price increases, a result that is not related to the level inflation. ${ }^{30}$

The result that asymmetries can, to a large extent, be related to trend inflation is also in line with evidence from Japan. During the period when inflation was low or even negative, workers started to accept nominal wage cuts (see Kuroda and Yamamoto, 2003). This may

\footnotetext{
${ }^{30}$ This would imply that sectors with high productivity should have a relatively narrow range of inaction, while sectors with low productivity have a wide range of inaction. Exploring this further is beyond the scope of the paper.
} 
be because they did not expect any inflation or productivity growth in the medium term. Also, consumer price decreases were common during this period, and asymmetry in the frequency of price increases and decreases disappeared. Higo and Saita (2007) show that during this period, the frequency of price increases is almost equivalent to that of price decreases. ${ }^{31}$

\subsection{Robustness tests}

To examine the robustness of our results, we estimated four alternative specifications. ${ }^{32}$ First, we estimated the models using all price changes, not only those within a range of 12 quarters. Second, we added aggregate variables to our empirical specification of the desired price. Third, we used an alternative measure of the sectoral price trend. Finally, we approximated the desired price change by the average price change observed in our data set instead of the sectoral inflation rate.

Our main specification compared only price changes within a range of 12 quarters. Now, we assume that the fixed effects remain constant over a period of 14 years. ${ }^{33}$ The estimated standard deviation of the idiosyncratic shock gets unrealistically large. Moreover, the average price adjustment thresholds increase in absolute size. This is an undesirable feature of the more restrictive model because it implies that the size of price changes would on average increase. Therefore, we are unlikely to fit the prevalence of small price changes observed in the data. ${ }^{34}$ Nevertheless, the counterfactual predictions with respect to the relative frequency of positive price changes are not qualitatively affected by using the more restrictive model. ${ }^{35}$ Intuitively, the variance of idiosyncratic shocks scales all parameters by the same amount so that the probability of observing a price increase or decrease is not greatly affected even though the size of price adjustments may well be (see

\footnotetext{
${ }^{31}$ The result is also not inconsistent with findings in the literature that aggregate inflation explains only a tiny fraction of the variation in nonzero nominal price changes (see Eden, 2001). This is because idiosyncratic factors are most important in explaining individual price changes (see Lein, 2010). Nevertheless, the small fraction of the variation that aggregate factors explain may still be important in the aggregate because these aggregate shocks affect all firms, especially those that are just at the margin of adjustment.

${ }^{32}$ All results of the robustness tests are available in the Appendix.

${ }^{33}$ See Table 15 in the Appendix

${ }^{34}$ Dhyne et al. (2011a) note that: "[using binary response models] neglects the information contained in the magnitude of price changes. However, this information is crucial for identifying the volatility of the idiosyncratic component and for disentangling the idiosyncratic component of the optimal price from the idiosyncratic threshold variable."

${ }^{35}$ See Table 19 in the Appendix.
} 
Equation 6).

As a second robustness check, we added accumulated aggregate inflation as well as aggregate accumulated personal consumption expenditures to our empirical specification. Even though the effect of aggregate inflation on the desired price is significantly larger than zero in only about one-fourth of the sectors, sectoral trend inflation remains significant in almost $70 \%$ of all sectors. ${ }^{36}$ This suggests that aggregate inflation is already captured in the sectoral inflation trends. Indeed, the counterfactual predictions of this specification imply that the relative frequency of positive price changes falls to $57.7 \%$ at zero aggregate inflation, taking into account the endogenous thresholds. ${ }^{37}$

As a third robustness check, we repeated the analysis using a Hodrick-Prescott filter to obtain an alternative estimate of the price trend. With this alternative decomposition, deviations from this trend are not necessarily sector-specific. Most of the results prove robust to this alternative. ${ }^{38}$ The effect of aggregate inflation on the $\% \mathrm{fpc}^{+}$in the counterfactual analysis is even larger than in our baseline specification. ${ }^{39}$ This, however, is driven mainly by durable goods, where the counterfactual frequency drops substantially when subtracting aggregate inflation from the thresholds.

One puzzling result of our main specification is that some coefficients on the sectoral price trends, especially for semi-durable goods, are negative. This would imply that desired prices decline if the average sectoral price increases. In particular, this affected our results for semi-durable goods. Our main specification uses the sectoral inflation rates published by the statistical office. Because of our sampling decisions described above, these official inflation rates do not have to fully correspond to our micro data set. Prices may be included in the calculation of the sectoral inflation rate that are not in our micro data set. We therefore use the average price change observed in each sector as a proxy for changes in nominal marginal costs instead of the sectoral inflation rate. As a consequence, the share of sectors where we find a negative sign in the desired price equation is zero. ${ }^{40}$ This affects our counterfactual predictions only marginally. If we set aggregate inflation to zero and take the endogeneity of the price adjustment thresholds into account we find a $\% \mathrm{fpc}^{+} \mathrm{at}^{-}$

\footnotetext{
${ }^{36}$ See Table 16 in the Appendix.

${ }^{37}$ See Table 20 in the Appendix.

${ }^{38}$ See Table 17 in the Appendix.

${ }^{39}$ See Table 21 in the Appendix.

${ }^{40}$ See Table 18 in the Appendix.
} 


\section{Conclusions}

Prices increase but they do not fall. This is a popular preconception with a germ of truth. Price data underlying the Swiss CPI tell the same story as price data for many other countries; price increases are usually more frequent than price decreases. In this paper, we relate this finding to economic theory.

One explanation may be that there is a deep downward price rigidity and that firms cannot reduce prices, even if they would like to. However, our results support a second explanation. Trend inflation is the key factor explaining asymmetries observed in the data, even in a low inflation environment. Our findings support the view that the asymmetry is endogenous; counterfactual analysis shows that if aggregate inflation was be zero, the asymmetries would be reduced substantially.

The policy implications of our empirical results follow from Ball and Mankiw (1994) at least to the extent that the asymmetries are explained by trend inflation. Most of the asymmetries would disappear if inflation was stabilized at zero. Such a stabilization policy is optimal for product markets because positive inflation increases relative price variability and lowers output, as the distorted price signal does not allocate resources efficiently. This stands in contrast to the argument put forward by Tobin (1972) and Akerlof et al. (1996), for example, that a central bank should adopt a positive inflation target if prices are downwardly rigid in nominal terms.

Nevertheless, the scope of these policy implications is limited. A positive inflation target may still be optimal. First, even though consumer prices may not be downwardly rigid in the absence of inflation, wages may well be. Thus, inflation may have a sand effect in the product market but a grease effect in the labor market. Second, a positive inflation target may take into account quality improvements, which are not captured in the calculation of the aggregate inflation rate.

\footnotetext{
${ }^{41}$ See Table 22 in the Appendix.
} 


\section{References}

Akerlof, G. A., W. R. Dickens, And G. L. Perry (1996): "The Macroeconomics of Low Inflation," Brookings Papers on Economic Activity, 27, 1-76.

Álvarez, L. J., E. Dhyne, M. Hoeberichts, C. Kwapil, H. L. Bihan, P. Lnnemann, F. Martins, R. Sabbatini, H. Stahl, P. Vermeulen, And J. Vilmunen (2006): "Sticky Prices in the Euro Area: A Summary of New Micro-Evidence," Journal of the European Economic Association, 4, 575-584.

AmemiYa, T. (1985): Advanced Econometrics, Harvard University Press.

Andersen, E. B. (1970): "Asymptotic Properties of Conditional Maximum-Likelihood Estimators," Journal of the Royal Statistical Society. Series B (Methodological), 32, 283-301.

Arellano, M. And B. E. Honoré (2001): "Panel Data Models: Some Recent Developments," in Handbook of Econometrics, ed. by J. Heckman and E. Leamer, Elsevier, vol. 5, chap. 53, 3229-3296.

Attanasio, O. P. (2000): "Consumer Durables and Inertial Behavior: Estimation and Aggregation of (S,s) Rules for Automobile Purchases," Review of Economic Studies, 67, $667-696$.

Ball, L. and N. G. Mankiw (1994): "Asymmetric Price Adjustment and Economic Fluctuations," Economic Journal, 104, 247-61.

Bils, M., P. J. Klenow, And B. A. Malin (2012): "Reset Price Inflation and the Impact of Monetary Policy Shocks," American Economic Review, forthcoming.

Boivin, J., M. P. Giannoni, And I. Mihov (2009): "Sticky Prices and Monetary Policy: Evidence from Disaggregated US Data," American Economic Review, 99, 350-84.

Caballero, R. J. and E. M. R. A. Engel (1993a): "Microeconomic Adjustment Hazards and Aggregate Dynamics," Quarterly Journal of Economics, 108, 359-83. (1993b): "Microeconomic Rigidities and Aggregate Price Dynamics," European Economic Review, 37, 697-711. 
Caballero, R. J., E. M. R. A. Engel, and J. Haltiwanger (1997): "Aggregate Employment Dynamics: Building from Microeconomic Evidence," American Economic Review, 87, 115-37.

Caballero, R. J., E. M. R. A. Engel, and J. C. Haltiwanger (1995): "Plant-Level Adjustment and Aggregate Investment Dynamics," Brookings Papers on Economic Activity, 26, 1-54.

Cecchetti, S. G. (1986): "The Frequency of Price Adjustment: A Study of the Newsstand Prices of Magazines," Journal of Econometrics, 31, 255-274.

Chamberlain, G. (2010): "Binary Response Models for Panel Data: Identification and Information," Econometrica, 78, 159-168.

Chen, H. A., D. Levy, S. Ray, and M. Bergen (2008): "Asymmetric Price Adjustment in the Small," Journal of Monetary Economics, 55, 728-737.

Costain, J. And A. NAkov (2011): "Precautionary Price Stickiness," Working Paper 1122, Banco de España.

Devereux, M. B. And H. E. Siu (2007): "State Dependent Pricing and Business Cycle Asymmetries," International Economic Review, 48, 281-310.

Dhyne, E., C. Fuss, M. H. Pesaran, And P. Sevestre (2007): "Lumpy Price Adjustments: A Microeconometric Analysis," Working Paper 185, Banque de France. (2011a): "Lumpy Price Adjustments: A Microeconometric Analysis," Journal of Business $\mathcal{E}$ Economic Statistics, 29, 529-540.

(2011b): "The Supplement to "Lumpy Price Adjustments: A Microeconometric Analysis"," Journal of Business 83 Economic Statistics, 29, 529-540.

Dotsey, M., R. G. King, And A. L. Wolman (1999): "State-Dependent Pricing and the General Equilibrium Dynamics of Money and Output," Quarterly Journal of Economics, 114, 655-690.

Eberly, J. C. (1994): “Adjustment of Consumers' Durables Stocks: Evidence from Automobile Purchases," Journal of Political Economy, 102, 403-36. 
ECB (2009): "Wage Dynamics in Europe," Final Report, Wage Dynamics Network, European Central Bank.

Eden, B. (2001): "Inflation and Price Adjustment: An Analysis of Microdata," Review of Economic Dynamics, 4, 607-636.

Eichenbaum, M. S., N. Jaimovich, S. Rebelo, And J. Smith (2012): "How Frequent Are Small Price Changes?" Working Paper 17956, National Bureau of Economic Research.

Ellingsen, T., R. Friberg, and J. Hassler (2006): "Menu Costs and Asymmetric Price Adjustment," Discussion Paper 5749, CEPR.

Fehr, E. And L. Goette (2005): "Robustness and Real Consequences of Nominal Wage Rigidity," Journal of Monetary Economics, 52, 779-804.

Fougère, D., E. Gautier, And H. Le Bihan (2010): "Restaurant Prices and the Minimum Wage," Journal of Money, Credit and Banking, 42, 1199-1234.

Gagnon, E. (2009): "Price Setting During Low and High Inflation: Evidence from Mexico," Quarterly Journal of Economics, 124, 1221-1263.

Gautier, E. and H. Le Bihan (2011): "Time-varying (S,s) Band Models: Properties and Interpretation," Journal of Economic Dynamics and Control, 35, 394-412.

Golosov, M. And R. E. Lucas (2007): "Menu Costs and Phillips Curves," Journal of Political Economy, 115, 171-199.

Higo, M. And Y. Saita (2007): "Price Setting in Japan: Evidence from CPI Micro Data," Working Paper 07-E-20, Bank of Japan.

Honoré, B. E. (1992): "Trimmed LAD and Least Squares Estimation of Truncated and Censored Regression Models with Fixed Effects," Econometrica, 60, 533-565.

Honoré, B. E. And J. L. Powell (2005): "Pairwise Difference Estimation of Nonlinear Models," in Identification and Inference for Econometric Models. Essays in Honor of Thomas Rothenberg., ed. by D. W. K. Andrews and J. H. Stock, Cambridge University Press, chap. 22, 520-553. 
Karadi, P. And A. Reiff (2010): "Inflation Asymmetry, Menu Costs and Aggregation Bias - A Further Case for State Dependent Pricing," Working Paper 2010-3, Magyar Nemzeti Bank.

Kaufmann, D. (2009): "Price-Setting Behaviour in Switzerland: Evidence from CPI Micro Data," Swiss Journal of Economics and Statistics, 145, 293-349.

Kaufmann, D. And S. Lein (2011): "Sectoral Inflation Dynamics, Idiosyncratic Shocks and Monetary Policy,” Working Paper 2011-7, Swiss National Bank.

Kehoe, P. J. And V. Midrigan (2007): "Sales and the Real Effects of Monetary Policy," Working Paper 652, Federal Reserve Bank of Minneapolis.

Klenow, P. J. And O. Kryvtsov (2008): "State-Dependent or Time-Dependent Pricing: Does It Matter for Recent U.S. Inflation?" Quarterly Journal of Economics, 123.

Kuroda, S. And I. Yamamoto (2003): "The Impact of Downward Nominal Wage Rigidity on the Unemployment Rate: Quantitative Evidence from Japan," Monetary and Economic Studies, 21, 57-85.

Lein, S. M. (2010): "When Do Firms Adjust Prices? Evidence from Micro Panel Data," Journal of Monetary Economics, 57, 696-715.

Manski, C. (1987): "Semiparametric Analysis of Random Effects Linear Models from Binary Panel Data," Econometrica, 55, 357-62.

Midrigan, V. (2010): "Is Firm Pricing State or Time Dependent? Evidence from U.S. Manufacturing," Review of Economics and Statistics, 92, 643-656.

(2011): "Menu Costs, Multiproduct Firms, and Aggregate Fluctuations," Econometrica, 79, 1139-1180.

Nakamura, E. And J. Steinsson (2008): "Five Facts About Prices: A Reevaluation of Menu Cost Models," Quarterly Journal of Economics, 123.

(2010): "Monetary Non-Neutrality in a Multisector Menu Cost Model," The Quarterly Journal of Economics, 125, 961-1013. 
Peltzman, S. (2000): "Prices Rise Faster than They Fall," Journal of Political Economy, 108, 466-502.

Rasch, G. (1960): Probabilistic Models for Some Intelligence and Attainment Tests, Copenhagen: Denmarks Pædagogiske Institut.

Rosett, R. N. (1959): "A Statistical Model of Friction in Economics," Econometrica, $27,263-267$.

Sheshinski, E. And Y. Weiss (1977): "Inflation and Costs of Price Adjustment," Review of Economic Studies, 44, 287-303.

Tobin, J. (1972): "Inflation and Unemployment," American Economic Review, 62, 1-18.

Tsiddon, D. (1993): "The (Mis)Behaviour of the Aggregate Price Level," Review of Economic Studies, 60, 889-902.

UDRY, C. (1994): "Risk and Insurance in a Rural Credit Market: An Empirical Investigation in Northern Nigeria," Review of Economic Studies, 61, 495-526.

Zbaracki, M., M. Ritson, D. Levy, S. Dutta, And M. Bergen (2004): "Managerial and Customer Costs of Price Adjustment: Direct Evidence from Industrial Markets," Review of Economics and Statistics, 86, 514-533. 


\section{A Appendix}

A.1 Additional tables 


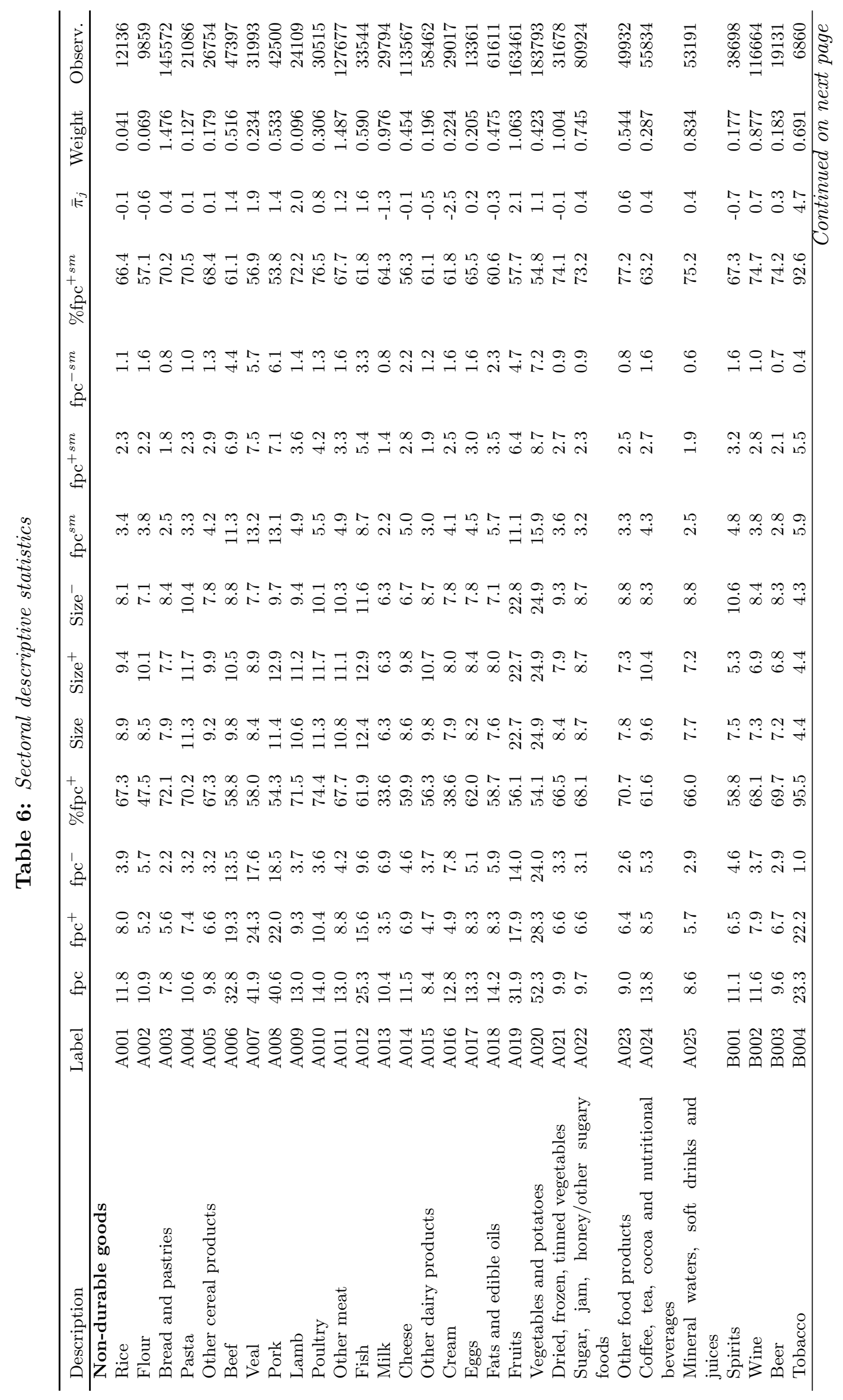




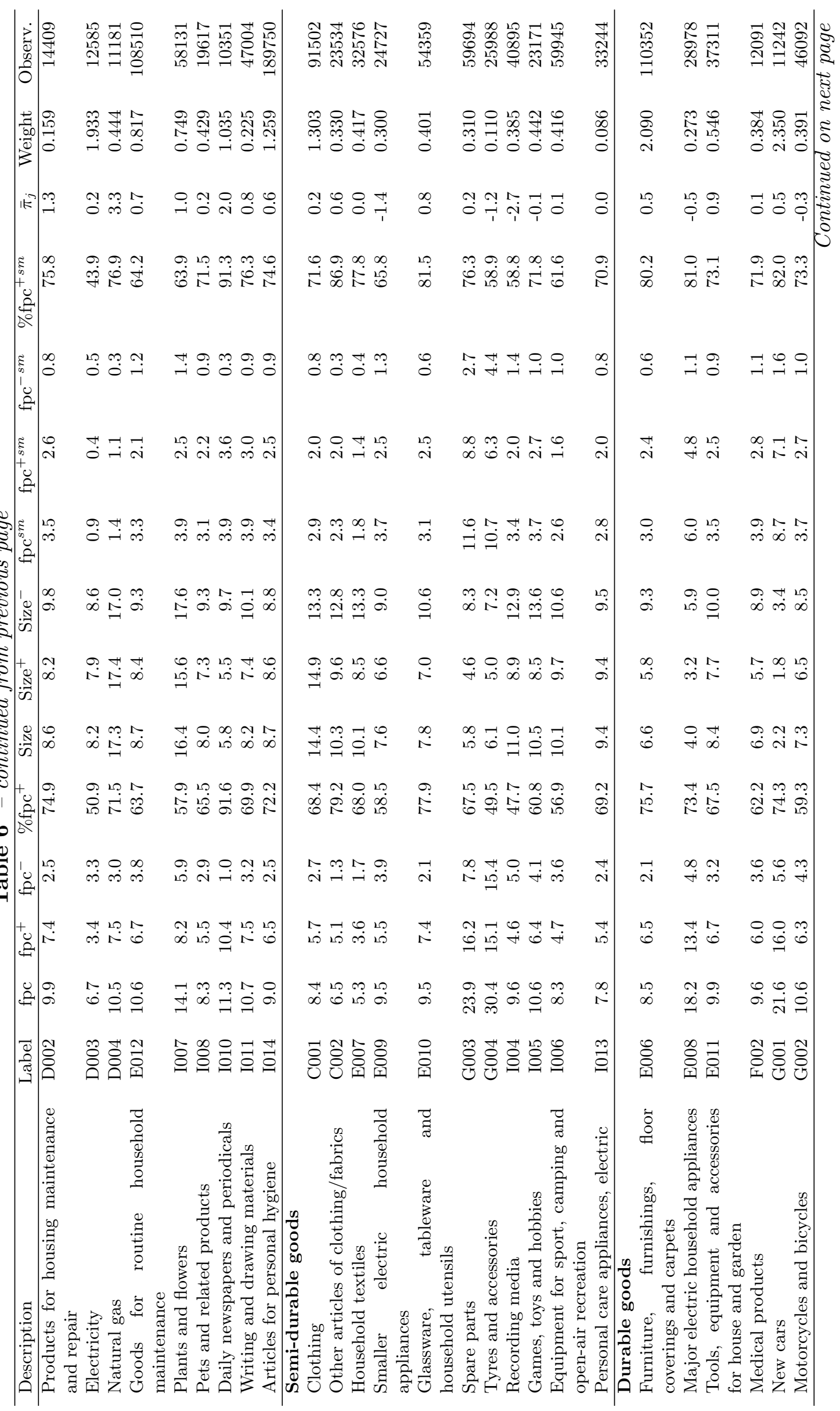




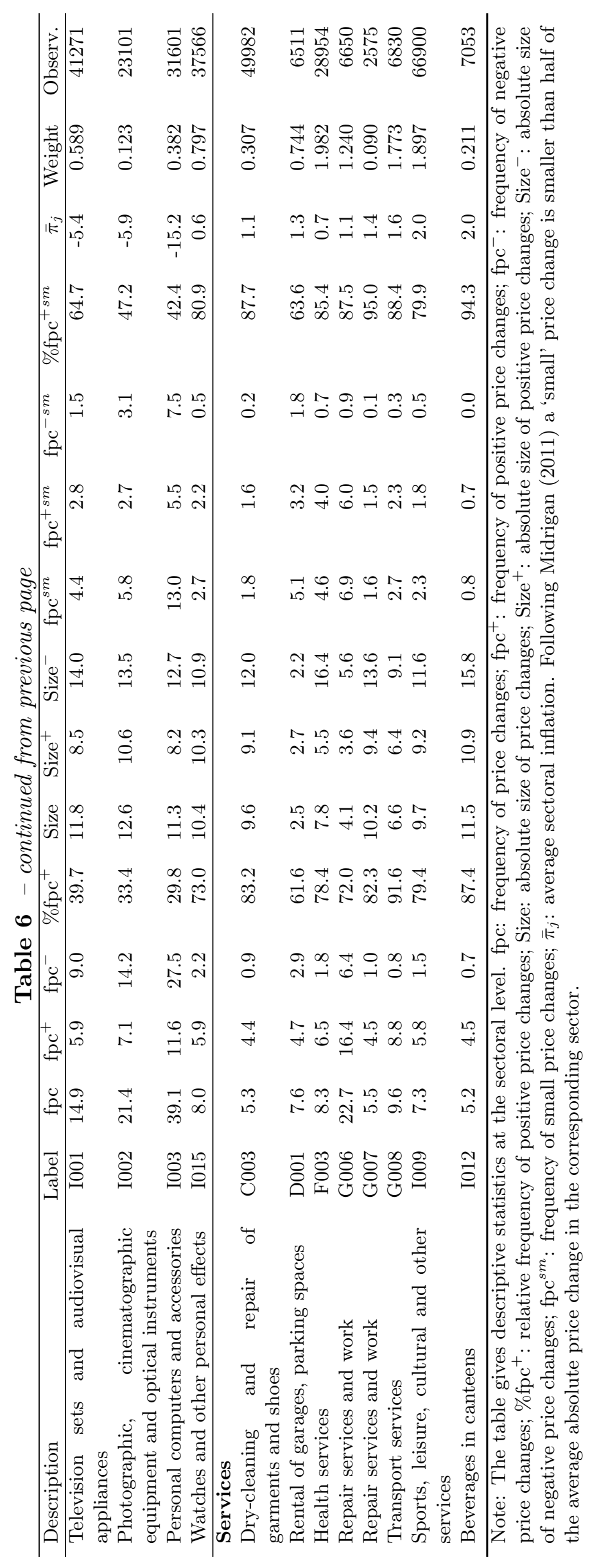

33 
Table 7: Estimates of desired price equation (complete results)

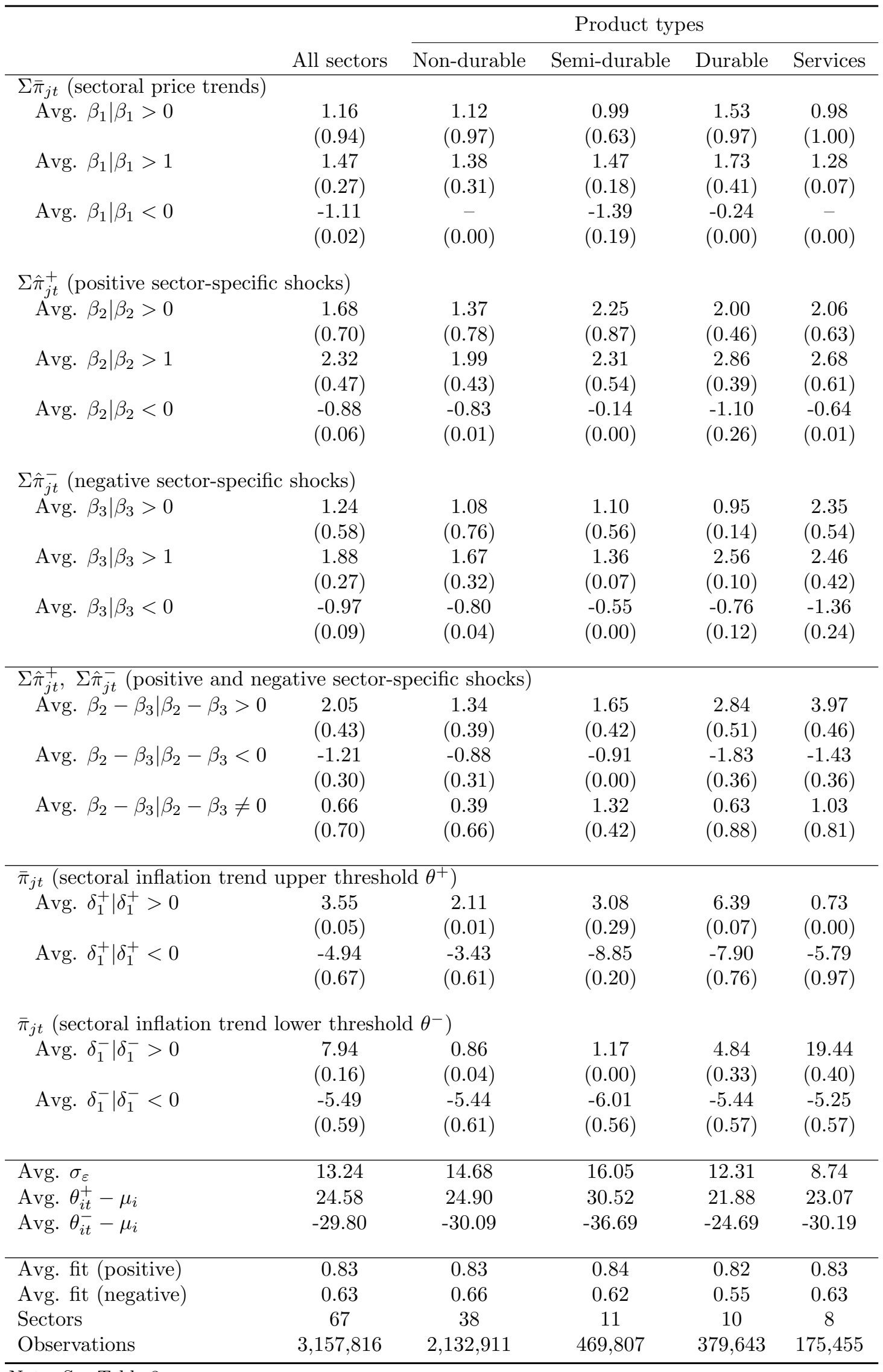

Note: See Table 3. 
Table 8: Estimates sector level

\begin{tabular}{|c|c|c|c|c|c|c|c|c|c|c|}
\hline & A001 & A002 & A003 & A004 & A005 & A006 & $\mathrm{A} 007$ & A008 & A009 & A010 \\
\hline$\sum_{i t}^{*} \bar{\pi}_{j t}$ & $\begin{array}{r}0.27 \\
{[0.46]}\end{array}$ & $\begin{array}{r}0.71^{* * *} \\
{[0.18]}\end{array}$ & $\begin{array}{r}1.10^{* * *} \\
{[0.07]}\end{array}$ & $\begin{array}{r}0.13 \\
{[0.20]}\end{array}$ & $\begin{array}{r}0.05 \\
{[0.49]}\end{array}$ & $\begin{array}{r}1.61^{* * *} \\
{[0.05]}\end{array}$ & $\begin{array}{r}1.25^{* * *} \\
{[0.04]}\end{array}$ & $\begin{array}{r}0.86^{* * *} \\
{[0.03]}\end{array}$ & $\begin{array}{r}1.02^{* * *} \\
{[0.10]}\end{array}$ & $\begin{array}{r}1.71^{* * *} \\
{[0.17]}\end{array}$ \\
\hline$\sum \hat{\pi}_{j t}^{+}$ & $\begin{array}{r}1.33^{* * *} \\
{[0.14]}\end{array}$ & $\begin{array}{r}2.05^{* * *} \\
{[0.48]}\end{array}$ & $\begin{array}{r}3.34^{* * *} \\
{[0.20]}\end{array}$ & $\begin{array}{r}1.54^{* * *} \\
{[0.18]}\end{array}$ & $\begin{array}{r}0.22 \\
{[0.49]}\end{array}$ & $\begin{array}{r}0.93^{* * *} \\
{[0.09]}\end{array}$ & $\begin{array}{r}0.97^{* * *} \\
{[0.13]}\end{array}$ & $\begin{array}{r}1.41^{* * *} \\
{[0.08]}\end{array}$ & $\begin{array}{r}1.81^{* * *} \\
{[0.54]}\end{array}$ & $\begin{array}{l}-0.37 \\
{[0.36]}\end{array}$ \\
\hline$\sum \hat{\pi}_{j t}^{-}$ & $\begin{array}{l}0.27^{*} \\
{[0.15]}\end{array}$ & $\begin{array}{r}1.98^{* * *} \\
{[0.42]}\end{array}$ & $\begin{array}{r}0.95^{* * *} \\
{[0.23]} \\
\end{array}$ & $\begin{array}{r}0.34 \\
{[0.28]} \\
\end{array}$ & $\begin{array}{r}0.27 \\
{[0.47]} \\
\end{array}$ & $\begin{array}{r}1.27^{* * *} \\
{[0.06]}\end{array}$ & $\begin{array}{r}1.23^{* * *} \\
{[0.07]} \\
\end{array}$ & $\begin{array}{r}0.65^{* * *} \\
{[0.04]}\end{array}$ & $\begin{array}{r}1.18^{* * *} \\
{[0.36]}\end{array}$ & $\begin{array}{r}1.31^{* * *} \\
{[0.45]}\end{array}$ \\
\hline$\sigma_{\varepsilon}$ & $\begin{array}{r}11.83^{* * *} \\
{[1.00]}\end{array}$ & $\begin{array}{r}11.41^{* * *} \\
{[1.16]}\end{array}$ & $\begin{array}{r}10.33^{* * *} \\
{[0.39]}\end{array}$ & $\begin{array}{r}18.10^{* * *} \\
{[1.43]}\end{array}$ & $\begin{array}{r}18.44^{* * *} \\
{[1.41]} \\
\end{array}$ & $\begin{array}{r}18.04^{* * *} \\
{[0.47]}\end{array}$ & $\begin{array}{r}15.15^{* * *} \\
{[0.53]}\end{array}$ & $\begin{array}{r}17.31^{* * *} \\
{[0.41]}\end{array}$ & $\begin{array}{r}19.58^{* * *} \\
{[1.25]}\end{array}$ & $\begin{array}{r}19.84^{* * *} \\
{[1.17]}\end{array}$ \\
\hline $\begin{array}{l}\theta_{i t}^{+} \\
\bar{\pi}_{j t}\end{array}$ & $\begin{array}{r}8.74^{* * *} \\
{[2.41]}\end{array}$ & $\begin{array}{r}-5.66^{* * *} \\
{[1.54]}\end{array}$ & $\begin{array}{r}-3.08^{* * *} \\
{[0.38]}\end{array}$ & $\begin{array}{r}-3.45^{* * *} \\
{[0.88]}\end{array}$ & $\begin{array}{r}-4.30^{* *} \\
{[2.19]}\end{array}$ & $\begin{array}{r}-4.89^{* * *} \\
{[0.41]}\end{array}$ & $\begin{array}{r}-1.87^{* * *} \\
{[0.31]}\end{array}$ & $\begin{array}{r}-1.92^{* * *} \\
{[0.25]}\end{array}$ & $\begin{array}{r}3.81^{* * *} \\
{[1.24]}\end{array}$ & $\begin{array}{l}-0.36 \\
{[1.40]}\end{array}$ \\
\hline$Q_{2}$ & $\begin{array}{r}-3.00^{* * *} \\
{[0.80]}\end{array}$ & $\begin{array}{r}4.13^{* * *} \\
{[1.17]}\end{array}$ & $\begin{array}{r}3.39^{* * *} \\
{[0.29]}\end{array}$ & $\begin{array}{l}1.70^{*} \\
{[0.89]}\end{array}$ & $\begin{array}{r}-2.10^{* *} \\
{[0.99]}\end{array}$ & $\begin{array}{l}-0.74 \\
{[0.49]}\end{array}$ & $\begin{array}{l}-0.08 \\
{[0.53]}\end{array}$ & $\begin{array}{r}-9.95^{* * *} \\
{[0.50]}\end{array}$ & $\begin{array}{l}-0.56 \\
{[0.80]}\end{array}$ & $\begin{array}{l}-0.27 \\
{[0.66]}\end{array}$ \\
\hline$Q_{3}$ & $\begin{array}{r}-2.45^{* * *} \\
{[0.81]}\end{array}$ & $\begin{array}{r}6.22^{* * *} \\
{[1.19]}\end{array}$ & $\begin{array}{r}4.39^{* * *} \\
{[0.31]}\end{array}$ & $\begin{array}{r}3.13^{* * *} \\
{[0.93]}\end{array}$ & $\begin{array}{l}-1.54 \\
{[0.99]}\end{array}$ & $\begin{array}{r}-4.18^{* * *} \\
{[0.47]}\end{array}$ & $\begin{array}{r}-6.79^{* * *} \\
{[0.60]}\end{array}$ & $\begin{array}{r}-2.61^{* * *} \\
{[0.47]}\end{array}$ & $\begin{array}{r}0.03 \\
{[0.81]}\end{array}$ & $\begin{array}{r}0.72 \\
{[0.70]}\end{array}$ \\
\hline$Q_{4}$ & $\begin{array}{r}-2.14^{* * *} \\
{[0.81]}\end{array}$ & $\begin{array}{r}7.05^{* * *} \\
{[1.25]}\end{array}$ & $\begin{array}{r}2.76^{* * *} \\
{[0.28]}\end{array}$ & $\begin{array}{c}1.90^{* *} \\
{[0.87]}\end{array}$ & $\begin{array}{r}-2.08^{* *} \\
{[0.97]}\end{array}$ & $\begin{array}{r}-4.27^{* * *} \\
{[0.45]}\end{array}$ & $\begin{array}{r}-13.50^{* * *} \\
{[0.74]}\end{array}$ & $\begin{array}{r}1.73^{* * *} \\
{[0.47]}\end{array}$ & $\begin{array}{l}1.55^{*} \\
{[0.79]}\end{array}$ & $\begin{array}{r}0.39 \\
{[0.68]}\end{array}$ \\
\hline vat $_{95}$ & $\begin{array}{r}-6.59^{* * *} \\
{[1.39]}\end{array}$ & $\begin{array}{l}-0.15 \\
{[3.35]}\end{array}$ & $\begin{array}{r}-5.91^{* * *} \\
{[0.81]}\end{array}$ & $\begin{array}{r}-10.68^{* * *} \\
{[1.65]}\end{array}$ & $\begin{array}{r}-21.92^{* * *} \\
{[2.85]}\end{array}$ & $\begin{array}{r}-20.06^{* * *} \\
{[1.51]}\end{array}$ & $\begin{array}{r}-8.70^{* * *} \\
{[1.58]}\end{array}$ & $\begin{array}{r}-7.84^{* * *} \\
{[1.78]}\end{array}$ & $\begin{array}{r}-10.45^{* * *} \\
{[2.05]}\end{array}$ & $\begin{array}{r}-6.20^{* * *} \\
{[1.57]}\end{array}$ \\
\hline vat $_{99}$ & $\begin{array}{r}-3.57^{* * *} \\
{[1.27]}\end{array}$ & $\begin{array}{r}1.49 \\
{[2.07]}\end{array}$ & $\begin{array}{r}-3.42^{* * *} \\
{[0.44]}\end{array}$ & $\begin{array}{r}2.37 \\
{[1.68]}\end{array}$ & $\begin{array}{r}-6.36^{* * *} \\
{[1.75]}\end{array}$ & $\begin{array}{r}5.02^{* * *} \\
{[1.25]}\end{array}$ & $\begin{array}{r}1.00 \\
{[1.52]}\end{array}$ & $\begin{array}{r}3.77^{* * *} \\
{[1.21]}\end{array}$ & $\begin{array}{c}5.04^{* *} \\
{[2.26]}\end{array}$ & $\begin{array}{r}0.56 \\
{[1.80]}\end{array}$ \\
\hline vat $_{01}$ & $\begin{array}{c}7.46^{* *} \\
{[3.78]} \\
\end{array}$ & $\begin{array}{r}1.62 \\
{[5.02]}\end{array}$ & $\begin{array}{r}-1.99^{* * *} \\
{[0.51]} \\
\end{array}$ & $\begin{array}{l}-0.76 \\
{[2.24]} \\
\end{array}$ & $\begin{array}{r}-8.61^{* * *} \\
{[2.43]} \\
\end{array}$ & $\begin{array}{r}-6.67^{* * *} \\
{[1.38]}\end{array}$ & $\begin{array}{r}-7.12^{* * *} \\
{[1.32]}\end{array}$ & $\begin{array}{r}-3.22^{* *} \\
{[1.27]} \\
\end{array}$ & $\begin{array}{l}-2.73 \\
{[2.37]}\end{array}$ & $\begin{array}{r}-12.04^{* * *} \\
{[1.62]}\end{array}$ \\
\hline $\begin{array}{l}\theta_{i t}^{-} \\
\bar{\pi}_{j t}\end{array}$ & $\begin{array}{r}3.19 \\
{[3.13]}\end{array}$ & $\begin{array}{r}-11.98^{* * *} \\
{[1.92]}\end{array}$ & $\begin{array}{r}-6.67^{* * *} \\
{[0.57]}\end{array}$ & $\begin{array}{l}-0.95 \\
{[1.59]}\end{array}$ & $\begin{array}{r}3.39 \\
{[2.81]}\end{array}$ & $\begin{array}{r}-3.82^{* * *} \\
{[0.44]}\end{array}$ & $\begin{array}{r}-3.40^{* * *} \\
{[0.39]}\end{array}$ & $\begin{array}{r}-2.76^{* * *} \\
{[0.26]}\end{array}$ & $\begin{array}{r}-4.65^{* *} \\
{[1.97]}\end{array}$ & $\begin{array}{l}-1.75 \\
{[2.74]}\end{array}$ \\
\hline$Q_{2}$ & $\begin{array}{r}-2.11^{*} \\
{[1.22]}\end{array}$ & $\begin{array}{r}-3.27^{* * *} \\
{[0.92]}\end{array}$ & $\begin{array}{r}-1.98^{* * *} \\
{[0.35]}\end{array}$ & $\begin{array}{r}0.09 \\
{[1.27]}\end{array}$ & $\begin{array}{r}1.21 \\
{[1.22]}\end{array}$ & $\begin{array}{r}3.23^{* * *} \\
{[0.51]}\end{array}$ & $\begin{array}{r}-3.19^{* * *} \\
{[0.47]}\end{array}$ & $\begin{array}{r}-9.19^{* * *} \\
{[0.61]}\end{array}$ & $\begin{array}{r}1.97 \\
{[1.24]}\end{array}$ & $\begin{array}{r}4.62^{* * *} \\
{[1.17]}\end{array}$ \\
\hline$Q_{3}$ & $\begin{array}{l}-1.74 \\
{[1.20]}\end{array}$ & $\begin{array}{r}-4.14^{* * *} \\
{[1.00]}\end{array}$ & $\begin{array}{r}-2.72^{* * *} \\
{[0.39]}\end{array}$ & $\begin{array}{l}-2.03 \\
{[1.37]}\end{array}$ & $\begin{array}{r}1.40 \\
{[1.19]}\end{array}$ & $\begin{array}{r}-2.90^{* * *} \\
{[0.57]}\end{array}$ & $\begin{array}{r}-10.51^{* * *} \\
{[0.71]}\end{array}$ & $\begin{array}{l}-0.17 \\
{[0.47]}\end{array}$ & $\begin{array}{l}2.25^{*} \\
{[1.27]}\end{array}$ & $\begin{array}{r}2.69^{* *} \\
{[1.21]}\end{array}$ \\
\hline$Q_{4}$ & $\begin{array}{l}-0.25 \\
{[1.04]}\end{array}$ & $\begin{array}{r}0.41 \\
{[0.74]}\end{array}$ & $\begin{array}{r}0.40 \\
{[0.31]}\end{array}$ & $\begin{array}{l}-0.88 \\
{[1.34]}\end{array}$ & $\begin{array}{r}2.95^{* *} \\
{[1.20]}\end{array}$ & $\begin{array}{r}-3.91^{* * *} \\
{[0.54]}\end{array}$ & $\begin{array}{r}-20.03^{* * *} \\
{[1.07]}\end{array}$ & $\begin{array}{r}4.21^{* * *} \\
{[0.48]}\end{array}$ & $\begin{array}{r}4.95^{* * *} \\
{[1.29]}\end{array}$ & $\begin{array}{r}4.02^{* * *} \\
{[1.19]}\end{array}$ \\
\hline vat $_{95}$ & $\begin{array}{r}0.23 \\
{[1.73]}\end{array}$ & $\begin{array}{r}17.45^{* * *} \\
{[4.31]}\end{array}$ & $\begin{array}{r}12.51^{* * *} \\
{[1.30]}\end{array}$ & $\begin{array}{l}-4.93 \\
{[3.18]}\end{array}$ & $\begin{array}{r}2.81 \\
{[3.01]}\end{array}$ & $\begin{array}{r}-6.34^{* * *} \\
{[1.37]}\end{array}$ & $\begin{array}{r}-11.81^{* * *} \\
{[1.59]}\end{array}$ & $\begin{array}{r}-8.93^{* * *} \\
{[1.52]}\end{array}$ & $\begin{array}{r}7.88^{* * *} \\
{[3.00]}\end{array}$ & $\begin{array}{r}4.87^{* *} \\
{[2.42]}\end{array}$ \\
\hline vat $_{99}$ & $\begin{array}{l}-2.49 \\
{[3.34]}\end{array}$ & $\begin{array}{r}-9.10^{*} \\
{[5.03]}\end{array}$ & $\begin{array}{r}0.04 \\
{[0.94]}\end{array}$ & $\begin{array}{l}-0.91 \\
{[3.11]}\end{array}$ & $\begin{array}{l}4.06^{*} \\
{[2.42]}\end{array}$ & $\begin{array}{r}5.39^{* * *} \\
{[0.95]}\end{array}$ & $\begin{array}{r}3.17^{* * *} \\
{[1.03]}\end{array}$ & $\begin{array}{r}1.12 \\
{[0.99]}\end{array}$ & $\begin{array}{r}12.83^{* * *} \\
{[2.39]}\end{array}$ & $\begin{array}{r}10.05^{* * *} \\
{[2.59]}\end{array}$ \\
\hline vat $_{01}$ & $\begin{array}{r}1.16 \\
{[4.15]}\end{array}$ & $\begin{array}{r}-3.07 \\
{[3.06]}\end{array}$ & $\begin{array}{r}2.19 \\
{[1.37]}\end{array}$ & $\begin{array}{r}4.04 \\
{[4.98]} \\
\end{array}$ & $\begin{array}{l}-4.52 \\
{[5.09]}\end{array}$ & $\begin{array}{r}0.09 \\
{[1.48]} \\
\end{array}$ & $\begin{array}{r}-2.67^{* *} \\
{[1.29]}\end{array}$ & $\begin{array}{r}-6.23^{* * *} \\
{[1.87]}\end{array}$ & $\begin{array}{r}6.18 \\
{[3.94]} \\
\end{array}$ & $\begin{array}{r}11.23^{* * *} \\
{[3.10]}\end{array}$ \\
\hline $\begin{array}{l}\text { Avg. } \theta_{i t}^{+}-\mu_{i} \\
\text { Avg. } \theta_{i t}^{-}-\mu_{i}\end{array}$ & $\begin{array}{r}20.83 \\
-24.80\end{array}$ & $\begin{array}{r}23.22 \\
-23.82 \\
\end{array}$ & $\begin{array}{r}21.92 \\
-30.59\end{array}$ & $\begin{array}{r}30.43 \\
-38.22\end{array}$ & $\begin{array}{r}29.83 \\
-38.96\end{array}$ & $\begin{array}{r}21.86 \\
-19.55\end{array}$ & $\begin{array}{r}16.14 \\
-14.36\end{array}$ & $\begin{array}{r}17.67 \\
-16.18\end{array}$ & $\begin{array}{r}30.10 \\
-38.39\end{array}$ & $\begin{array}{r}27.78 \\
-41.94\end{array}$ \\
\hline Fit (positive) & 0.75 & 0.73 & 0.89 & 0.80 & 0.84 & 0.55 & 0.67 & 0.77 & 0.71 & 0.80 \\
\hline Fit (negative) & 0.58 & 0.68 & 0.69 & 0.59 & 0.63 & 0.57 & 0.70 & 0.74 & 0.61 & 0.62 \\
\hline Estim. range & 12 & 12 & 12 & 12 & 12 & 12 & 12 & 12 & 12 & 12 \\
\hline Observations & 12136 & 9859 & 145572 & 21086 & 26754 & 47404 & 31993 & 42514 & 24109 & 30526 \\
\hline
\end{tabular}

Note: See Table 3. 
Table 9: Estimates sector level (contd.)

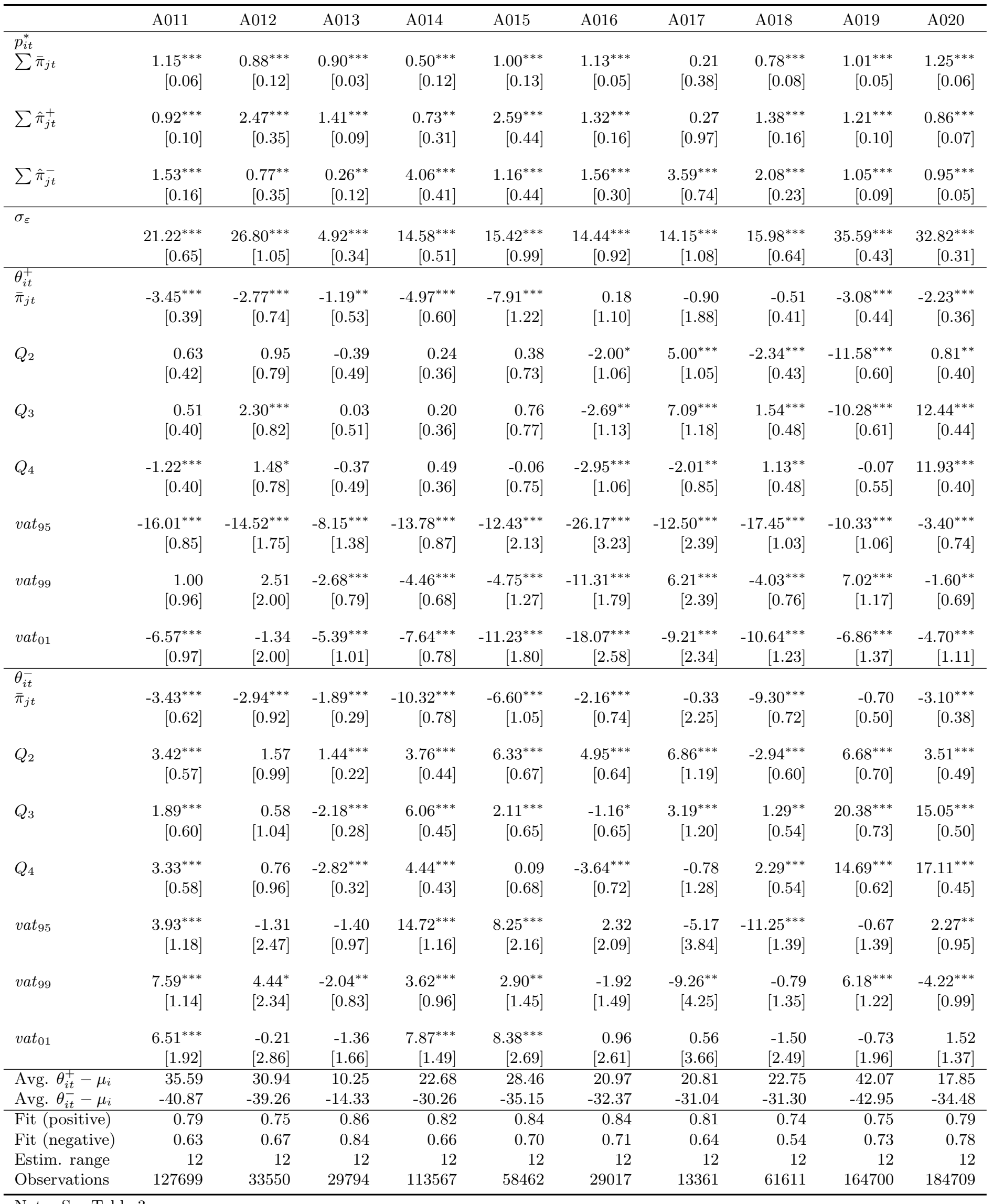


Table 10: Estimates sector level (contd.)

\begin{tabular}{|c|c|c|c|c|c|c|c|c|c|c|}
\hline & $\mathrm{A} 021$ & A022 & A023 & $\mathrm{A} 024$ & A025 & B001 & B002 & B003 & B004 & $\mathrm{C} 001$ \\
\hline$\sum_{i t}^{*} \bar{\pi}_{j t}$ & $\begin{array}{r}2.41^{* * *} \\
{[0.50]}\end{array}$ & $\begin{array}{r}0.97^{* * *} \\
{[0.10]}\end{array}$ & $\begin{array}{r}0.90^{* * *} \\
{[0.11]}\end{array}$ & $\begin{array}{r}0.59^{* * *} \\
{[0.05]}\end{array}$ & $\begin{array}{r}1.02^{* * *} \\
{[0.14]}\end{array}$ & $\begin{array}{r}0.29^{* *} \\
{[0.14]}\end{array}$ & $\begin{array}{r}0.86^{* * *} \\
{[0.09]}\end{array}$ & $\begin{array}{r}1.29^{* * *} \\
{[0.22]}\end{array}$ & $\begin{array}{r}0.90^{* * *} \\
{[0.02]}\end{array}$ & $\begin{array}{r}1.35^{* * *} \\
{[0.23]}\end{array}$ \\
\hline$\sum \hat{\pi}_{j t}^{+}$ & $\begin{array}{r}0.85 \\
{[0.57]}\end{array}$ & $\begin{array}{r}1.77^{* * *} \\
{[0.14]}\end{array}$ & $\begin{array}{r}1.26^{* * *} \\
{[0.28]}\end{array}$ & $\begin{array}{r}0.58^{* * *} \\
{[0.05]}\end{array}$ & $\begin{array}{r}0.69^{* * *} \\
{[0.23]}\end{array}$ & $\begin{array}{r}0.97^{* * *} \\
{[0.19]}\end{array}$ & $\begin{array}{r}1.55^{* * *} \\
{[0.19]}\end{array}$ & $\begin{array}{r}-1.59^{*} \\
{[0.86]}\end{array}$ & $\begin{array}{r}1.09^{* * *} \\
{[0.06]}\end{array}$ & $\begin{array}{r}1.80^{* * *} \\
{[0.30]}\end{array}$ \\
\hline$\sum \hat{\pi}_{j t}^{-}$ & $\begin{array}{r}0.00 \\
{[0.32]} \\
\end{array}$ & $\begin{array}{r}0.82^{* * *} \\
{[0.17]} \\
\end{array}$ & $\begin{array}{r}-0.85^{* * *} \\
{[0.22]} \\
\end{array}$ & $\begin{array}{r}1.07^{* * *} \\
{[0.08]}\end{array}$ & $\begin{array}{r}0.80^{* * *} \\
{[0.21]}\end{array}$ & $\begin{array}{r}1.09^{* * *} \\
{[0.16]}\end{array}$ & $\begin{array}{r}1.00^{* * *} \\
{[0.21]}\end{array}$ & $\begin{array}{r}0.45 \\
{[0.75]} \\
\end{array}$ & $\begin{array}{c}0.20^{*} \\
{[0.11]}\end{array}$ & $\begin{array}{r}1.25^{* * *} \\
{[0.25]}\end{array}$ \\
\hline$\sigma_{\varepsilon}$ & $\begin{array}{r}15.86^{* * *} \\
{[1.16]}\end{array}$ & $\begin{array}{r}12.26^{* * *} \\
{[0.44]}\end{array}$ & $\begin{array}{r}9.97^{* * *} \\
{[0.47]} \\
\end{array}$ & $\begin{array}{r}12.41^{* * *} \\
{[0.43]}\end{array}$ & $\begin{array}{r}11.17^{* * *} \\
{[0.54]}\end{array}$ & $\begin{array}{r}13.02^{* * *} \\
{[0.63]}\end{array}$ & $\begin{array}{r}12.41^{* * *} \\
{[0.32]}\end{array}$ & $\begin{array}{r}10.75^{* * *} \\
{[0.73]}\end{array}$ & $\begin{array}{r}3.64^{* * *} \\
{[0.29]}\end{array}$ & $\begin{array}{r}16.74^{* * *} \\
{[0.63]}\end{array}$ \\
\hline $\begin{array}{l}\theta_{i t}^{+} \\
\bar{\pi}_{j t}\end{array}$ & $\begin{array}{r}-10.49^{* * *} \\
{[3.17]}\end{array}$ & $\begin{array}{r}-4.43^{* * *} \\
{[0.49]}\end{array}$ & $\begin{array}{r}-4.32^{* * *} \\
{[0.61]}\end{array}$ & $\begin{array}{r}0.12 \\
{[0.20]}\end{array}$ & $\begin{array}{r}-2.01^{* * *} \\
{[0.58]}\end{array}$ & $\begin{array}{r}-3.82^{* * *} \\
{[0.68]}\end{array}$ & $\begin{array}{r}-2.13^{* * *} \\
{[0.51]}\end{array}$ & $\begin{array}{r}-4.14^{* * *} \\
{[1.23]}\end{array}$ & $\begin{array}{c}-0.14 \\
{[0.20]}\end{array}$ & $\begin{array}{r}4.71^{* * *} \\
{[1.02]}\end{array}$ \\
\hline$Q_{2}$ & $\begin{array}{r}3.60^{* * *} \\
{[0.68]}\end{array}$ & $\begin{array}{r}-1.88^{* * *} \\
{[0.34]}\end{array}$ & $\begin{array}{l}0.68^{*} \\
{[0.35]}\end{array}$ & $\begin{array}{r}-1.40^{* * *} \\
{[0.40]}\end{array}$ & $\begin{array}{l}-0.43 \\
{[0.40]}\end{array}$ & $\begin{array}{r}0.38 \\
{[0.52]}\end{array}$ & $\begin{array}{r}-2.03^{* * *} \\
{[0.27]}\end{array}$ & $\begin{array}{r}3.14^{* * *} \\
{[0.59]}\end{array}$ & $\begin{array}{r}0.72^{* * *} \\
{[0.20]}\end{array}$ & $\begin{array}{r}-4.83^{* * *} \\
{[0.51]}\end{array}$ \\
\hline$Q_{3}$ & $\begin{array}{r}4.26^{* * *} \\
{[0.72]}\end{array}$ & $\begin{array}{r}-0.90^{* *} \\
{[0.35]}\end{array}$ & $\begin{array}{r}1.29^{* * *} \\
{[0.35]}\end{array}$ & $\begin{array}{r}-1.96^{* * *} \\
{[0.41]}\end{array}$ & $\begin{array}{r}1.13^{* * *} \\
{[0.43]}\end{array}$ & $\begin{array}{c}1.18^{* *} \\
{[0.54]}\end{array}$ & $\begin{array}{r}-1.30^{* * *} \\
{[0.26]}\end{array}$ & $\begin{array}{r}4.74^{* * *} \\
{[0.66]}\end{array}$ & $\begin{array}{r}0.94^{* * *} \\
\quad[0.21]\end{array}$ & $\begin{array}{r}1.15^{* *} \\
{[0.52]}\end{array}$ \\
\hline$Q_{4}$ & $\begin{array}{r}4.02^{* * *} \\
{[0.69]}\end{array}$ & $\begin{array}{r}0.43 \\
{[0.37]}\end{array}$ & $\begin{array}{r}1.73^{* * *} \\
{[0.36]}\end{array}$ & $\begin{array}{r}-0.98^{* *} \\
{[0.42]}\end{array}$ & $\begin{array}{r}0.50 \\
{[0.42]}\end{array}$ & $\begin{array}{r}2.21^{* * *} \\
{[0.55]}\end{array}$ & $\begin{array}{r}-0.51^{*} \\
{[0.27]}\end{array}$ & $\begin{array}{r}5.42^{* * *} \\
{[0.75]}\end{array}$ & $\begin{array}{r}1.54^{* * *} \\
{[0.24]}\end{array}$ & $\begin{array}{r}-7.97^{* * *} \\
{[0.55]}\end{array}$ \\
\hline vat $_{95}$ & $\begin{array}{r}-21.31^{* * *} \\
{[2.18]}\end{array}$ & $\begin{array}{r}-9.50^{* * *} \\
{[0.69]}\end{array}$ & $\begin{array}{r}-14.30^{* * *} \\
{[1.12]}\end{array}$ & $\begin{array}{r}-9.76^{* * *} \\
{[0.76]}\end{array}$ & $\begin{array}{r}-11.03^{* * *} \\
{[0.78]}\end{array}$ & $\begin{array}{r}1.25 \\
{[1.57]}\end{array}$ & $\begin{array}{r}-5.39^{* * *} \\
{[0.52]}\end{array}$ & $\begin{array}{r}-4.97^{* * *} \\
{[1.29]}\end{array}$ & $\begin{array}{r}-2.77^{* * *} \\
{[0.55]}\end{array}$ & $\begin{array}{r}-8.38^{* * *} \\
{[0.92]}\end{array}$ \\
\hline vat $_{99}$ & $\begin{array}{r}-4.87^{* * *} \\
{[1.80]}\end{array}$ & $\begin{array}{r}-2.67^{* * *} \\
{[0.72]}\end{array}$ & $\begin{array}{r}-5.79^{* * *} \\
{[0.85]}\end{array}$ & $\begin{array}{r}-5.61^{* * *} \\
{[0.73]}\end{array}$ & $\begin{array}{r}-5.72^{* * *} \\
{[0.84]}\end{array}$ & $\begin{array}{r}-10.85^{* * *} \\
{[1.13]}\end{array}$ & $\begin{array}{r}-10.17^{* * *} \\
{[0.49]}\end{array}$ & $\begin{array}{r}-3.80^{* * *} \\
{[1.07]}\end{array}$ & $\begin{array}{r}-7.53^{* * *} \\
{[1.09]}\end{array}$ & $\begin{array}{r}-3.59^{* * *} \\
{[0.95]}\end{array}$ \\
\hline vat $_{01}$ & $\begin{array}{r}-6.22^{* * *} \\
{[1.18]}\end{array}$ & $\begin{array}{r}-5.85^{* * *} \\
{[0.77]} \\
\end{array}$ & $\begin{array}{r}-5.31^{* * *} \\
{[0.64]} \\
\end{array}$ & $\begin{array}{r}-4.49^{* * *} \\
{[1.04]} \\
\end{array}$ & $\begin{array}{r}-6.89^{* * *} \\
{[0.88]}\end{array}$ & $\begin{array}{l}-1.22 \\
{[1.23]}\end{array}$ & $\begin{array}{r}-7.16^{* * *} \\
{[0.61]} \\
\end{array}$ & $\begin{array}{r}-5.92^{* * *} \\
{[1.25]} \\
\end{array}$ & $\begin{array}{r}-5.71^{* * *} \\
{[0.64]}\end{array}$ & $\begin{array}{r}2.70 \\
{[1.71]} \\
\end{array}$ \\
\hline $\begin{array}{l}\theta_{i t}^{-} \\
\bar{\pi}_{j t}\end{array}$ & $\begin{array}{r}-13.35^{* * *} \\
{[4.45]}\end{array}$ & $\begin{array}{r}0.14 \\
{[0.71]}\end{array}$ & $\begin{array}{l}-1.47 \\
{[0.94]}\end{array}$ & $\begin{array}{r}-1.66^{* * *} \\
{[0.27]}\end{array}$ & $\begin{array}{l}-0.44 \\
{[0.93]}\end{array}$ & $\begin{array}{r}-5.49^{* * *} \\
{[0.84]}\end{array}$ & $\begin{array}{c}1.52^{* *} \\
{[0.72]}\end{array}$ & $\begin{array}{r}-1.96 \\
{[1.77]}\end{array}$ & $\begin{array}{l}-1.24 \\
{[1.02]}\end{array}$ & $\begin{array}{r}-7.00^{* * *} \\
{[1.66]}\end{array}$ \\
\hline$Q_{2}$ & $\begin{array}{l}-0.09 \\
{[0.84]}\end{array}$ & $\begin{array}{c}-0.41 \\
{[0.46]}\end{array}$ & $\begin{array}{r}-0.87^{*} \\
{[0.49]}\end{array}$ & $\begin{array}{l}-0.13 \\
{[0.43]}\end{array}$ & $\begin{array}{l}-0.40 \\
{[0.51]}\end{array}$ & $\begin{array}{c}1.56^{* *} \\
{[0.67]}\end{array}$ & $\begin{array}{r}0.31 \\
{[0.37]}\end{array}$ & $\begin{array}{l}-0.90 \\
{[0.85]}\end{array}$ & $\begin{array}{r}3.36^{* * *} \\
{[1.13]}\end{array}$ & $\begin{array}{r}5.73^{* * *} \\
{[0.71]}\end{array}$ \\
\hline$Q_{3}$ & $\begin{array}{r}-1.52^{*} \\
{[0.90]}\end{array}$ & $\begin{array}{l}-0.33 \\
{[0.46]}\end{array}$ & $\begin{array}{r}-1.66^{* * *} \\
{[0.49]}\end{array}$ & $\begin{array}{r}-1.40^{* * *} \\
{[0.45]}\end{array}$ & $\begin{array}{l}-0.79 \\
{[0.52]}\end{array}$ & $\begin{array}{r}4.21^{* * *} \\
{[0.64]}\end{array}$ & $\begin{array}{r}0.09 \\
{[0.36]}\end{array}$ & $\begin{array}{l}-0.10 \\
{[0.85]}\end{array}$ & $\begin{array}{l}-1.39 \\
{[1.39]}\end{array}$ & $\begin{array}{l}1.35^{*} \\
{[0.75]}\end{array}$ \\
\hline$Q_{4}$ & $\begin{array}{r}-0.96 \\
{[0.90]}\end{array}$ & $\begin{array}{l}-0.19 \\
{[0.43]}\end{array}$ & $\begin{array}{r}-1.24^{* * *} \\
{[0.48]}\end{array}$ & $\begin{array}{r}1.08^{* * *} \\
{[0.39]}\end{array}$ & $\begin{array}{l}-0.57 \\
{[0.53]}\end{array}$ & $\begin{array}{r}4.31^{* * *} \\
{[0.66]}\end{array}$ & $\begin{array}{r}0.42 \\
{[0.36]}\end{array}$ & $\begin{array}{r}-0.97 \\
{[0.87]}\end{array}$ & $\begin{array}{r}0.02 \\
{[1.33]}\end{array}$ & $\begin{array}{r}7.03^{* * *} \\
{[0.71]}\end{array}$ \\
\hline vat $_{95}$ & $\begin{array}{l}-1.37 \\
{[2.97]}\end{array}$ & $\begin{array}{r}2.29^{* *} \\
{[0.97]}\end{array}$ & $\begin{array}{r}0.11 \\
{[2.62]}\end{array}$ & $\begin{array}{r}-2.61^{*} \\
{[1.54]}\end{array}$ & $\begin{array}{r}0.50 \\
{[1.11]}\end{array}$ & $\begin{array}{r}10.20^{* * *} \\
{[2.09]}\end{array}$ & $\begin{array}{r}3.66^{* * *} \\
{[0.69]}\end{array}$ & $\begin{array}{r}2.83 \\
{[1.93]}\end{array}$ & $\begin{array}{r}1.51 \\
{[1.58]}\end{array}$ & $\begin{array}{r}2.37 \\
{[1.64]}\end{array}$ \\
\hline vat $_{99}$ & $\begin{array}{r}2.66 \\
{[3.29]}\end{array}$ & $\begin{array}{r}0.62 \\
{[1.12]}\end{array}$ & $\begin{array}{r}0.07 \\
{[2.00]}\end{array}$ & $\begin{array}{l}-1.46 \\
{[1.06]}\end{array}$ & $\begin{array}{l}-0.29 \\
{[1.29]}\end{array}$ & $\begin{array}{r}0.75 \\
{[1.88]}\end{array}$ & $\begin{array}{r}0.52 \\
{[0.83]}\end{array}$ & $\begin{array}{l}3.15^{*} \\
{[1.88]}\end{array}$ & $\begin{array}{r}-32.12^{* * *} \\
{[2.90]}\end{array}$ & $\begin{array}{r}1.46 \\
{[1.59]}\end{array}$ \\
\hline vat $_{01}$ & $\begin{array}{r}1.20 \\
{[2.30]} \\
\end{array}$ & $\begin{array}{l}-0.16 \\
{[1.61]}\end{array}$ & $\begin{array}{r}-1.64 \\
{[1.35]}\end{array}$ & $\begin{array}{c}4.11^{* * *} \\
{[1.38]}\end{array}$ & $\begin{array}{r}-1.31 \\
{[1.88]}\end{array}$ & $\begin{array}{r}7.22^{* * *} \\
{[1.97]}\end{array}$ & $\begin{array}{r}0.71 \\
{[1.12]} \\
\end{array}$ & $\begin{array}{r}2.68 \\
{[2.37]}\end{array}$ & $\begin{array}{l}-2.31 \\
{[2.76]}\end{array}$ & $\begin{array}{r}2.62 \\
{[2.92]}\end{array}$ \\
\hline $\begin{array}{l}\text { Avg. } \theta_{i t}^{+}-\mu_{i} \\
\text { Avg. } \theta_{i t}^{-}-\mu_{i}\end{array}$ & $\begin{array}{r}26.61 \\
-36.12\end{array}$ & $\begin{array}{r}21.84 \\
-29.89\end{array}$ & $\begin{array}{r}20.16 \\
-25.81\end{array}$ & $\begin{array}{r}17.87 \\
-29.26\end{array}$ & $\begin{array}{r}21.48 \\
-26.97\end{array}$ & $\begin{array}{r}25.38 \\
-25.85\end{array}$ & $\begin{array}{r}20.76 \\
-27.70\end{array}$ & $\begin{array}{r}18.25 \\
-27.74\end{array}$ & $\begin{array}{r}11.79 \\
-12.61\end{array}$ & $\begin{array}{r}31.44 \\
-41.14\end{array}$ \\
\hline Fit (positive) & 0.85 & 0.84 & 0.88 & 0.84 & 0.89 & 0.78 & 0.80 & 0.88 & 0.80 & 0.84 \\
\hline Fit (negative) & 0.62 & 0.56 & 0.53 & 0.71 & 0.59 & 0.70 & 0.52 & 0.61 & 0.59 & 0.65 \\
\hline Estim. range & 12 & 12 & 12 & 12 & 12 & 12 & 12 & 12 & 12 & 12 \\
\hline Observations & 31678 & 80924 & 49932 & 55834 & 53191 & 38698 & 116664 & 19131 & 6860 & 91598 \\
\hline
\end{tabular}

Note: See Table 3. 
Table 11: Estimates sector level (contd.)

\begin{tabular}{|c|c|c|c|c|c|c|c|c|c|c|}
\hline & $\mathrm{C} 002$ & $\mathrm{C} 003$ & D001 & D002 & D003 & D004 & E006 & E007 & E008 & E009 \\
\hline$\sum_{i t}^{*} \bar{\pi}_{j t}$ & $\begin{array}{r}0.58^{* * *} \\
{[0.16]}\end{array}$ & $\begin{array}{r}1.37^{* * *} \\
{[0.10]}\end{array}$ & $\begin{array}{r}0.61^{* * *} \\
{[0.20]}\end{array}$ & $\begin{array}{r}0.45^{* * *} \\
{[0.17]}\end{array}$ & $\begin{array}{r}0.85^{* * *} \\
{[0.09]}\end{array}$ & $\begin{array}{r}0.57^{* * *} \\
{[0.07]}\end{array}$ & $\begin{array}{r}1.95^{* * *} \\
{[0.15]}\end{array}$ & $\begin{array}{c}-1.00^{*} \\
{[0.60]}\end{array}$ & $\begin{array}{l}-0.24 \\
{[0.20]}\end{array}$ & $\begin{array}{r}0.13 \\
{[0.17]}\end{array}$ \\
\hline$\sum \hat{\pi}_{j t}^{+}$ & $\begin{array}{r}1.39^{* * *} \\
{[0.31]}\end{array}$ & $\begin{array}{l}-0.21 \\
{[0.54]}\end{array}$ & $\begin{array}{l}-0.53 \\
{[0.43]}\end{array}$ & $\begin{array}{r}2.16^{* * *} \\
{[0.47]}\end{array}$ & $\begin{array}{r}0.92^{* * *} \\
\quad[0.19]\end{array}$ & $\begin{array}{r}1.90^{* * *} \\
{[0.15]}\end{array}$ & $\begin{array}{r}-1.31^{* * *} \\
{[0.32]}\end{array}$ & $\begin{array}{r}4.84^{* * *} \\
{[1.03]}\end{array}$ & $\begin{array}{r}0.21 \\
{[0.43]}\end{array}$ & $\begin{array}{r}1.85^{* * *} \\
{[0.61]}\end{array}$ \\
\hline$\sum \hat{\pi}_{j t}^{-}$ & $\begin{array}{r}-0.10 \\
{[0.32]} \\
\end{array}$ & $\begin{array}{r}0.87^{* * *} \\
{[0.29]}\end{array}$ & $\begin{array}{c}1.26^{* *} \\
{[0.49]} \\
\end{array}$ & $\begin{array}{r}0.06 \\
{[0.31]} \\
\end{array}$ & $\begin{array}{r}1.75^{* * *} \\
{[0.14]}\end{array}$ & $\begin{array}{r}0.71^{* * *} \\
{[0.20]}\end{array}$ & $\begin{array}{r}0.25 \\
{[0.37]} \\
\end{array}$ & $\begin{array}{l}1.39^{*} \\
{[0.73]}\end{array}$ & $\begin{array}{r}0.98^{* * *} \\
{[0.29]}\end{array}$ & $\begin{array}{r}1.85^{* * *} \\
{[0.42]}\end{array}$ \\
\hline$\sigma_{\varepsilon}$ & $\begin{array}{r}12.62^{* * *} \\
{[1.55]} \\
\end{array}$ & $\begin{array}{r}9.15^{* * *} \\
{[0.66]} \\
\end{array}$ & $\begin{array}{r}5.01^{* * *} \\
{[0.99]}\end{array}$ & $\begin{array}{r}12.69^{* * *} \\
{[0.99]}\end{array}$ & $\begin{array}{r}5.13^{* * *} \\
{[0.35]}\end{array}$ & $\begin{array}{r}11.27^{* * *} \\
{[0.67]}\end{array}$ & $\begin{array}{r}10.90^{* * *} \\
{[0.40]}\end{array}$ & $\begin{array}{r}12.57^{* * *} \\
{[0.83]}\end{array}$ & $\begin{array}{r}11.60^{* * *} \\
{[0.58]}\end{array}$ & $\begin{array}{r}15.80^{* * *} \\
{[1.13]}\end{array}$ \\
\hline $\begin{array}{l}\theta_{i t}^{+} \\
\bar{\pi}_{j t}\end{array}$ & $\begin{array}{r}0.97 \\
{[0.87]}\end{array}$ & $\begin{array}{r}-1.77^{* *} \\
{[0.87]}\end{array}$ & $\begin{array}{l}-0.78 \\
{[2.46]}\end{array}$ & $\begin{array}{r}5.72^{* * *} \\
{[1.30]}\end{array}$ & $\begin{array}{r}-2.75^{* * *} \\
{[0.58]}\end{array}$ & $\begin{array}{r}-4.70^{* * *} \\
{[0.61]}\end{array}$ & $\begin{array}{r}-6.79^{* * *} \\
{[1.04]}\end{array}$ & $\begin{array}{r}-14.47^{* * *} \\
{[4.01]}\end{array}$ & $\begin{array}{r}-3.97^{* * *} \\
{[1.20]}\end{array}$ & $\begin{array}{r}-13.42^{* * *} \\
{[3.45]}\end{array}$ \\
\hline$Q_{2}$ & $\begin{array}{r}-3.08^{* * *} \\
{[0.87]}\end{array}$ & $\begin{array}{r}1.28^{* * *} \\
{[0.37]}\end{array}$ & $\begin{array}{l}-0.96 \\
{[0.71]}\end{array}$ & $\begin{array}{c}1.94^{* *} \\
{[0.75]}\end{array}$ & $\begin{array}{c}3.91^{* * *} \\
\quad[1.12]\end{array}$ & $\begin{array}{r}10.24^{* * *} \\
{[1.61]}\end{array}$ & $\begin{array}{r}1.48^{* * *} \\
{[0.27]}\end{array}$ & $\begin{array}{r}5.97^{* * *} \\
{[0.87]}\end{array}$ & $\begin{array}{r}9.63^{* * *} \\
{[0.61]}\end{array}$ & $\begin{array}{r}8.05^{* * *} \\
{[0.90]}\end{array}$ \\
\hline$Q_{3}$ & $\begin{array}{l}-0.56 \\
{[0.80]}\end{array}$ & $\begin{array}{r}4.22^{* * *} \\
{[0.54]}\end{array}$ & $\begin{array}{r}0.70 \\
{[0.64]}\end{array}$ & $\begin{array}{r}2.88^{* * *} \\
{[0.77]}\end{array}$ & $\begin{array}{r}10.09^{* * *} \\
{[1.54]}\end{array}$ & $\begin{array}{r}13.19^{* * *} \\
{[1.77]}\end{array}$ & $\begin{array}{r}3.27^{* * *} \\
{[0.30]}\end{array}$ & $\begin{array}{r}1.98^{* * *} \\
{[0.71]}\end{array}$ & $\begin{array}{r}14.26^{* * *} \\
{[0.81]}\end{array}$ & $\begin{array}{r}8.58^{* * *} \\
{[0.92]}\end{array}$ \\
\hline$Q_{4}$ & $\begin{array}{r}-3.88^{* * *} \\
{[0.90]}\end{array}$ & $\begin{array}{r}3.79^{* * *} \\
{[0.50]}\end{array}$ & $\begin{array}{r}-1.57^{*} \\
{[0.90]}\end{array}$ & $\begin{array}{r}3.81^{* * *} \\
{[0.90]}\end{array}$ & $\begin{array}{r}-2.34^{* * *} \\
{[0.79]}\end{array}$ & $\begin{array}{l}-1.37 \\
{[1.04]}\end{array}$ & $\begin{array}{r}6.88^{* * *} \\
{[0.40]}\end{array}$ & $\begin{array}{r}5.21^{* * *} \\
{[0.86]}\end{array}$ & $\begin{array}{r}17.18^{* * *} \\
{[1.01]}\end{array}$ & $\begin{array}{r}7.72^{* * *} \\
{[0.95]}\end{array}$ \\
\hline vat $_{95}$ & $\begin{array}{r}-11.17^{* * *} \\
{[1.80]}\end{array}$ & $\begin{array}{r}-4.85^{* * *} \\
{[0.99]}\end{array}$ & $\begin{array}{r}-2.92^{*} \\
{[1.62]}\end{array}$ & $\begin{array}{r}-4.27^{* *} \\
{[1.67]}\end{array}$ & $\begin{array}{l}-0.02 \\
{[2.66]}\end{array}$ & $\begin{array}{r}-22.70^{* * *} \\
{[4.08]}\end{array}$ & $\begin{array}{r}-4.69^{* * *} \\
{[0.46]}\end{array}$ & $\begin{array}{l}-2.33 \\
{[1.55]}\end{array}$ & $\begin{array}{l}-0.45 \\
{[1.66]}\end{array}$ & $\begin{array}{r}1.64 \\
{[2.14]}\end{array}$ \\
\hline vat $_{99}$ & $\begin{array}{r}-11.21^{* * *} \\
{[1.79]}\end{array}$ & $\begin{array}{r}-7.89^{* * *} \\
{[0.85]}\end{array}$ & $\begin{array}{r}2.16 \\
{[1.96]}\end{array}$ & $\begin{array}{r}-7.86^{* * *} \\
{[1.63]}\end{array}$ & $\begin{array}{r}-5.13^{* * *} \\
{[1.30]}\end{array}$ & $\begin{array}{l}-0.38 \\
{[3.34]}\end{array}$ & $\begin{array}{r}-7.36^{* * *} \\
{[0.57]}\end{array}$ & $\begin{array}{r}-8.37^{* * *} \\
{[1.37]}\end{array}$ & $\begin{array}{r}-2.91^{* * *} \\
{[0.86]}\end{array}$ & $\begin{array}{r}-5.24^{* * *} \\
{[1.55]}\end{array}$ \\
\hline vat $_{01}$ & $\begin{array}{r}-6.64^{* * *} \\
{[1.86]} \\
\end{array}$ & $\begin{array}{r}-2.39^{* * *} \\
{[0.72]}\end{array}$ & $\begin{array}{l}-2.70 \\
{[1.87]} \\
\end{array}$ & $\begin{array}{l}-0.86 \\
{[2.47]} \\
\end{array}$ & $\begin{array}{r}51.61^{* * *} \\
{[3.55]} \\
\end{array}$ & $\begin{array}{r}-2.83^{*} \\
{[1.68]} \\
\end{array}$ & $\begin{array}{r}-5.08^{* * *} \\
{[0.55]}\end{array}$ & $\begin{array}{r}-3.31^{* *} \\
{[1.39]}\end{array}$ & $\begin{array}{r}-3.92^{* * *} \\
{[1.02]}\end{array}$ & $\begin{array}{l}-0.55 \\
{[1.59]}\end{array}$ \\
\hline $\begin{array}{l}\theta_{i t}^{-} \\
\bar{\pi}_{j t}\end{array}$ & $\begin{array}{l}-1.08 \\
{[1.55]}\end{array}$ & $\begin{array}{r}-5.87^{* * *} \\
{[1.89]}\end{array}$ & $\begin{array}{r}-6.82^{* * *} \\
{[2.34]}\end{array}$ & $\begin{array}{r}-4.34^{* *} \\
{[1.87]}\end{array}$ & $\begin{array}{r}-1.73^{* * *} \\
{[0.54]}\end{array}$ & $\begin{array}{r}-1.22^{* * *} \\
{[0.44]}\end{array}$ & $\begin{array}{r}5.66^{* * *} \\
{[1.70]}\end{array}$ & $\begin{array}{r}-14.67^{* *} \\
{[6.24]}\end{array}$ & $\begin{array}{r}-9.25^{* * *} \\
{[1.67]}\end{array}$ & $\begin{array}{r}-9.54^{* *} \\
{[4.40]}\end{array}$ \\
\hline$Q_{2}$ & $\begin{array}{l}2.59^{*} \\
{[1.32]}\end{array}$ & $\begin{array}{r}0.92 \\
{[0.84]}\end{array}$ & $\begin{array}{l}-0.06 \\
{[0.70]}\end{array}$ & $\begin{array}{r}-2.47^{* *} \\
{[1.24]}\end{array}$ & $\begin{array}{r}-1.48^{* *} \\
{[0.58]}\end{array}$ & $\begin{array}{r}-7.92^{* * *} \\
{[1.61]}\end{array}$ & $\begin{array}{l}-0.43 \\
{[0.44]}\end{array}$ & $\begin{array}{r}-3.66^{* * *} \\
{[1.12]}\end{array}$ & $\begin{array}{r}0.15 \\
{[0.56]}\end{array}$ & $\begin{array}{l}-0.96 \\
{[0.95]}\end{array}$ \\
\hline$Q_{3}$ & $\begin{array}{l}-0.97 \\
{[1.48]}\end{array}$ & $\begin{array}{r}-2.06^{* *} \\
{[1.03]}\end{array}$ & $\begin{array}{r}0.56 \\
{[0.68]}\end{array}$ & $\begin{array}{l}-1.72 \\
{[1.19]}\end{array}$ & $\begin{array}{r}-3.31^{* * *} \\
{[0.89]}\end{array}$ & $\begin{array}{r}-13.93^{* * *} \\
{[2.25]}\end{array}$ & $\begin{array}{c}1.05^{* *} \\
{[0.44]}\end{array}$ & $\begin{array}{l}1.91^{*} \\
{[0.98]}\end{array}$ & $\begin{array}{r}-1.70^{* * *} \\
{[0.57]}\end{array}$ & $\begin{array}{r}-3.32^{* * *} \\
{[0.95]}\end{array}$ \\
\hline$Q_{4}$ & $\begin{array}{r}0.33 \\
{[1.43]}\end{array}$ & $\begin{array}{l}-1.32 \\
{[0.91]}\end{array}$ & $\begin{array}{r}0.35 \\
{[0.90]}\end{array}$ & $\begin{array}{r}-3.78^{* * *} \\
{[1.27]}\end{array}$ & $\begin{array}{r}3.83^{* * *} \\
{[0.46]}\end{array}$ & $\begin{array}{r}2.64^{* *} \\
{[1.04]}\end{array}$ & $\begin{array}{r}-1.91^{* * *} \\
{[0.48]}\end{array}$ & $\begin{array}{r}-3.34^{* * *} \\
{[1.14]}\end{array}$ & $\begin{array}{r}-4.58^{* * *} \\
{[0.70]}\end{array}$ & $\begin{array}{l}-1.25 \\
{[0.89]}\end{array}$ \\
\hline vat $_{95}$ & $\begin{array}{r}4.28 \\
{[3.07]}\end{array}$ & $\begin{array}{r}5.79^{* *} \\
{[2.84]}\end{array}$ & $\begin{array}{l}-1.35 \\
{[2.15]}\end{array}$ & $\begin{array}{r}-9.72^{* *} \\
{[4.74]}\end{array}$ & $\begin{array}{r}4.86^{* *} \\
{[2.28]}\end{array}$ & $\begin{array}{l}-5.31 \\
{[5.14]}\end{array}$ & $\begin{array}{r}2.55^{* * *} \\
{[0.87]}\end{array}$ & $\begin{array}{l}-1.70 \\
{[4.06]}\end{array}$ & $\begin{array}{r}13.41^{* * *} \\
{[2.32]}\end{array}$ & $\begin{array}{l}4.51^{*} \\
{[2.35]}\end{array}$ \\
\hline vat $_{99}$ & $\begin{array}{r}1.77 \\
{[2.90]}\end{array}$ & $\begin{array}{r}2.48 \\
{[2.08]}\end{array}$ & $\begin{array}{r}1.03 \\
{[1.92]}\end{array}$ & $\begin{array}{l}-1.84 \\
{[3.91]}\end{array}$ & $\begin{array}{r}-42.29^{* * *} \\
{[3.27]}\end{array}$ & $\begin{array}{r}4.95^{* *} \\
{[2.22]}\end{array}$ & $\begin{array}{r}-2.77^{* *} \\
{[1.40]}\end{array}$ & $\begin{array}{r}0.03 \\
{[2.93]}\end{array}$ & $\begin{array}{r}-7.01^{* * *} \\
{[2.38]}\end{array}$ & $\begin{array}{r}1.35 \\
{[2.77]}\end{array}$ \\
\hline vat $_{01}$ & $\begin{array}{r}0.64 \\
{[3.91]}\end{array}$ & $\begin{array}{r}0.79 \\
{[2.96]}\end{array}$ & $\begin{array}{r}3.83^{* *} \\
{[1.62]} \\
\end{array}$ & $\begin{array}{l}-7.15 \\
{[4.85]}\end{array}$ & $\begin{array}{r}-47.16^{* * *} \\
{[3.33]}\end{array}$ & $\begin{array}{l}-0.18 \\
{[7.62]}\end{array}$ & $\begin{array}{r}3.71^{* * *} \\
{[0.93]}\end{array}$ & $\begin{array}{r}2.40 \\
{[1.98]}\end{array}$ & $\begin{array}{r}8.21^{* * *} \\
{[1.32]}\end{array}$ & $\begin{array}{r}0.07 \\
{[2.58]} \\
\end{array}$ \\
\hline $\begin{array}{l}\text { Avg. } \theta_{i t}^{+}-\mu_{i} \\
\text { Avg. } \theta_{i t}^{-}-\mu_{i}\end{array}$ & $\begin{array}{r}27.12 \\
-36.58\end{array}$ & $\begin{array}{r}23.89 \\
-33.92\end{array}$ & $\begin{array}{r}17.39 \\
-15.49\end{array}$ & $\begin{array}{r}22.18 \\
-34.66\end{array}$ & $\begin{array}{r}21.36 \\
-21.21\end{array}$ & $\begin{array}{r}28.33 \\
-39.90\end{array}$ & $\begin{array}{r}22.31 \\
-28.59\end{array}$ & $\begin{array}{r}34.39 \\
-35.43\end{array}$ & $\begin{array}{r}14.93 \\
-25.98\end{array}$ & $\begin{array}{r}28.90 \\
-34.93\end{array}$ \\
\hline Fit (positive) & 0.89 & 0.86 & 0.74 & 0.86 & 0.97 & 0.94 & 0.85 & 0.84 & 0.90 & 0.85 \\
\hline Fit (negative) & 0.54 & 0.49 & 0.59 & 0.68 & 0.85 & 0.85 & 0.48 & 0.61 & 0.72 & 0.63 \\
\hline Estim. range & 12 & 12 & 12 & 12 & 12 & 12 & 12 & 12 & 12 & 12 \\
\hline Observations & 23540 & 49982 & 6511 & 14409 & 12585 & 11181 & 110362 & 32588 & 28978 & 24727 \\
\hline
\end{tabular}

Note: See Table 3. 
Table 12: Estimates sector level (contd.)

\begin{tabular}{|c|c|c|c|c|c|c|c|c|c|c|}
\hline & E010 & E011 & E012 & F002 & F003 & G001 & G002 & G003 & G004 & G006 \\
\hline$\sum_{i t}^{*} \bar{\pi}_{j t}$ & $\begin{array}{r}1.46^{* * *} \\
{[0.13]}\end{array}$ & $\begin{array}{r}0.80^{* * *} \\
{[0.19]}\end{array}$ & $\begin{array}{r}1.74^{* * *} \\
{[0.13]}\end{array}$ & $\begin{array}{r}2.02^{* * *} \\
{[0.76]}\end{array}$ & $\begin{array}{r}1.19^{* * *} \\
{[0.13]}\end{array}$ & $\begin{array}{r}1.02^{* * *} \\
{[0.17]}\end{array}$ & $\begin{array}{r}1.31^{* * *} \\
{[0.16]}\end{array}$ & $\begin{array}{r}2.07^{* * *} \\
{[0.25]}\end{array}$ & $\begin{array}{r}1.20^{* * *} \\
{[0.09]}\end{array}$ & $\begin{array}{r}0.76^{* * *} \\
{[0.13]}\end{array}$ \\
\hline$\sum \hat{\pi}_{j t}^{+}$ & $\begin{array}{r}1.62^{* * *} \\
{[0.46]}\end{array}$ & $\begin{array}{r}0.98 \\
{[0.89]}\end{array}$ & $\begin{array}{r}2.89^{* * *} \\
{[0.33]}\end{array}$ & $\begin{array}{r}5.16^{* * *} \\
{[1.28]}\end{array}$ & $\begin{array}{r}3.58^{* * *} \\
{[0.94]}\end{array}$ & $\begin{array}{r}2.74^{* * *} \\
{[0.45]}\end{array}$ & $\begin{array}{r}1.72^{* * *} \\
{[0.38]}\end{array}$ & $\begin{array}{r}1.88^{* * *} \\
{[0.29]}\end{array}$ & $\begin{array}{r}0.33 \\
{[0.51]}\end{array}$ & $\begin{array}{r}3.15^{* * *} \\
{[0.39]}\end{array}$ \\
\hline$\sum \hat{\pi}_{j t}^{-}$ & $\begin{array}{r}-0.44 \\
{[0.49]}\end{array}$ & $\begin{array}{r}-2.82^{* * *} \\
{[0.97]} \\
\end{array}$ & $\begin{array}{r}-0.19 \\
{[0.35]}\end{array}$ & $\begin{array}{r}1.02 \\
{[1.15]}\end{array}$ & $\begin{array}{r}-2.55^{* * *} \\
{[0.96]}\end{array}$ & $\begin{array}{r}-0.26 \\
{[0.26]}\end{array}$ & $\begin{array}{r}0.45 \\
{[0.30]}\end{array}$ & $\begin{array}{r}0.33 \\
{[0.27]} \\
\end{array}$ & $\begin{array}{r}1.21^{* * *} \\
{[0.44]}\end{array}$ & $\begin{array}{r}3.48^{* * *} \\
{[0.59]}\end{array}$ \\
\hline$\sigma_{\varepsilon}$ & $\begin{array}{r}10.47^{* * *} \\
{[0.47]}\end{array}$ & $\begin{array}{r}13.63^{* * *} \\
{[0.77]}\end{array}$ & $\begin{array}{r}14.06^{* * *} \\
{[0.44]}\end{array}$ & $\begin{array}{r}14.28^{* * *} \\
{[1.13]}\end{array}$ & $\begin{array}{r}11.03^{* * *} \\
{[2.23]}\end{array}$ & $\begin{array}{r}4.12^{* * *} \\
{[0.39]}\end{array}$ & $\begin{array}{r}12.18^{* * *} \\
{[0.53]}\end{array}$ & $\begin{array}{r}21.76^{* * *} \\
{[0.79]}\end{array}$ & $\begin{array}{r}16.44^{* * *} \\
{[0.50]}\end{array}$ & $\begin{array}{r}9.93^{* * *} \\
{[0.59]}\end{array}$ \\
\hline $\begin{array}{l}\theta_{i t}^{+} \\
\bar{\pi}_{j t}\end{array}$ & $\begin{array}{r}1.30 \\
{[1.00]}\end{array}$ & $\begin{array}{r}0.96 \\
{[2.29]}\end{array}$ & $\begin{array}{r}-4.91^{* * *} \\
{[0.87]}\end{array}$ & $\begin{array}{l}-1.53 \\
{[2.99]}\end{array}$ & $\begin{array}{r}-12.31^{* * *} \\
{[4.43]}\end{array}$ & $\begin{array}{r}-5.01^{* * *} \\
{[1.04]}\end{array}$ & $\begin{array}{r}-12.33^{* * *} \\
{[1.03]}\end{array}$ & $\begin{array}{r}1.85 \\
{[1.19]}\end{array}$ & $\begin{array}{r}-5.98^{* * *} \\
{[0.68]}\end{array}$ & $\begin{array}{r}-3.95^{* * *} \\
{[1.45]}\end{array}$ \\
\hline$Q_{2}$ & $\begin{array}{l}-0.40 \\
{[0.29]}\end{array}$ & $\begin{array}{l}-0.42 \\
{[0.48]}\end{array}$ & $\begin{array}{r}0.23 \\
{[0.32]}\end{array}$ & $\begin{array}{r}-9.10^{* * *} \\
{[1.42]}\end{array}$ & $\begin{array}{r}1.13^{* *} \\
{[0.50]}\end{array}$ & $\begin{array}{r}0.84^{* * *} \\
{[0.23]}\end{array}$ & $\begin{array}{c}0.84^{* *} \\
{[0.41]}\end{array}$ & $\begin{array}{r}-4.64^{* * *} \\
{[0.55]}\end{array}$ & $\begin{array}{r}-5.99^{* * *} \\
{[0.67]}\end{array}$ & $\begin{array}{l}1.18^{*} \\
{[0.69]}\end{array}$ \\
\hline$Q_{3}$ & $\begin{array}{r}2.84^{* * *} \\
{[0.38]}\end{array}$ & $\begin{array}{r}1.30^{* *} \\
{[0.51]}\end{array}$ & $\begin{array}{r}0.75^{* *} \\
{[0.32]}\end{array}$ & $\begin{array}{r}-5.63^{* * *} \\
{[1.28]}\end{array}$ & $\begin{array}{r}8.93^{* * *} \\
{[2.06]}\end{array}$ & $\begin{array}{r}0.65^{* * *} \\
{[0.20]}\end{array}$ & $\begin{array}{r}11.47^{* * *} \\
{[0.69]}\end{array}$ & $\begin{array}{l}1.02^{*} \\
{[0.53]}\end{array}$ & $\begin{array}{r}0.04 \\
{[0.67]}\end{array}$ & $\begin{array}{r}6.70^{* * * *} \\
{[0.85]}\end{array}$ \\
\hline$Q_{4}$ & $\begin{array}{r}4.05^{* * *} \\
{[0.42]}\end{array}$ & $\begin{array}{r}2.19^{* * *} \\
{[0.54]}\end{array}$ & $\begin{array}{r}1.89^{* * *} \\
{[0.34]}\end{array}$ & $\begin{array}{l}-1.26 \\
{[1.37]}\end{array}$ & $\begin{array}{r}6.38^{* * *} \\
\quad[1.48]\end{array}$ & $\begin{array}{r}1.41^{* * *} \\
{[0.26]}\end{array}$ & $\begin{array}{r}7.67^{* * *} \\
{[0.60]}\end{array}$ & $\begin{array}{r}2.33^{* * *} \\
{[0.52]}\end{array}$ & $\begin{array}{r}-5.69^{* * *} \\
{[0.66]}\end{array}$ & $\begin{array}{r}6.38^{* * *} \\
{[0.95]}\end{array}$ \\
\hline vat $_{95}$ & $\begin{array}{r}-3.62^{* * *} \\
{[0.53]}\end{array}$ & $\begin{array}{r}-3.04^{* *} \\
{[1.20]}\end{array}$ & $\begin{array}{r}-8.07^{* * *} \\
{[0.69]}\end{array}$ & $\begin{array}{r}-8.96^{* * *} \\
{[2.92]}\end{array}$ & $\begin{array}{l}-1.01 \\
{[0.98]}\end{array}$ & $\begin{array}{r}-4.08^{* * *} \\
{[0.72]}\end{array}$ & $\begin{array}{r}-7.24^{* * *} \\
{[1.17]}\end{array}$ & $\begin{array}{r}-28.68^{* * *} \\
{[1.94]}\end{array}$ & $\begin{array}{r}5.55^{* * *} \\
{[1.95]}\end{array}$ & $\begin{array}{r}1.64 \\
{[2.31]}\end{array}$ \\
\hline vat $_{99}$ & $\begin{array}{r}-2.64^{* * *} \\
{[0.66]}\end{array}$ & $\begin{array}{r}-6.71^{* * *} \\
{[1.18]}\end{array}$ & $\begin{array}{r}-9.88^{* * *} \\
{[0.61]}\end{array}$ & $\begin{array}{r}-18.70^{* * *} \\
{[2.55]}\end{array}$ & $\begin{array}{l}-0.87 \\
{[1.05]}\end{array}$ & $\begin{array}{r}-6.69^{* * *} \\
{[0.82]}\end{array}$ & $\begin{array}{r}-6.97^{* * *} \\
{[0.88]}\end{array}$ & $\begin{array}{r}-28.07^{* * *} \\
{[1.48]}\end{array}$ & $\begin{array}{r}-9.35^{* * *} \\
{[1.36]}\end{array}$ & $\begin{array}{r}-2.83^{*} \\
{[1.56]}\end{array}$ \\
\hline vat $_{01}$ & $\begin{array}{r}-5.20^{* * *} \\
{[0.70]}\end{array}$ & $\begin{array}{r}-6.02^{* * *} \\
{[1.09]}\end{array}$ & $\begin{array}{r}-3.68^{* * *} \\
{[0.76]} \\
\end{array}$ & $\begin{array}{r}-8.30^{* * *} \\
{[2.39]} \\
\end{array}$ & $\begin{array}{r}-2.91^{* * *} \\
{[0.93]} \\
\end{array}$ & $\begin{array}{r}-4.35^{* * *} \\
{[0.65]}\end{array}$ & $\begin{array}{r}-1.50^{*} \\
{[0.82]}\end{array}$ & $\begin{array}{r}-19.88^{* * *} \\
{[1.45]}\end{array}$ & $\begin{array}{r}-17.37^{* * *} \\
{[1.41]}\end{array}$ & $\begin{array}{r}-4.41^{* * *} \\
{[1.38]}\end{array}$ \\
\hline $\begin{array}{l}\theta_{i t}^{-} \\
\bar{\pi}_{j t}\end{array}$ & $\begin{array}{l}-3.04 \\
{[1.92]}\end{array}$ & $\begin{array}{r}6.53^{* *} \\
{[3.06]}\end{array}$ & $\begin{array}{l}-0.53 \\
{[1.19]}\end{array}$ & $\begin{array}{r}-9.72^{* *} \\
{[4.19]}\end{array}$ & $\begin{array}{r}29.52^{* * *} \\
{[10.58]}\end{array}$ & $\begin{array}{r}-4.31^{* *} \\
{[1.81]}\end{array}$ & $\begin{array}{r}-3.04^{* * *} \\
{[1.16]}\end{array}$ & $\begin{array}{r}-5.85^{* * *} \\
{[1.34]}\end{array}$ & $\begin{array}{r}-3.00^{* * *} \\
{[0.67]}\end{array}$ & $\begin{array}{r}6.29^{* * *} \\
{[2.12]}\end{array}$ \\
\hline$Q_{2}$ & $\begin{array}{c}-0.81 \\
{[0.58]}\end{array}$ & $\begin{array}{l}-0.39 \\
{[0.71]}\end{array}$ & $\begin{array}{l}-0.03 \\
{[0.40]}\end{array}$ & $\begin{array}{r}5.01^{* * *} \\
{[1.33]}\end{array}$ & $\begin{array}{r}14.73^{* * *} \\
{[3.65]}\end{array}$ & $\begin{array}{r}0.08 \\
{[0.31]}\end{array}$ & $\begin{array}{r}-2.92^{* * *} \\
{[0.44]}\end{array}$ & $\begin{array}{r}6.94^{* * *} \\
{[0.67]}\end{array}$ & $\begin{array}{r}9.85^{* * *} \\
{[0.75]}\end{array}$ & $\begin{array}{r}1.10 \\
{[0.85]}\end{array}$ \\
\hline$Q_{3}$ & $\begin{array}{r}-1.66^{* * *} \\
{[0.59]}\end{array}$ & $\begin{array}{l}-0.79 \\
{[0.70]}\end{array}$ & $\begin{array}{r}-0.07 \\
{[0.42]}\end{array}$ & $\begin{array}{r}2.69^{* *} \\
{[1.32]}\end{array}$ & $\begin{array}{r}9.52^{* * *} \\
{[2.82]}\end{array}$ & $\begin{array}{r}-0.84^{* *} \\
{[0.35]}\end{array}$ & $\begin{array}{r}-12.99^{* * *} \\
{[0.86]}\end{array}$ & $\begin{array}{l}-0.87 \\
{[0.68]}\end{array}$ & $\begin{array}{r}0.05 \\
{[0.73]}\end{array}$ & $\begin{array}{r}-7.19^{* * *} \\
{[1.43]}\end{array}$ \\
\hline$Q_{4}$ & $\begin{array}{r}-3.20^{* * *} \\
{[0.64]}\end{array}$ & $\begin{array}{r}-2.50^{* * *} \\
{[0.76]}\end{array}$ & $\begin{array}{r}-1.03^{* *} \\
{[0.44]}\end{array}$ & $\begin{array}{r}-2.80^{*} \\
{[1.54]}\end{array}$ & $\begin{array}{r}11.98^{* * *} \\
{[3.11]}\end{array}$ & $\begin{array}{r}-0.89^{* * *} \\
{[0.33]}\end{array}$ & $\begin{array}{r}-9.12^{* * *} \\
{[0.67]}\end{array}$ & $\begin{array}{r}2.84^{* * *} \\
{[0.68]}\end{array}$ & $\begin{array}{r}8.46^{* * *} \\
{[0.67]}\end{array}$ & $\begin{array}{r}0.69 \\
{[0.83]}\end{array}$ \\
\hline vat $_{95}$ & $\begin{array}{r}0.82 \\
{[1.19]}\end{array}$ & $\begin{array}{r}1.53 \\
{[1.60]}\end{array}$ & $\begin{array}{r}2.42^{* *} \\
{[0.94]}\end{array}$ & $\begin{array}{r}-14.80^{*} \\
{[7.89]}\end{array}$ & $\begin{array}{r}14.77^{* * *} \\
{[4.49]}\end{array}$ & $\begin{array}{r}1.91^{* *} \\
{[0.75]}\end{array}$ & $\begin{array}{r}-4.93^{* * *} \\
{[1.39]}\end{array}$ & $\begin{array}{r}6.64^{* * *} \\
{[2.18]}\end{array}$ & $\begin{array}{r}5.36^{* *} \\
{[2.34]}\end{array}$ & $\begin{array}{r}-22.38^{* * *} \\
{[5.89]}\end{array}$ \\
\hline vat $_{99}$ & $\begin{array}{l}-2.96 \\
{[1.84]}\end{array}$ & $\begin{array}{l}-0.49 \\
{[2.36]}\end{array}$ & $\begin{array}{r}2.53^{* *} \\
{[1.12]}\end{array}$ & $\begin{array}{r}0.57 \\
{[3.16]}\end{array}$ & $\begin{array}{r}27.29^{* * *} \\
{[6.09]}\end{array}$ & $\begin{array}{r}0.36 \\
{[0.69]}\end{array}$ & $\begin{array}{r}-4.34^{* * *} \\
{[1.36]}\end{array}$ & $\begin{array}{r}12.00^{* * *} \\
{[1.48]}\end{array}$ & $\begin{array}{r}-3.69^{*} \\
{[2.10]}\end{array}$ & $\begin{array}{r}16.19^{* * *} \\
{[1.89]}\end{array}$ \\
\hline$v_{a t}$ & $\begin{array}{r}-0.79 \\
{[1.62]}\end{array}$ & $\begin{array}{l}-3.35 \\
{[2.38]}\end{array}$ & $\begin{array}{r}1.32 \\
{[1.47]}\end{array}$ & $\begin{array}{r}4.69 \\
{[3.65]} \\
\end{array}$ & $\begin{array}{r}7.20 \\
{[4.93]} \\
\end{array}$ & $\begin{array}{l}-0.09 \\
{[1.10]}\end{array}$ & $\begin{array}{r}-2.73^{*} \\
{[1.41]}\end{array}$ & $\begin{array}{r}10.96^{* * *} \\
{[1.63]}\end{array}$ & $\begin{array}{l}-1.31 \\
{[1.78]}\end{array}$ & $\begin{array}{r}11.61^{* * *} \\
{[2.26]}\end{array}$ \\
\hline $\begin{array}{l}\text { Avg. } \theta_{i t}^{+}-\mu_{i} \\
\text { Avg. } \theta_{i t}^{-}-\mu_{i}\end{array}$ & $\begin{array}{r}20.39 \\
-27.45 \\
\end{array}$ & $\begin{array}{r}27.52 \\
-30.38\end{array}$ & $\begin{array}{r}28.88 \\
-28.21\end{array}$ & $\begin{array}{r}32.59 \\
-28.22\end{array}$ & $\begin{array}{r}33.87 \\
-29.18\end{array}$ & $\begin{array}{r}6.48 \\
-6.71\end{array}$ & $\begin{array}{r}22.79 \\
-29.49\end{array}$ & $\begin{array}{r}26.43 \\
-33.62\end{array}$ & $\begin{array}{r}20.69 \\
-18.70\end{array}$ & $\begin{array}{r}12.79 \\
-27.51\end{array}$ \\
\hline Fit (positive) & 0.83 & 0.81 & 0.79 & 0.81 & 0.80 & 0.81 & 0.84 & 0.78 & 0.71 & 0.79 \\
\hline Fit (negative) & 0.49 & 0.49 & 0.45 & 0.67 & 0.56 & 0.55 & 0.72 & 0.58 & 0.66 & 0.63 \\
\hline Estim. range & 12 & 12 & 12 & 12 & 16 & 12 & 12 & 12 & 12 & 12 \\
\hline Observations & 54359 & 37311 & 108521 & 12091 & 28954 & 11242 & 46092 & 59703 & 25988 & 6650 \\
\hline
\end{tabular}


Table 13: Estimates sector level (contd.)

\begin{tabular}{|c|c|c|c|c|c|c|c|c|c|c|}
\hline & G007 & G008 & I001 & I002 & I003 & $\mathrm{I} 004$ & I005 & I006 & I007 & I008 \\
\hline$\sum_{i t}^{*} \bar{\pi}_{j t}$ & $\begin{array}{r}2.08^{* * *} \\
{[0.41]}\end{array}$ & $\begin{array}{r}0.89^{* * *} \\
{[0.07]}\end{array}$ & $\begin{array}{r}0.93^{* * *} \\
{[0.08]}\end{array}$ & $\begin{array}{r}0.79^{* * *} \\
{[0.08]}\end{array}$ & $\begin{array}{r}0.63^{* * *} \\
{[0.04]}\end{array}$ & $\begin{array}{r}0.34^{* * *} \\
{[0.11]}\end{array}$ & $\begin{array}{r}0.24 \\
{[0.45]}\end{array}$ & $\begin{array}{r}-1.79^{* * *} \\
{[0.39]}\end{array}$ & $\begin{array}{r}1.02^{* * *} \\
{[0.18]}\end{array}$ & $\begin{array}{r}3.07^{* * *} \\
{[0.69]}\end{array}$ \\
\hline$\sum \hat{\pi}_{j t}^{+}$ & $\begin{array}{r}-3.09^{* * *} \\
{[1.04]}\end{array}$ & $\begin{array}{r}1.51^{* * *} \\
{[0.28]}\end{array}$ & $\begin{array}{r}0.05 \\
{[0.47]}\end{array}$ & $\begin{array}{r}1.60^{* * *} \\
{[0.36]}\end{array}$ & $\begin{array}{r}0.50^{* *} \\
{[0.22]}\end{array}$ & $\begin{array}{l}-0.03 \\
{[0.39]}\end{array}$ & $\begin{array}{r}1.22^{* * *} \\
{[0.37]}\end{array}$ & $\begin{array}{r}4.54^{* * *} \\
\quad[1.14]\end{array}$ & $\begin{array}{r}0.19 \\
{[1.34]}\end{array}$ & $\begin{array}{r}3.33^{* *} \\
{[1.39]}\end{array}$ \\
\hline$\sum \hat{\pi}_{j t}^{-}$ & $\begin{array}{r}4.50^{* * *} \\
{[1.48]}\end{array}$ & $\begin{array}{r}-0.04 \\
{[0.21]}\end{array}$ & $\begin{array}{r}0.56 \\
{[0.49]} \\
\end{array}$ & $\begin{array}{r}0.63 \\
{[0.43]} \\
\end{array}$ & $\begin{array}{r}-0.88^{* * *} \\
{[0.33]} \\
\end{array}$ & $\begin{array}{l}0.79^{*} \\
{[0.41]}\end{array}$ & $\begin{array}{r}0.75 \\
{[0.50]}\end{array}$ & $\begin{array}{l}-1.00 \\
{[1.21]}\end{array}$ & $\begin{array}{r}0.10 \\
{[0.97]} \\
\end{array}$ & $\begin{array}{r}-1.90^{*} \\
{[1.04]} \\
\end{array}$ \\
\hline$\sigma_{\varepsilon}$ & $\begin{array}{r}9.17^{* *} \\
{[3.59]} \\
\end{array}$ & $\begin{array}{r}5.93^{* * *} \\
{[0.94]} \\
\end{array}$ & $\begin{array}{r}27.77^{* * *} \\
{[1.22]}\end{array}$ & $\begin{array}{r}37.16^{* * *} \\
{[1.88]}\end{array}$ & $\begin{array}{r}31.00^{* * *} \\
{[1.16]}\end{array}$ & $\begin{array}{r}22.33^{* * *} \\
{[1.60]}\end{array}$ & $\begin{array}{r}17.80^{* * *} \\
{[1.27]}\end{array}$ & $\begin{array}{r}13.47^{* * *} \\
{[0.47]}\end{array}$ & $\begin{array}{r}27.49^{* * *} \\
{[0.91]}\end{array}$ & $\begin{array}{r}11.91^{* * *} \\
{[1.01]}\end{array}$ \\
\hline $\begin{array}{l}\theta_{i t}^{+} \\
\bar{\pi}_{j t}\end{array}$ & $\begin{array}{l}-1.79 \\
{[8.35]}\end{array}$ & $\begin{array}{r}-2.47^{* * *} \\
{[0.58]}\end{array}$ & $\begin{array}{r}11.41^{* * *} \\
{[2.59]}\end{array}$ & $\begin{array}{l}-0.97 \\
{[1.32]}\end{array}$ & $\begin{array}{r}-4.89^{* * *} \\
{[0.76]}\end{array}$ & $\begin{array}{r}4.72 \\
{[4.76]}\end{array}$ & $\begin{array}{r}-0.97 \\
{[2.31]}\end{array}$ & $\begin{array}{r}0.76 \\
{[2.28]}\end{array}$ & $\begin{array}{r}-5.60^{* *} \\
{[2.71]}\end{array}$ & $\begin{array}{r}-6.59^{*} \\
{[3.81]}\end{array}$ \\
\hline$Q_{2}$ & $\begin{array}{r}3.56 \\
{[3.07]}\end{array}$ & $\begin{array}{r}2.84^{* * *} \\
{[0.61]}\end{array}$ & $\begin{array}{r}8.11^{* * *} \\
{[0.96]}\end{array}$ & $\begin{array}{l}3.33^{*} \\
{[1.72]}\end{array}$ & $\begin{array}{r}10.38^{* * *} \\
{[1.03]}\end{array}$ & $\begin{array}{l}-1.05 \\
{[1.01]}\end{array}$ & $\begin{array}{r}-0.52 \\
{[0.87]}\end{array}$ & $\begin{array}{r}-1.49^{* * *} \\
{[0.57]}\end{array}$ & $\begin{array}{r}4.80^{* * *} \\
{[0.85]}\end{array}$ & $\begin{array}{r}0.34 \\
{[0.72]}\end{array}$ \\
\hline$Q_{3}$ & $\begin{array}{r}2.57 \\
{[2.61]}\end{array}$ & $\begin{array}{r}4.50^{* * *} \\
{[0.89]}\end{array}$ & $\begin{array}{r}11.05^{* * *} \\
{[1.09]}\end{array}$ & $\begin{array}{r}5.49^{* * *} \\
{[1.65]}\end{array}$ & $\begin{array}{r}8.01^{* * *} \\
{[0.97]}\end{array}$ & $\begin{array}{r}-2.58^{* * *} \\
{[1.00]}\end{array}$ & $\begin{array}{r}3.51^{* * *} \\
{[0.92]}\end{array}$ & $\begin{array}{c}1.37^{* *} \\
{[0.59]}\end{array}$ & $\begin{array}{r}8.54^{* * *} \\
{[0.91]}\end{array}$ & $\begin{array}{r}0.88 \\
{[0.76]}\end{array}$ \\
\hline$Q_{4}$ & $\begin{array}{l}5.78^{*} \\
{[2.99]}\end{array}$ & $\begin{array}{r}2.41^{* * *} \\
{[0.66]}\end{array}$ & $\begin{array}{r}12.80^{* * *} \\
{[1.06]}\end{array}$ & $\begin{array}{r}3.51^{* *} \\
{[1.63]}\end{array}$ & $\begin{array}{r}2.43^{* * *} \\
{[0.94]}\end{array}$ & $\begin{array}{r}0.04 \\
{[1.00]}\end{array}$ & $\begin{array}{r}1.46 \\
{[0.89]}\end{array}$ & $\begin{array}{r}-7.54^{* * *} \\
{[0.56]}\end{array}$ & $\begin{array}{r}2.63^{* * *} \\
{[0.80]}\end{array}$ & $\begin{array}{r}2.15^{* * *} \\
{[0.78]}\end{array}$ \\
\hline vat $_{95}$ & $\begin{array}{l}-3.64 \\
{[4.77]}\end{array}$ & $\begin{array}{r}-3.77^{*} \\
{[2.27]}\end{array}$ & $\begin{array}{r}29.32^{* * *} \\
{[6.53]}\end{array}$ & $\begin{array}{r}15.13^{*} \\
{[9.09]}\end{array}$ & $\begin{array}{r}-14.20^{* * *} \\
{[4.12]}\end{array}$ & $\begin{array}{r}-4.68^{* *} \\
{[2.30]}\end{array}$ & $\begin{array}{l}-1.42 \\
{[2.82]}\end{array}$ & $\begin{array}{r}0.54 \\
{[1.53]}\end{array}$ & $\begin{array}{r}-9.48^{* * *} \\
{[2.04]}\end{array}$ & $\begin{array}{r}-8.47^{* * *} \\
{[2.59]}\end{array}$ \\
\hline vat $_{99}$ & $\begin{array}{r}-10.26^{* *} \\
{[4.20]}\end{array}$ & $\begin{array}{r}-8.59^{* * *} \\
{[2.52]}\end{array}$ & $\begin{array}{r}0.92 \\
{[2.57]}\end{array}$ & $\begin{array}{r}12.49^{* *} \\
{[5.83]}\end{array}$ & $\begin{array}{r}3.77 \\
{[4.21]}\end{array}$ & $\begin{array}{r}-5.83^{* * *} \\
{[2.05]}\end{array}$ & $\begin{array}{r}-5.52^{* * *} \\
{[1.74]}\end{array}$ & $\begin{array}{r}-2.97^{* *} \\
{[1.38]}\end{array}$ & $\begin{array}{l}-1.72 \\
{[1.85]}\end{array}$ & $\begin{array}{r}-6.43^{* * *} \\
{[1.45]}\end{array}$ \\
\hline vat $_{01}$ & $\begin{array}{r}-0.57 \\
{[3.69]} \\
\end{array}$ & $\begin{array}{r}6.16^{* * *} \\
{[2.05]}\end{array}$ & $\begin{array}{r}14.26^{* * *} \\
{[2.45]} \\
\end{array}$ & $\begin{array}{r}10.04^{* *} \\
{[4.31]}\end{array}$ & $\begin{array}{r}1.33 \\
{[3.08]} \\
\end{array}$ & $\begin{array}{r}-5.04^{* *} \\
{[2.13]}\end{array}$ & $\begin{array}{r}-2.75 \\
{[1.84]}\end{array}$ & $\begin{array}{r}1.02 \\
{[1.51]}\end{array}$ & $\begin{array}{r}0.84 \\
{[1.72]} \\
\end{array}$ & $\begin{array}{r}-3.75^{* *} \\
{[1.50]} \\
\end{array}$ \\
\hline $\begin{array}{l}\theta_{i t}^{-} \\
\bar{\pi}_{j t}\end{array}$ & $\begin{array}{r}14.85^{*} \\
{[7.70]}\end{array}$ & $\begin{array}{r}-5.65^{* *} \\
{[2.28]}\end{array}$ & $\begin{array}{r}-8.91^{* * *} \\
{[2.64]}\end{array}$ & $\begin{array}{r}-3.43^{* * *} \\
{[1.14]}\end{array}$ & $\begin{array}{r}-3.18^{* * *} \\
{[0.62]}\end{array}$ & $\begin{array}{r}1.17 \\
{[5.01]}\end{array}$ & $\begin{array}{r}-3.40 \\
{[3.05]}\end{array}$ & $\begin{array}{l}-1.25 \\
{[2.61]}\end{array}$ & $\begin{array}{r}0.81 \\
{[3.15]}\end{array}$ & $\begin{array}{r}-13.21^{* * *} \\
{[4.73]}\end{array}$ \\
\hline$Q_{2}$ & $\begin{array}{r}1.57 \\
{[4.77]}\end{array}$ & $\begin{array}{r}-3.32^{*} \\
{[1.85]}\end{array}$ & $\begin{array}{r}9.05^{* * *} \\
{[0.99]}\end{array}$ & $\begin{array}{r}3.93^{* * *} \\
{[1.27]}\end{array}$ & $\begin{array}{r}-2.78^{* * *} \\
{[0.73]}\end{array}$ & $\begin{array}{r}1.12 \\
{[0.95]}\end{array}$ & $\begin{array}{r}1.42 \\
{[1.11]}\end{array}$ & $\begin{array}{c}1.40^{* *} \\
{[0.61]}\end{array}$ & $\begin{array}{r}6.42^{* * *} \\
{[0.96]}\end{array}$ & $\begin{array}{r}2.69^{* * *} \\
{[0.99]}\end{array}$ \\
\hline$Q_{3}$ & $\begin{array}{r}1.30 \\
{[4.71]}\end{array}$ & $\begin{array}{r}-2.82^{*} \\
{[1.57]}\end{array}$ & $\begin{array}{r}4.28^{* * *} \\
{[0.93]}\end{array}$ & $\begin{array}{l}-0.83 \\
{[1.25]}\end{array}$ & $\begin{array}{r}-2.25^{* * *} \\
{[0.72]}\end{array}$ & $\begin{array}{r}0.24 \\
{[0.98]}\end{array}$ & $\begin{array}{l}-0.35 \\
{[1.14]}\end{array}$ & $\begin{array}{r}-1.46^{* *} \\
{[0.65]}\end{array}$ & $\begin{array}{r}4.60^{* * *} \\
{[0.97]}\end{array}$ & $\begin{array}{r}1.12 \\
{[1.04]}\end{array}$ \\
\hline$Q_{4}$ & $\begin{array}{r}5.01 \\
{[4.92]}\end{array}$ & $\begin{array}{l}-0.41 \\
{[1.76]}\end{array}$ & $\begin{array}{r}5.31^{* * *} \\
{[0.94]}\end{array}$ & $\begin{array}{r}3.78^{* * *} \\
\quad[1.29]\end{array}$ & $\begin{array}{r}-4.90^{* * *} \\
{[0.79]}\end{array}$ & $\begin{array}{l}1.70^{*} \\
{[0.92]}\end{array}$ & $\begin{array}{r}1.37 \\
{[1.09]}\end{array}$ & $\begin{array}{r}6.42^{* * *} \\
{[0.57]}\end{array}$ & $\begin{array}{r}-5.10^{* * *} \\
{[1.04]}\end{array}$ & $\begin{array}{r}1.41 \\
{[1.01]}\end{array}$ \\
\hline vat $_{95}$ & $\begin{array}{r}-88.64^{* * *} \\
{[31.68]}\end{array}$ & $\begin{array}{r}-51.06^{* * *} \\
{[7.19]}\end{array}$ & $\begin{array}{r}-7.81^{* *} \\
{[3.34]}\end{array}$ & $\begin{array}{l}-7.98 \\
{[5.33]}\end{array}$ & $\begin{array}{r}-11.85^{* * *} \\
{[3.19]}\end{array}$ & $\begin{array}{r}-9.39^{* * *} \\
{[3.54]}\end{array}$ & $\begin{array}{r}-6.46^{*} \\
{[3.85]}\end{array}$ & $\begin{array}{c}-3.04^{*} \\
{[1.78]}\end{array}$ & $\begin{array}{r}2.31 \\
{[2.58]}\end{array}$ & $\begin{array}{r}12.85^{* * *} \\
{[3.49]}\end{array}$ \\
\hline vat $_{99}$ & $\begin{array}{r}-79.72^{* * *} \\
{[30.20]}\end{array}$ & $\begin{array}{r}10.01^{* * *} \\
{[2.35]}\end{array}$ & $\begin{array}{r}6.78^{* * *} \\
{[2.11]}\end{array}$ & $\begin{array}{l}-7.54 \\
{[5.16]}\end{array}$ & $\begin{array}{r}7.66^{* * *} \\
{[2.80]}\end{array}$ & $\begin{array}{r}3.36 \\
{[2.26]}\end{array}$ & $\begin{array}{l}-0.89 \\
{[3.43]}\end{array}$ & $\begin{array}{r}1.63 \\
{[1.67]}\end{array}$ & $\begin{array}{r}0.30 \\
{[2.53]}\end{array}$ & $\begin{array}{r}4.86^{* *} \\
{[2.18]}\end{array}$ \\
\hline vat $_{01}$ & $\begin{array}{r}-67.18^{* *} \\
{[27.14]}\end{array}$ & $\begin{array}{r}-46.61^{* * *} \\
{[7.10]}\end{array}$ & $\begin{array}{r}-0.87 \\
{[2.47]}\end{array}$ & $\begin{array}{r}-5.43^{*} \\
{[3.23]}\end{array}$ & $\begin{array}{r}1.52 \\
{[2.57]}\end{array}$ & $\begin{array}{r}3.37 \\
{[2.39]}\end{array}$ & $\begin{array}{l}4.38^{*} \\
{[2.43]}\end{array}$ & $\begin{array}{l}-1.35 \\
{[1.60]}\end{array}$ & $\begin{array}{r}3.60 \\
{[2.27]} \\
\end{array}$ & $\begin{array}{r}1.91 \\
{[2.66]}\end{array}$ \\
\hline $\begin{array}{l}\text { Avg. } \theta_{i t}^{+}-\mu_{i} \\
\text { Avg. } \theta_{i t}^{-}-\mu_{i}\end{array}$ & $\begin{array}{r}22.65 \\
-41.50\end{array}$ & $\begin{array}{r}12.89 \\
-33.46\end{array}$ & $\begin{array}{r}42.38 \\
-49.54\end{array}$ & $\begin{array}{r}53.56 \\
-51.23\end{array}$ & $\begin{array}{r}35.97 \\
-28.30\end{array}$ & $\begin{array}{r}42.94 \\
-44.33\end{array}$ & $\begin{array}{r}32.86 \\
-37.87\end{array}$ & $\begin{array}{r}29.44 \\
-31.75\end{array}$ & $\begin{array}{r}47.15 \\
-50.27\end{array}$ & $\begin{array}{r}24.84 \\
-28.44\end{array}$ \\
\hline Fit (positive) & 0.88 & 0.89 & 0.82 & 0.77 & 0.75 & 0.88 & 0.84 & 0.81 & 0.78 & 0.86 \\
\hline Fit (negative) & 0.73 & 0.70 & 0.67 & 0.61 & 0.64 & 0.67 & 0.61 & 0.64 & 0.62 & 0.58 \\
\hline Estim. range & 12 & 16 & 12 & 12 & 12 & 12 & 12 & 12 & 12 & 12 \\
\hline Observations & 2575 & 6830 & 41271 & 23102 & 31604 & 40896 & 23171 & 59993 & 58166 & 19617 \\
\hline
\end{tabular}

Note: See Table 3. 
Table 14: Estimates sector level (contd.)

\begin{tabular}{|c|c|c|c|c|c|}
\hline & I009 & I010 & I011 & I012 & I013 \\
\hline$\sum_{i t}^{*} \bar{\pi}_{j t}$ & $\begin{array}{r}0.96^{* * *} \\
{[0.05]}\end{array}$ & $\begin{array}{r}1.19^{* * *} \\
{[0.13]}\end{array}$ & $\begin{array}{r}1.28^{* * *} \\
{[0.15]}\end{array}$ & $\begin{array}{r}1.59^{* * *} \\
{[0.13]}\end{array}$ & $\begin{array}{r}0.52 \\
{[0.66]}\end{array}$ \\
\hline$\sum \hat{\pi}_{j t}^{+}$ & $\begin{array}{r}0.34 \\
{[0.34]}\end{array}$ & $\begin{array}{r}0.93 \\
{[1.36]}\end{array}$ & $\begin{array}{r}2.66^{* * *} \\
{[0.84]}\end{array}$ & $\begin{array}{r}1.41^{* * *} \\
{[0.38]}\end{array}$ & $\begin{array}{l}-0.65 \\
{[0.40]}\end{array}$ \\
\hline$\sum \hat{\pi}_{j t}^{-}$ & $\begin{array}{r}2.04^{* * *} \\
{[0.40]}\end{array}$ & $\begin{array}{r}0.27 \\
{[1.10]}\end{array}$ & $\begin{array}{r}4.08^{* * *} \\
{[0.89]}\end{array}$ & $\begin{array}{r}3.53^{* * *} \\
{[0.82]}\end{array}$ & $\begin{array}{r}0.72 \\
{[0.64]}\end{array}$ \\
\hline$\sigma_{\varepsilon}$ & $\begin{array}{r}9.89^{* * *} \\
{[0.45]}\end{array}$ & $\begin{array}{r}8.90^{* * *} \\
{[1.81]}\end{array}$ & $\begin{array}{r}14.85^{* * *} \\
{[0.79]}\end{array}$ & $\begin{array}{r}5.90^{* * *} \\
{[0.84]}\end{array}$ & $\begin{array}{r}16.65^{* * *} \\
{[1.21]}\end{array}$ \\
\hline $\begin{array}{l}\theta_{i t}^{+} \\
\bar{\pi}_{j t}\end{array}$ & $\begin{array}{r}-6.07^{* * *} \\
{[0.59]}\end{array}$ & $\begin{array}{l}-1.48 \\
{[3.74]}\end{array}$ & $\begin{array}{r}-14.47^{* * *} \\
{[1.32]}\end{array}$ & $\begin{array}{r}0.73 \\
{[0.94]}\end{array}$ & $\begin{array}{r}-9.90^{* * *} \\
{[3.63]}\end{array}$ \\
\hline$Q_{2}$ & $\begin{array}{r}-1.38^{* *} \\
{[0.56]}\end{array}$ & $\begin{array}{r}9.74^{* * *} \\
{[1.99]}\end{array}$ & $\begin{array}{r}1.21^{* *} \\
{[0.51]}\end{array}$ & $\begin{array}{r}-2.65^{* * *} \\
{[0.79]}\end{array}$ & $\begin{array}{r}-0.49 \\
{[0.71]}\end{array}$ \\
\hline$Q_{3}$ & $\begin{array}{r}-10.20^{* * *} \\
{[0.70]}\end{array}$ & $\begin{array}{r}11.24^{* * *} \\
{[2.39]}\end{array}$ & $\begin{array}{r}3.93^{* * *} \\
{[0.58]}\end{array}$ & $\begin{array}{l}-0.26 \\
{[0.61]}\end{array}$ & $\begin{array}{r}1.70^{* *} \\
{[0.76]}\end{array}$ \\
\hline$Q_{4}$ & $\begin{array}{r}-4.76^{* * *} \\
{[0.58]}\end{array}$ & $\begin{array}{r}13.29^{* * *} \\
{[2.85]}\end{array}$ & $\begin{array}{r}4.59^{* * *} \\
{[0.59]}\end{array}$ & $\begin{array}{r}4.26^{* * *} \\
{[1.29]}\end{array}$ & $\begin{array}{r}1.14 \\
{[0.77]}\end{array}$ \\
\hline vat $_{95}$ & $\begin{array}{r}-1.98^{* *} \\
{[0.94]}\end{array}$ & $\begin{array}{r}-3.69^{*} \\
{[2.22]}\end{array}$ & $\begin{array}{r}6.46^{* * *} \\
{[1.32]}\end{array}$ & $\begin{array}{r}-10.88^{* * *} \\
{[2.96]}\end{array}$ & $\begin{array}{r}-3.66^{* *} \\
{[1.82]}\end{array}$ \\
\hline vat $_{99}$ & $\begin{array}{r}-0.90 \\
{[1.16]}\end{array}$ & $\begin{array}{r}-4.01^{* * *} \\
{[1.25]}\end{array}$ & $\begin{array}{r}-5.65^{* * *} \\
{[1.01]}\end{array}$ & $\begin{array}{r}-2.39^{* *} \\
{[1.14]}\end{array}$ & $\begin{array}{r}-3.55^{* *} \\
{[1.66]}\end{array}$ \\
\hline vat $_{01}$ & $\begin{array}{r}-3.18^{* * *} \\
{[0.88]} \\
\end{array}$ & $\begin{array}{r}-2.53^{* *} \\
{[1.21]} \\
\end{array}$ & $\begin{array}{r}4.33^{* * *} \\
{[1.06]} \\
\end{array}$ & $\begin{array}{r}1.50 \\
{[3.01]} \\
\end{array}$ & $\begin{array}{r}5.07^{* *} \\
{[2.11]}\end{array}$ \\
\hline $\begin{array}{l}\theta_{i t}^{-} \\
\bar{\pi}_{j t}\end{array}$ & $\begin{array}{r}-4.16^{* * *} \\
{[1.43]}\end{array}$ & $\begin{array}{r}-31.49^{* * *} \\
{[8.39]}\end{array}$ & $\begin{array}{r}-3.86^{* * *} \\
{[1.47]}\end{array}$ & $\begin{array}{r}4.04 \\
{[3.31]}\end{array}$ & $\begin{array}{r}-10.35^{* *} \\
{[4.74]}\end{array}$ \\
\hline$Q_{2}$ & $\begin{array}{r}3.10^{* * *} \\
{[0.91]}\end{array}$ & $\begin{array}{r}-8.33^{* * *} \\
{[3.03]}\end{array}$ & $\begin{array}{l}-0.49 \\
{[0.72]}\end{array}$ & $\begin{array}{r}2.54 \\
{[1.89]}\end{array}$ & $\begin{array}{r}-0.78 \\
{[1.05]}\end{array}$ \\
\hline$Q_{3}$ & $\begin{array}{r}9.75^{* * *} \\
{[0.91]}\end{array}$ & $\begin{array}{l}-1.64 \\
{[1.90]}\end{array}$ & $\begin{array}{l}-0.18 \\
{[0.70]}\end{array}$ & $\begin{array}{l}-3.29 \\
{[2.02]}\end{array}$ & $\begin{array}{r}-0.42 \\
{[1.05]}\end{array}$ \\
\hline$Q_{4}$ & $\begin{array}{r}2.40^{* * *} \\
{[0.92]}\end{array}$ & $\begin{array}{r}-11.59^{* * *} \\
{[3.72]}\end{array}$ & $\begin{array}{l}-1.12 \\
{[0.71]}\end{array}$ & $\begin{array}{c}-4.19^{*} \\
{[2.30]}\end{array}$ & $\begin{array}{r}1.61 \\
{[1.01]}\end{array}$ \\
\hline vat $_{95}$ & $\begin{array}{r}2.47 \\
{[1.95]}\end{array}$ & $\begin{array}{r}23.31^{* * *} \\
{[6.26]}\end{array}$ & $\begin{array}{r}-11.47^{* * *} \\
{[3.33]}\end{array}$ & $\begin{array}{r}-54.17^{* * *} \\
{[10.05]}\end{array}$ & $\begin{array}{r}4.31 \\
{[3.09]}\end{array}$ \\
\hline vat $_{99}$ & $\begin{array}{c}-9.72^{*} \\
{[5.14]}\end{array}$ & $\begin{array}{r}3.14 \\
{[2.85]}\end{array}$ & $\begin{array}{r}1.65 \\
{[1.71]}\end{array}$ & $\begin{array}{r}-46.89^{* * *} \\
{[6.69]}\end{array}$ & $\begin{array}{r}-3.91 \\
{[4.07]}\end{array}$ \\
\hline$v a t_{01}$ & $\begin{array}{r}6.23^{* * *} \\
{[1.79]}\end{array}$ & $\begin{array}{r}5.65 \\
{[4.05]}\end{array}$ & $\begin{array}{r}0.34 \\
{[1.95]}\end{array}$ & $\begin{array}{r}-49.44^{* * *} \\
{[6.89]}\end{array}$ & $\begin{array}{r}0.34 \\
{[3.03]}\end{array}$ \\
\hline $\begin{array}{l}\text { Avg. } \theta_{i t}^{+}-\mu_{i} \\
\text { Avg. } \theta_{i t}^{-}-\mu_{i}\end{array}$ & $\begin{array}{r}29.48 \\
-35.04\end{array}$ & $\begin{array}{r}24.32 \\
-27.39\end{array}$ & $\begin{array}{r}26.62 \\
-33.33\end{array}$ & $\begin{array}{r}28.72 \\
-25.89\end{array}$ & $\begin{array}{r}28.57 \\
-42.68\end{array}$ \\
\hline Fit (positive) & 0.85 & 0.88 & 0.83 & 0.83 & 0.89 \\
\hline Fit (negative) & 0.67 & 0.77 & 0.56 & 0.59 & 0.69 \\
\hline Estim. range & 12 & 12 & 12 & 12 & 12 \\
\hline Observations & 66900 & 10351 & 47004 & 7053 & 33244 \\
\hline
\end{tabular}

Note: See Table 3. 
A.2 Robustness tests 
Table 15: Estimates of desired price equation (full estimation range)

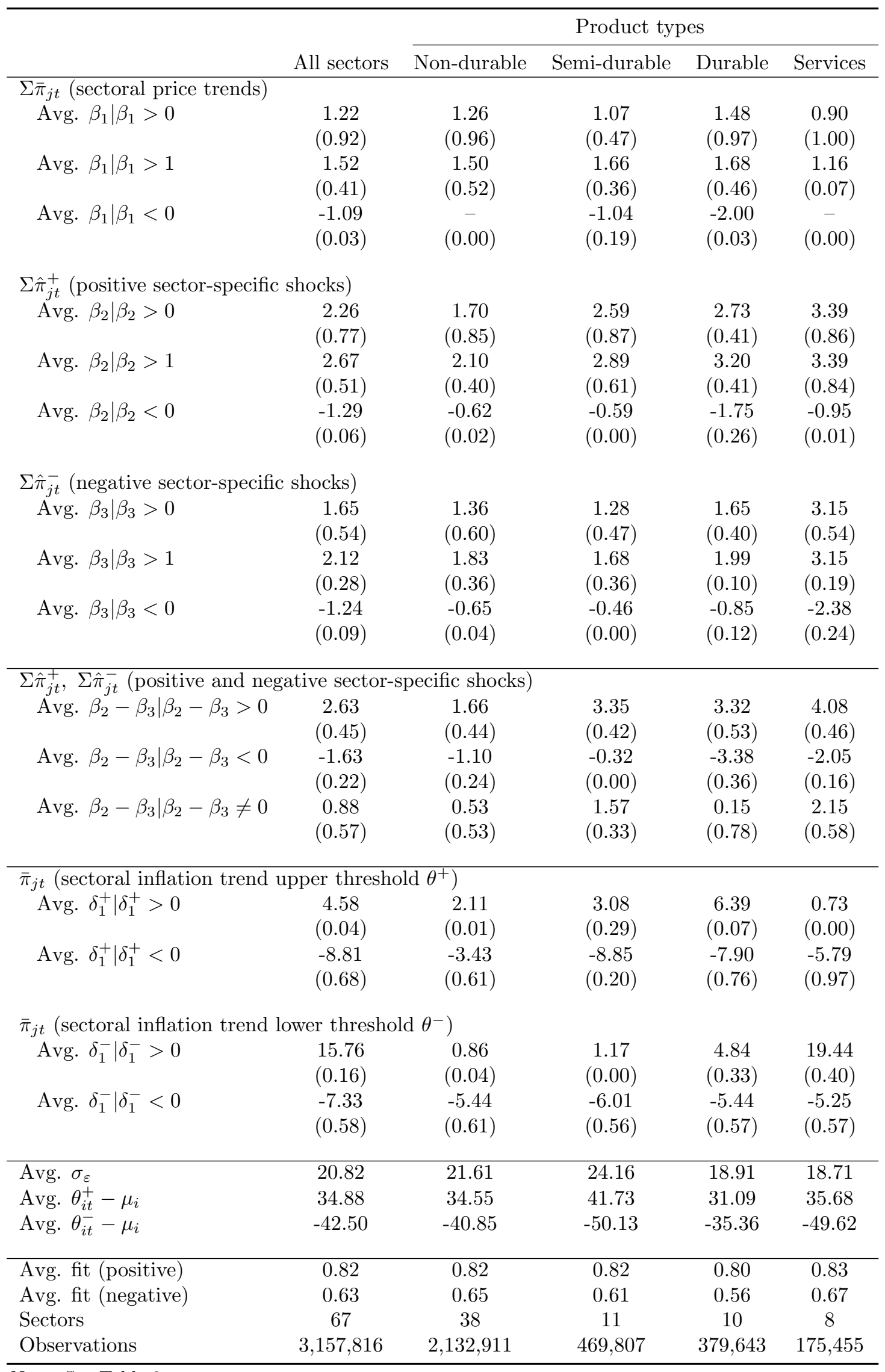

Note: See Table 3. 
Table 16: Estimates of desired price equation (aggregate price level and personal consumption)

\begin{tabular}{|c|c|c|c|c|c|}
\hline & \multirow[b]{2}{*}{ All sectors } & \multicolumn{4}{|c|}{ Product types } \\
\hline & & Non-durable & Semi-durable & Durable & Services \\
\hline \multicolumn{6}{|l|}{$\Sigma \bar{\pi}_{j t}$ (sectoral price trends) } \\
\hline \multirow[t]{2}{*}{ Avg. $\beta_{1} \mid \beta_{1}>0$} & 0.87 & 1.05 & 0.66 & 0.78 & 0.47 \\
\hline & $(0.68)$ & $(0.88)$ & $(0.49)$ & $(0.43)$ & $(0.47)$ \\
\hline \multirow[t]{2}{*}{ Avg. $\beta_{1} \mid \beta_{1}>1$} & 1.54 & 1.64 & 1.63 & 1.27 & 1.06 \\
\hline & $(0.13)$ & $(0.23)$ & $(0.09)$ & $(0.00)$ & $(0.00)$ \\
\hline Avg. $\beta_{1} \mid \beta_{1}<0$ & $\begin{array}{l}-0.41 \\
(0.04)\end{array}$ & $\begin{array}{l}-0.21 \\
(0.01)\end{array}$ & $\begin{array}{l}-0.99 \\
(0.25)\end{array}$ & $\begin{array}{l}-0.90 \\
(0.03)\end{array}$ & $\begin{array}{l}-0.14 \\
(0.00)\end{array}$ \\
\hline \multicolumn{6}{|c|}{$\Sigma \hat{\pi}_{j t}^{+}$(positive sector-specific shocks) } \\
\hline \multirow[t]{2}{*}{ Avg. $\beta_{2} \mid \beta_{2}>0$} & 1.51 & 1.07 & 1.72 & 1.83 & 2.69 \\
\hline & $(0.62)$ & $(0.63)$ & $(0.78)$ & $(0.49)$ & $(0.61)$ \\
\hline \multirow{2}{*}{ Avg. $\beta_{2} \mid \beta_{2}>1$} & 2.24 & 1.74 & 2.67 & 2.45 & 2.90 \\
\hline & $(0.32)$ & $(0.27)$ & $(0.32)$ & $(0.36)$ & $(0.39)$ \\
\hline Avg. $\beta_{2} \mid \beta_{2}<0$ & $\begin{array}{l}-0.59 \\
(0.06)\end{array}$ & $\begin{array}{l}-0.72 \\
(0.01)\end{array}$ & $\begin{array}{l}-0.26 \\
(0.02)\end{array}$ & $\begin{array}{l}-1.00 \\
(0.26)\end{array}$ & $\begin{array}{l}-0.16 \\
(0.01)\end{array}$ \\
\hline \multicolumn{6}{|c|}{$\Sigma \hat{\pi}_{j t}^{-}$(negative sector-specific shocks) } \\
\hline \multirow{2}{*}{ Avg. $\beta_{3} \mid \beta_{3}>0$} & 1.44 & 1.27 & 1.11 & 1.28 & 2.58 \\
\hline & $(0.59)$ & $(0.75)$ & $(0.56)$ & $(0.21)$ & $(0.54)$ \\
\hline Avg. $\beta_{3} \mid \beta_{3}>1$ & 1.90 & 1.66 & 1.40 & 2.21 & 2.70 \\
\hline & $(0.26)$ & $(0.30)$ & $(0.07)$ & $(0.10)$ & $(0.42)$ \\
\hline Avg. $\beta_{3} \mid \beta_{3}<0$ & -0.63 & -0.29 & -0.18 & -0.84 & -0.91 \\
\hline & $(0.06)$ & $(0.00)$ & $(0.00)$ & $(0.12)$ & $(0.22)$ \\
\hline$\Sigma \pi_{t}$ (aggregate price level) & & & & & \\
\hline Avg. $\beta_{4} \mid \beta_{4}>0$ & 0.97 & 0.81 & 0.86 & 1.33 & 1.28 \\
\hline & $(0.24)$ & $(0.23)$ & $(0.43)$ & $(0.14)$ & $(0.25)$ \\
\hline Avg. $\beta_{4} \mid \beta_{4}>1$ & 2.45 & 2.63 & 1.76 & 1.89 & 2.57 \\
\hline & $(0.09)$ & $(0.07)$ & $(0.07)$ & $(0.03)$ & $(0.22)$ \\
\hline Avg. $\beta_{4} \mid \beta_{4}<0$ & -0.65 & -1.01 & -0.73 & -0.28 & -0.03 \\
\hline & $(0.15)$ & $(0.23)$ & $(0.09)$ & $(0.10)$ & $(0.00)$ \\
\hline$\Sigma c_{t}$ (personal consumption ex & enditures) & & & & \\
\hline Avg. $\beta_{5} \mid \beta_{5}>0$ & 0.61 & 0.71 & 0.55 & 0.47 & 0.51 \\
\hline & $(0.65)$ & $(0.64)$ & $(0.56)$ & $(0.88)$ & $(0.52)$ \\
\hline Avg. $\beta_{5} \mid \beta_{5}>1$ & 1.54 & 1.55 & 1.31 & 0.00 & 1.66 \\
\hline & $(0.07)$ & $(0.13)$ & $(0.00)$ & $(0.00)$ & $(0.00)$ \\
\hline Avg. $\beta_{5} \mid \beta_{5}<0$ & -0.89 & -0.82 & -0.66 & -1.62 & -0.83 \\
\hline & $(0.17)$ & $(0.19)$ & $(0.07)$ & $(0.12)$ & $(0.22)$ \\
\hline$\overline{\Sigma \hat{\pi}_{j t}^{+}, \Sigma \hat{\pi}_{j t}^{-} \text {(positive and neg }}$ & tive sector-sI & cific shocks) & & & \\
\hline Avg. $\beta_{2}-\beta_{3} \mid \beta_{2}-\beta_{3}>0$ & 1.95 & 1.16 & 1.58 & 2.50 & 3.77 \\
\hline & $(0.33)$ & $(0.24)$ & $(0.26)$ & $(0.48)$ & $(0.46)$ \\
\hline Avg. $\beta_{2}-\beta_{3} \mid \beta_{2}-\beta_{3}<0$ & -1.32 & -1.04 & -0.74 & -1.95 & -1.78 \\
\hline Ayg $\beta_{0}-\beta_{0} \mid \beta_{0}-\beta_{2} \neq 0$ & $(0.30)$ & $(0.32)$ & $(0.02)$ & $(0.36)$ & $(0.36)$ \\
\hline Avg. $\beta_{2}-\beta_{3} \mid \beta_{2}-\beta_{3} \neq 0$ & $\begin{array}{l}0.28 \\
(0.60)\end{array}$ & $\begin{array}{l}-0.01 \\
(0.55)\end{array}$ & $\begin{array}{c}0.61 \\
(0.28)\end{array}$ & $\begin{array}{c}0.40 \\
(0.83)\end{array}$ & $\begin{array}{c}0.75 \\
(0.72)\end{array}$ \\
\hline $\bar{\pi}_{j t}$ (sectoral inflation trend $\mathrm{u}$ & per thresholc & $\left.\theta^{+}\right)$ & & & \\
\hline Avg. $\delta_{1}^{+} \mid \delta_{1}^{+}>0$ & 3.07 & 4.14 & 2.58 & 3.95 & 1.59 \\
\hline & $(0.07)$ & $(0.01)$ & $(0.45)$ & $(0.07)$ & $(0.03)$ \\
\hline Avg. $\delta_{1}^{+} \mid \delta_{1}^{+}<0$ & -4.62 & -3.49 & -8.01 & -7.15 & -4.91 \\
\hline & $(0.62)$ & $(0.65)$ & $(0.20)$ & $(0.41)$ & $(0.97)$ \\
\hline $\bar{\pi}_{j t}$ (sectoral inflation trend $\mathrm{l}$ & ver threshold & - ) & & & \\
\hline Avg. $\delta_{1}^{-} \mid \delta_{1}^{-}>0$ & 8.49 & 0.86 & 0.00 & 5.30 & 19.55 \\
\hline & $(0.16)$ & $(0.04)$ & $(0.00)$ & $(0.33)$ & $(0.40)$ \\
\hline Avg. $\delta_{1}^{-} \mid \delta_{1}^{-}<0$ & -5.53 & -5.48 & -6.84 & -5.03 & -4.95 \\
\hline & $(0.54)$ & $(0.62)$ & $(0.56)$ & $(0.27)$ & $(0.57)$ \\
\hline$\pi_{t}$ (aggregate inflation in the & pper thresho & $\left.\theta^{+}\right)$ & & & \\
\hline Avg. $\delta_{2}^{+} \mid \delta_{2}^{+}>0$ & 1.89 & 1.88 & 0.81 & 3.29 & 1.86 \\
\hline & $(0.11)$ & $(0.06)$ & $(0.00)$ & $(0.05)$ & $(0.37)$ \\
\hline Avg. $\delta_{2}^{+} \mid \delta_{2}^{+}<0$ & -2.64 & -2.56 & -3.60 & -3.08 & -1.67 \\
\hline & $(0.51)$ & $(0.64)$ & $(0.52)$ & $(0.33)$ & $(0.31)$ \\
\hline$\pi_{t}$ (aggregate inflation in the & ower threshol & $\left.\theta^{-}\right)$ & & & \\
\hline Avg. $\delta_{2}^{-} \mid \delta_{2}^{-}>0$ & 3.04 & 3.57 & 3.47 & 1.02 & 3.50 \\
\hline & $(0.34)$ & $(0.49)$ & $(0.52)$ & $(0.08)$ & $(0.07)$ \\
\hline Avg. $\delta_{2}^{-} \mid \delta_{2}^{-}<0$ & -3.16 & -2.83 & -0.76 & -2.56 & -3.83 \\
\hline & $(0.18)$ & $(0.15)$ & $(0.00)$ & $(0.30)$ & $(0.24)$ \\
\hline Avg. $\sigma_{\varepsilon}$ & 13.09 & 14.53 & 15.67 & 12.24 & 8.62 \\
\hline Avg. $\theta_{i t}^{+}-\mu_{i}$ & 26.04 & 27.45 & 31.64 & 22.03 & 23.06 \\
\hline Avg. $\theta_{i t}^{\frac{i t}{i t}}-\mu_{i}$ & -28.87 & -28.73 & -34.40 & -24.29 & -30.60 \\
\hline Avg. fit (positive) & 0.81 & 0.81 & 0.80 & 0.81 & 0.81 \\
\hline Avg. fit (negative) & 0.60 & 0.63 & 0.56 & 0.54 & 0.62 \\
\hline Sectors & 67 & 38 & 11 & 10 & 8 \\
\hline Observations & $3,157,816$ & $2,132,911$ & 469,807 & 379,643 & 175,455 \\
\hline
\end{tabular}

Note: See Table 3. 
Table 17: Estimates of desired price equation (HP filter for calculating the trend)

\begin{tabular}{|c|c|c|c|c|c|}
\hline & \multirow[b]{2}{*}{ All sectors } & \multicolumn{4}{|c|}{ Product types } \\
\hline & & Non-durable & Semi-durable & Durable & Services \\
\hline \multicolumn{6}{|l|}{$\Sigma \bar{\pi}_{j t}$ (sectoral price trends) } \\
\hline Avg. $\beta_{1} \mid \beta_{1}>0$ & $\begin{array}{l}1.37 \\
(0.94)\end{array}$ & $\begin{array}{l}1.38 \\
(0.96)\end{array}$ & $\begin{array}{l}1.70 \\
(0.75)\end{array}$ & $\begin{array}{l}1.45 \\
(0.92)\end{array}$ & $\begin{array}{l}1.08 \\
(1.00)\end{array}$ \\
\hline Avg. $\beta_{1} \mid \beta_{1}>1$ & $\begin{array}{l}1.58 \\
(0.47)\end{array}$ & $\begin{array}{l}1.61 \\
(0.53)\end{array}$ & $\begin{array}{l}2.09 \\
(0.47)\end{array}$ & $\begin{array}{l}1.69 \\
(0.36)\end{array}$ & $\begin{array}{l}1.18 \\
(0.39)\end{array}$ \\
\hline Avg. $\beta_{1} \mid \beta_{1}<0$ & $\begin{array}{l}-2.78 \\
(0.03)\end{array}$ & $(0.00)$ & $\begin{array}{l}-1.30 \\
(0.09)\end{array}$ & $\begin{array}{l}-5.34 \\
(0.08)\end{array}$ & $(0.00)$ \\
\hline \multicolumn{6}{|c|}{$\Sigma \hat{\pi}_{j t}^{+}$(positive sector-specific shocks) } \\
\hline Avg. $\beta_{2} \mid \beta_{2}>0$ & $\begin{array}{c}1.40 \\
(0.72)\end{array}$ & $\begin{array}{c}1.51 \\
(0.90)\end{array}$ & $\begin{array}{l}1.40 \\
(0.70)\end{array}$ & $\begin{array}{l}1.49 \\
(0.52)\end{array}$ & $\begin{array}{c}0.76 \\
(0.34)\end{array}$ \\
\hline Avg. $\beta_{2} \mid \beta_{2}>1$ & $\begin{array}{c}1.77 \\
(0.30)\end{array}$ & $\begin{array}{l}1.76 \\
(0.45)\end{array}$ & $\begin{array}{c}1.92 \\
(0.14)\end{array}$ & $\begin{array}{c}1.91 \\
(0.17)\end{array}$ & $\begin{array}{l}1.28 \\
(0.03)\end{array}$ \\
\hline Avg. $\beta_{2} \mid \beta_{2}<0$ & $\begin{array}{l}-0.50 \\
(0.02)\end{array}$ & $\begin{array}{l}-0.22 \\
(0.02)\end{array}$ & $\begin{array}{l}-1.46 \\
(0.10)\end{array}$ & $\begin{array}{l}-0.48 \\
(0.00)\end{array}$ & $\begin{array}{l}-0.37 \\
(0.01)\end{array}$ \\
\hline \multicolumn{6}{|c|}{$\Sigma \hat{\pi}_{j t}^{-}$(negative sector-specific shocks) } \\
\hline Avg. $\beta_{3} \mid \beta_{3}>0$ & $\begin{array}{c}1.28 \\
(0.71)\end{array}$ & $\begin{array}{l}1.09 \\
(0.72)\end{array}$ & $\begin{array}{c}1.04 \\
(0.44)\end{array}$ & $\begin{array}{c}1.71 \\
(0.66)\end{array}$ & $\begin{array}{l}1.66 \\
(0.95)\end{array}$ \\
\hline Avg. $\beta_{3} \mid \beta_{3}>1$ & $\begin{array}{c}1.72 \\
(0.32)\end{array}$ & $\begin{array}{l}1.72 \\
(0.33)\end{array}$ & $\begin{array}{l}1.77 \\
(0.09)\end{array}$ & $\begin{array}{c}1.76 \\
(0.31)\end{array}$ & $\begin{array}{l}1.68 \\
(0.48)\end{array}$ \\
\hline Avg. $\beta_{3} \mid \beta_{3}<0$ & $\begin{array}{l}-0.31 \\
(0.01)\end{array}$ & $\begin{array}{l}-0.32 \\
(0.00)\end{array}$ & $\begin{array}{l}-0.27 \\
(0.07)\end{array}$ & $\begin{array}{l}-0.33 \\
(0.00)\end{array}$ & $\begin{array}{c}0.00 \\
(0.00)\end{array}$ \\
\hline \multicolumn{6}{|c|}{$\Sigma \hat{\pi}_{j t}^{+}, \Sigma \hat{\pi}_{j t}^{-}$(positive and negative sector-specific shocks) } \\
\hline Avg. $\beta_{2}-\beta_{3} \mid \beta_{2}-\beta_{3}>0$ & $\begin{array}{c}0.95 \\
(0.26)\end{array}$ & $\begin{array}{c}1.09 \\
(0.38)\end{array}$ & $\begin{array}{c}1.04 \\
(0.43)\end{array}$ & $\begin{array}{c}0.35 \\
(0.00)\end{array}$ & $\begin{array}{c}0.39 \\
(0.00)\end{array}$ \\
\hline Avg. $\beta_{2}-\beta_{3} \mid \beta_{2}-\beta_{3}<0$ & $\begin{array}{l}-0.98 \\
(0.24)\end{array}$ & $\begin{array}{l}-0.67 \\
(0.22)\end{array}$ & $\begin{array}{l}-1.80 \\
(0.10)\end{array}$ & $\begin{array}{l}-0.94 \\
(0.13)\end{array}$ & $\begin{array}{l}-1.29 \\
(0.59)\end{array}$ \\
\hline Avg. $\beta_{2}-\beta_{3} \mid \beta_{2}-\beta_{3} \neq 0$ & $\begin{array}{c}0.03 \\
(0.41)\end{array}$ & $\begin{array}{c}0.44 \\
(0.52)\end{array}$ & $\begin{array}{c}0.39 \\
(0.54)\end{array}$ & $\begin{array}{l}-0.34 \\
(0.13)\end{array}$ & $\begin{array}{l}-1.24 \\
(0.28)\end{array}$ \\
\hline \multicolumn{6}{|c|}{$\bar{\pi}_{j t}\left(\right.$ sectoral inflation trend upper threshold $\left.\theta^{+}\right)$} \\
\hline Avg. $\delta_{1}^{+} \mid \delta_{1}^{+}>0$ & $\begin{array}{c}6.85 \\
(0.22)\end{array}$ & $\begin{array}{c}5.56 \\
(0.35)\end{array}$ & $\begin{array}{l}12.78 \\
(0.18)\end{array}$ & $\begin{array}{l}11.52 \\
(0.02)\end{array}$ & $\begin{array}{l}1.05 \\
(0.05)\end{array}$ \\
\hline Avg. $\delta_{1}^{+} \mid \delta_{1}^{+}<0$ & $\begin{array}{l}-11.93 \\
(0.40)\end{array}$ & $\begin{array}{l}-8.02 \\
(0.23)\end{array}$ & $\begin{array}{l}-8.68 \\
(0.34)\end{array}$ & $\begin{array}{l}-24.70 \\
(0.74)\end{array}$ & $\begin{array}{l}-5.19 \\
(0.62)\end{array}$ \\
\hline \multicolumn{6}{|c|}{$\bar{\pi}_{j t}\left(\right.$ sectoral inflation trend lower threshold $\left.\theta^{-}\right)$} \\
\hline Avg. $\delta_{1}^{-} \mid \delta_{1}^{-}>0$ & $\begin{array}{c}7.29 \\
(0.13)\end{array}$ & $\begin{array}{c}4.29 \\
(0.15)\end{array}$ & $\begin{array}{c}7.97 \\
(0.14)\end{array}$ & $\begin{array}{l}18.91 \\
(0.18)\end{array}$ & $\begin{array}{l}14.22 \\
(0.00)\end{array}$ \\
\hline Avg. $\delta_{1}^{-} \mid \delta_{1}^{-}<0$ & $\begin{array}{l}-16.98 \\
(0.55)\end{array}$ & $\begin{array}{l}-12.98 \\
(0.42)\end{array}$ & $\begin{array}{l}-20.99 \\
(0.67)\end{array}$ & $\begin{array}{l}-23.16 \\
(0.63)\end{array}$ & $\begin{array}{l}-17.84 \\
(0.79)\end{array}$ \\
\hline Avg. $\sigma_{\varepsilon}$ & 13.54 & 14.98 & 15.76 & 12.86 & 7.73 \\
\hline Avg. $\theta_{i t}^{+}-\mu_{i}$ & 24.77 & 25.79 & 31.17 & 22.63 & 19.29 \\
\hline Avg. $\theta_{i t}^{-}-\mu_{i}$ & -29.82 & -30.12 & -35.77 & -25.71 & -29.69 \\
\hline Avg. fit (positive) & 0.81 & 0.81 & 0.81 & 0.81 & 0.81 \\
\hline Avg. fit (negative) & 0.64 & 0.66 & 0.61 & 0.56 & 0.67 \\
\hline Sectors & 66 & 38 & 11 & 10 & 7 \\
\hline Observations & $3,128,862$ & $2,132,911$ & 469,807 & 379,643 & 146,501 \\
\hline
\end{tabular}

Note: See Table 3. 
Table 18: Estimates of desired price equation (average price change instead of sectoral inflation)

\begin{tabular}{|c|c|c|c|c|c|}
\hline & \multirow[b]{2}{*}{ All sectors } & \multicolumn{4}{|c|}{ Product types } \\
\hline & & Non-durable & Semi-durable & Durable & Services \\
\hline \multicolumn{6}{|c|}{$\overline{\Sigma \triangle p_{i j t}(\text { sectoral price trends) }}$} \\
\hline \multirow[t]{2}{*}{ Avg. $\beta_{1} \mid \beta_{1}>0$} & 1.02 & 0.95 & 1.02 & 0.90 & 1.35 \\
\hline & $(0.97)$ & $(1.00)$ & $(1.00)$ & $(0.95)$ & $(0.91)$ \\
\hline \multirow{2}{*}{ Avg. $\beta_{1} \mid \beta_{1}>1$} & 1.34 & 1.22 & 1.48 & 1.32 & 1.46 \\
\hline & $(0.26)$ & $(0.17)$ & $(0.22)$ & $(0.09)$ & $(0.67)$ \\
\hline \multirow{2}{*}{ Avg. $\beta_{1} \mid \beta_{1}<0$} & - & - & - & - & - \\
\hline & $(0.00)$ & $(0.00)$ & $(0.00)$ & $(0.00)$ & $(0.00)$ \\
\hline \multicolumn{6}{|c|}{$\overline{\triangle p}_{i j t}$ (sectoral inflation trend upper threshold $\theta^{+}$) } \\
\hline \multirow{2}{*}{ Avg. $\delta_{1}^{+} \mid \delta_{1}^{+}>0$} & 1.97 & 1.12 & - & - & 2.04 \\
\hline & $(0.05)$ & $(0.01)$ & $(0.00)$ & $(0.00)$ & $(0.24)$ \\
\hline \multirow{2}{*}{ Avg. $\delta_{1}^{+} \mid \delta_{1}^{+}<0$} & -5.59 & -5.17 & -4.74 & -6.43 & -6.58 \\
\hline & $(0.71)$ & $(0.82)$ & $(0.62)$ & $(0.74)$ & $(0.43)$ \\
\hline \multicolumn{6}{|c|}{$\overline{\triangle p}_{i j t}$ (sectoral inflation trend lower threshold $\theta^{-}$) } \\
\hline \multirow[t]{2}{*}{ Avg. $\delta_{1}^{-} \mid \delta_{1}^{-}>0$} & 2.43 & 1.95 & 0.19 & 3.47 & 3.66 \\
\hline & $(0.06)$ & $(0.00)$ & $(0.00)$ & $(0.10)$ & $(0.23)$ \\
\hline \multirow[t]{2}{*}{ Avg. $\delta_{1}^{-} \mid \delta_{1}^{-}<0$} & -4.65 & -4.47 & -4.27 & -4.05 & -6.15 \\
\hline & $(0.69)$ & $(0.82)$ & $(0.62)$ & $(0.64)$ & $(0.44)$ \\
\hline Avg. $\sigma_{\varepsilon}$ & 13.94 & 15.36 & 16.04 & 12.62 & 10.28 \\
\hline Avg. $\theta_{i t}^{+}-\mu_{i}$ & 25.66 & 26.87 & 30.80 & 21.76 & 23.36 \\
\hline Avg. $\theta_{i t}^{-}-\mu_{i}$ & -30.69 & -29.89 & -36.31 & -25.58 & -34.68 \\
\hline Avg. fit (positive) & 0.81 & 0.79 & 0.82 & 0.82 & 0.82 \\
\hline Avg. fit (negative) & 0.61 & 0.61 & 0.57 & 0.60 & 0.64 \\
\hline Sectors & 67 & 38 & 11 & 10 & 8 \\
\hline Observations & $3,157,816$ & $2,132,911$ & 469,807 & 379,643 & 175,455 \\
\hline
\end{tabular}

Note: See Table 3.

Table 19: Counterfactual predictions (full estimation range)

\begin{tabular}{lrrrrrr}
\hline & Data & Model & $\pi_{t}=0^{(1)}$ & $\pi_{t}=0^{(2)}$ & $\pi_{j t}=0^{(1)}$ & $\pi_{j t}=0^{(2)}$ \\
\hline All sectors & 66.4 & 66.1 & 62.6 & 57.2 & 63.8 & 61.8 \\
Non-durable & 63.3 & 63.0 & 58.9 & 54.7 & 61.2 & 58.9 \\
Semi-durable & 64.2 & 63.7 & 62.8 & 59.2 & 63.2 & 64.6 \\
Durable & 64.2 & 64.2 & 60.4 & 48.1 & 63.4 & 63.4 \\
Services & 78.2 & 77.7 & 74.7 & 71.8 & 71.5 & 66.2 \\
\hline
\end{tabular}

Note: See Table 5 .

Table 20: Counterfactual predictions (aggregate price level and personal consumption)

Note: See Table 5 .

\begin{tabular}{lrrrrrr}
\hline & Data & Model & $\pi_{t}=0^{(1)}$ & $\pi_{t}=0^{(2)}$ & $\pi_{j t}=0^{(1)}$ & $\pi_{j t}=0^{(2)}$ \\
\hline All sectors & 66.4 & 66.1 & 62.5 & 57.7 & 61.7 & 58.9 \\
Non-durable & 63.3 & 62.8 & 59.0 & 54.8 & 59.4 & 55.0 \\
Semi-durable & 64.2 & 64.0 & 62.7 & 59.4 & 60.9 & 62.6 \\
Durable & 64.2 & 64.0 & 62.2 & 53.8 & 61.9 & 61.5 \\
Services & 78.2 & 78.0 & 71.9 & 68.3 & 68.4 & 64.9 \\
\hline See Table 5 & & & & & &
\end{tabular}


Table 21: Counterfactual predictions (HP filter for calculating the trend)

\begin{tabular}{lrrrrrr}
\hline & Data & Model & $\pi_{t}=0^{(1)}$ & $\pi_{t}=0^{(2)}$ & $\pi_{j t}=0^{(1)}$ & $\pi_{j t}=0^{(2)}$ \\
\hline All sectors & 66.4 & 65.9 & 60.0 & 47.7 & 61.4 & 51.4 \\
Non-durable & 63.3 & 62.9 & 55.7 & 51.5 & 59.9 & 57.1 \\
Semi-durable & 64.2 & 63.8 & 59.9 & 55.1 & 61.8 & 60.4 \\
Durable & 64.2 & 63.5 & 58.7 & 29.7 & 61.4 & 44.2 \\
Services & 78.2 & 77.6 & 73.0 & 50.8 & 65.4 & 38.1 \\
\hline
\end{tabular}

Note: See Table 5 .

Table 22: Counterfactual predictions (average price change instead of sectoral inflation)

\begin{tabular}{lrrrrrr}
\hline & Data & Model & $\pi_{t}=0^{(1)}$ & $\pi_{t}=0^{(2)}$ & $\pi_{j t}=0^{(1)}$ & $\pi_{j t}=0^{(2)}$ \\
\hline All sectors & 66.4 & 66.0 & 60.7 & 55.5 & 62.3 & 56.7 \\
Non-durable & 63.3 & 62.8 & 58.4 & 53.9 & 58.4 & 51.1 \\
Semi-durable & 64.2 & 63.8 & 58.2 & 54.6 & 62.2 & 60.7 \\
Durable & 64.2 & 63.7 & 58.3 & 50.7 & 64.1 & 63.7 \\
Services & 78.2 & 78.0 & 70.6 & 64.8 & 70.9 & 62.7 \\
\hline
\end{tabular}

Note: See Table 5. 


\section{Swiss National Bank Working Papers published since 2004:}

2004-1 Samuel Reynard: Financial Market Participation and the Apparent Instability of Money Demand

2004-2 Urs W. Birchler and Diana Hancock: What Does the Yield on Subordinated Bank Debt Measure?

2005-1 Hasan Bakhshi, Hashmat Khan and Barbara Rudolf: The Phillips curve under state-dependent pricing

2005-2 Andreas M. Fischer: On the Inadequacy of Newswire Reports for Empirical Research on Foreign Exchange Interventions

2006-1 Andreas M. Fischer: Measuring Income Elasticity for Swiss Money Demand: What do the Cantons say about Financial Innovation?

2006-2 Charlotte Christiansen and Angelo Ranaldo: Realized Bond-Stock Correlation: Macroeconomic Announcement Effects

2006-3 Martin Brown and Christian Zehnder: Credit Reporting, Relationship Banking, and Loan Repayment

2006-4 Hansjörg Lehmann and Michael Manz: The Exposure of Swiss Banks to Macroeconomic Shocks - an Empirical Investigation

2006-5 Katrin Assenmacher-Wesche and Stefan Gerlach: Money Growth, Output Gaps and Inflation at Low and High Frequency: Spectral Estimates for Switzerland

2006-6 Marlene Amstad and Andreas M. Fischer: Time-Varying Pass-Through from Import Prices to Consumer Prices: Evidence from an Event Study with Real-Time Data

2006-7 Samuel Reynard: Money and the Great Disinflation

2006-8 Urs W. Birchler and Matteo Facchinetti: Can bank supervisors rely on market data? A critical assessment from a Swiss perspective

2006-9 Petra Gerlach-Kristen: A Two-Pillar Phillips Curve for Switzerland

2006-10 Kevin J. Fox and Mathias Zurlinden: On Understanding Sources of Growth and Output Gaps for Switzerland

2006-11 Angelo Ranaldo: Intraday Market Dynamics Around Public Information Arrivals

2007-1 Andreas M. Fischer, Gulzina Isakova and Ulan Termechikov: Do FX traders in Bishkek have similar perceptions to their London colleagues? Survey evidence of market practitioners' views 
2007-2 Ibrahim Chowdhury and Andreas Schabert: Federal Reserve Policy viewed through a Money Supply Lens

2007-3 Angelo Ranaldo: Segmentation and Time-of-Day Patterns in Foreign Exchange Markets

2007-4 Jürg M. Blum: Why ‘Basel II' May Need a Leverage Ratio Restriction

2007-5 Samuel Reynard: Maintaining Low Inflation: Money, Interest Rates, and Policy Stance

2007-6 Rina Rosenblatt-Wisch: Loss Aversion in Aggregate Macroeconomic Time Series

2007-7 Martin Brown, Maria Rueda Maurer, Tamara Pak and Nurlanbek Tynaev: Banking Sector Reform and Interest Rates in Transition Economies: Bank-Level Evidence from Kyrgyzstan

2007-8 Hans-Jürg Büttler: An Orthogonal Polynomial Approach to Estimate the Term Structure of Interest Rates

2007-9 Raphael Auer: The Colonial Origins Of Comparative Development: Comment. A Solution to the Settler Mortality Debate

2007-10 Franziska Bignasca and Enzo Rossi: Applying the Hirose-Kamada filter to Swiss data: Output gap and exchange rate pass-through estimates

2007-11 Angelo Ranaldo and Enzo Rossi: The reaction of asset markets to Swiss National Bank communication

2007-12 Lukas Burkhard and Andreas M. Fischer: Communicating Policy Options at the Zero Bound

2007-13 Katrin Assenmacher-Wesche, Stefan Gerlach, and Toshitaka Sekine: Monetary Factors and Inflation in Japan

2007-14 Jean-Marc Natal and Nicolas Stoffels: Globalization, markups and the natural rate of interest

2007-15 Martin Brown, Tullio Jappelli and Marco Pagano: Information Sharing and Credit: Firm-Level Evidence from Transition Countries

2007-16 Andreas M. Fischer, Matthias Lutz and Manuel Wälti: Who Prices Locally? Survey Evidence of Swiss Exporters

2007-17 Angelo Ranaldo and Paul Söderlind: Safe Haven Currencies 
2008-1 Martin Brown and Christian Zehnder: The Emergence of Information Sharing in Credit Markets

2008-2 Yvan Lengwiler and Carlos Lenz: Intelligible Factors for the Yield Curve

2008-3 Katrin Assenmacher-Wesche and M. Hashem Pesaran: Forecasting the Swiss Economy Using VECX* Models: An Exercise in Forecast Combination Across Models and Observation Windows

2008-4 Maria Clara Rueda Maurer: Foreign bank entry, institutional development and credit access: firm-level evidence from 22 transition countries

2008-5 Marlene Amstad and Andreas M. Fischer: Are Weekly Inflation Forecasts Informative?

2008-6 Raphael Auer and Thomas Chaney: Cost Pass Through in a Competitive Model of Pricing-to-Market

2008-7 Martin Brown, Armin Falk and Ernst Fehr: Competition and Relational Contracts: The Role of Unemployment as a Disciplinary Device

2008-8 Raphael Auer: The Colonial and Geographic Origins of Comparative Development

2008-9 Andreas M. Fischer and Angelo Ranaldo: Does FOMC News Increase Global FX Trading?

2008-10 Charlotte Christiansen and Angelo Ranaldo: Extreme Coexceedances in New EU Member States' Stock Markets

2008-11 Barbara Rudolf and Mathias Zurlinden: Measuring capital stocks and capital services in Switzerland

2008-12 Philip Sauré: How to Use Industrial Policy to Sustain Trade Agreements

2008-13 Thomas Bolli and Mathias Zurlinden: Measuring growth of labour quality and the quality-adjusted unemployment rate in Switzerland

2008-14 Samuel Reynard: What Drives the Swiss Franc?

2008-15 Daniel Kaufmann: Price-Setting Behaviour in Switzerland - Evidence from CPI Micro Data

2008-16 Katrin Assenmacher-Wesche and Stefan Gerlach: Financial Structure and the Impact of Monetary Policy on Asset Prices

2008-17 Ernst Fehr, Martin Brown and Christian Zehnder: On Reputation: A Microfoundation of Contract Enforcement and Price Rigidity 
2008-18 Raphael Auer and Andreas M. Fischer: The Effect of Low-Wage Import Competition on U.S. Inflationary Pressure

2008-19 Christian Beer, Steven Ongena and Marcel Peter: Borrowing in Foreign Currency: Austrian Households as Carry Traders

2009-1 Thomas Bolli and Mathias Zurlinden: Measurement of labor quality growth caused by unobservable characteristics

2009-2 Martin Brown, Steven Ongena and Pinar Yeșin: Foreign Currency Borrowing by Small Firms

2009-3 Matteo Bonato, Massimiliano Caporin and Angelo Ranaldo: Forecasting realized (co)variances with a block structure Wishart autoregressive model

2009-4 Paul Söderlind: Inflation Risk Premia and Survey Evidence on Macroeconomic Uncertainty

2009-5 Christian Hott: Explaining House Price Fluctuations

2009-6 Sarah M. Lein and Eva Köberl: Capacity Utilisation, Constraints and Price Adjustments under the Microscope

2009-7 Philipp Haene and Andy Sturm: Optimal Central Counterparty Risk Management

2009-8 Christian Hott: Banks and Real Estate Prices

2009-9 Terhi Jokipii and Alistair Milne: Bank Capital Buffer and Risk Adjustment Decisions

2009-10 Philip Sauré: Bounded Love of Variety and Patterns of Trade

2009-11 Nicole Allenspach: Banking and Transparency: Is More Information Always Better?

2009-12 Philip Sauré and Hosny Zoabi: Effects of Trade on Female Labor Force Participation

2009-13 Barbara Rudolf and Mathias Zurlinden: Productivity and economic growth in Switzerland 1991-2005

2009-14 Sébastien Kraenzlin and Martin Schlegel: Bidding Behavior in the SNB's Repo Auctions

2009-15 Martin Schlegel and Sébastien Kraenzlin: Demand for Reserves and the Central Bank's Management of Interest Rates

2009-16 Carlos Lenz and Marcel Savioz: Monetary determinants of the Swiss franc 
2010-1 Charlotte Christiansen, Angelo Ranaldo and Paul Söderlind: The Time-Varying Systematic Risk of Carry Trade Strategies

2010-2 Daniel Kaufmann: The Timing of Price Changes and the Role of Heterogeneity

2010-3 Loriano Mancini, Angelo Ranaldo and Jan Wrampelmeyer: Liquidity in the Foreign Exchange Market: Measurement, Commonality, and Risk Premiums

2010-4 Samuel Reynard and Andreas Schabert: Modeling Monetary Policy

2010-5 Pierre Monnin and Terhi Jokipii: The Impact of Banking Sector Stability on the Real Economy

2010-6 Sébastien Kraenzlin and Thomas Nellen: Daytime is money

2010-7 Philip Sauré: Overreporting 0il Reserves

2010-8 Elizabeth Steiner: Estimating a stock-flow model for the Swiss housing market

2010-9 Martin Brown, Steven Ongena, Alexander Popov, and Pinar Yeșin: Who Needs Credit and Who Gets Credit in Eastern Europe?

2010-10 Jean-Pierre Danthine and André Kurmann: The Business Cycle Implications of Reciprocity in Labor Relations

2010-11 Thomas Nitschka: Momentum in stock market returns: Implications for risk premia on foreign currencies

2010-12 Petra Gerlach-Kristen and Barbara Rudolf: Macroeconomic and interest rate volatility under alternative monetary operating procedures

2010-13 Raphael Auer: Consumer Heterogeneity and the Impact of Trade Liberalization: How Representative is the Representative Agent Framework?

2010-14 Tommaso Mancini Griffoli and Angelo Ranaldo: Limits to arbitrage during the crisis: funding liquidity constraints and covered interest parity

2010-15 Jean-Marc Natal: Monetary Policy Response to Oil Price Shocks

2010-16 Kathrin Degen and Andreas M. Fischer: Immigration and Swiss House Prices

2010-17 Andreas M. Fischer: Immigration and large banknotes

2010-18 Raphael Auer: Are Imports from Rich Nations Deskilling Emerging Economies? Human Capital and the Dynamic Effects of Trade 
2010-19 Jean-Pierre Danthine and John B. Donaldson: Executive Compensation: A General Equilibrium Perspective

2011-1 Thorsten Beck and Martin Brown: Which Households Use Banks? Evidence from the Transition Economies

2011-2 Martin Brown, Karolin Kirschenmann and Steven Ongena: Foreign Currency Loans Demand or Supply Driven?

2011-3 Victoria Galsband and Thomas Nitschka: Foreign currency returns and systematic risks

2011-4 Francis Breedon and Angelo Ranaldo: Intraday patterns in FX returns and order flow

2011-5 Basil Guggenheim, Sébastien Kraenzlin and Silvio Schumacher: Exploring an uncharted market: Evidence on the unsecured Swiss franc money market

2011-6 Pamela Hall: Is there any evidence of a Greenspan put?

2011-7 Daniel Kaufmann and Sarah Lein: Sectoral Inflation Dynamics, Idiosyncratic Shocks and Monetary Policy

2011-8 Iva Cecchin: Mortgage Rate Pass-Through in Switzerland

2011-9 Raphael A. Auer, Kathrin Degen and Andreas M. Fischer: Low-Wage Import Competition, Inflationary Pressure, and Industry Dynamics in Europe

2011-10 Raphael A. Auer and Philip Sauré: Spatial Competition in Quality, Demand-Induced Innovation, and Schumpeterian Growth

2011-11 Massimiliano Caporin , Angelo Ranaldo and Paolo Santucci de Magistris: On the Predictability of Stock Prices: a Case for High and Low Prices

2011-12 Jürg Mägerle and Thomas Nellen: Interoperability between central counterparties

2011-13 Sylvia Kaufmann: K-state switching models with endogenous transition distributions

2011-14 Sébastien Kraenzlin and Benedikt von Scarpatetti: Bargaining Power in the Repo Market

2012-01 Raphael A. Auer: Exchange Rate Pass-Through, Domestic Competition, and Inflation: Evidence from the 2005/08 Revaluation of the Renminbi

2012-02 Signe Krogstrup, Samuel Reynard and Barbara Sutter: Liquidity Effects of Quantitative Easing on Long-Term Interest Rates 
2012-03 Matteo Bonato, Massimiliano Caporin and Angelo Ranaldo: Risk spillovers in international equity portfolios

2012-04 Thomas Nitschka: Banking sectors' international interconnectedness: Implications for consumption risk sharing in Europe

2012-05 Martin Brown, Steven Ongena and Pinar Yeşin: Information Asymmetry and Foreign Currency Borrowing by Small Firms

2012-06 Philip Sauré and Hosny Zoabi: Retirement Age across Countries: The Role of Occupations

2012-07 Christian Hott and Terhi Jokipii: Housing Bubbles and Interest Rates

2012-08 Romain Baeriswyl and Camille Cornand: Reducing overreaction to central bank's disclosures: theory and experiment

2012-09 Bo E. Honoré, Daniel Kaufmann and Sarah Lein: Asymmetries in Price-Setting Behavior: New Microeconometric Evidence from Switzerland 
Swiss National Bank Working Papers are also available at www.snb.ch, section Publications/Research Subscriptions or individual issues can be ordered at Swiss National Bank, Fraumünsterstrasse 8, CH-8022 Zurich, fax+41 4463181 14, E-mail library@snb.ch 